\title{
Determinants of consulting the general practitioner
}

Citation for published version (APA):

van der Kar, A. G. (1992). Determinants of consulting the general practitioner. [Doctoral Thesis, Maastricht University]. Rijksuniversiteit Limburg. https://doi.org/10.26481/dis.19921001ak

Document status and date:

Published: 01/01/1992

DOI:

10.26481/dis.19921001ak

Document Version:

Publisher's PDF, also known as Version of record

\section{Please check the document version of this publication:}

- A submitted manuscript is the version of the article upon submission and before peer-review. There can be important differences between the submitted version and the official published version of record.

People interested in the research are advised to contact the author for the final version of the publication, or visit the DOI to the publisher's website.

- The final author version and the galley proof are versions of the publication after peer review.

- The final published version features the final layout of the paper including the volume, issue and page numbers.

Link to publication

\footnotetext{
General rights rights.

- You may freely distribute the URL identifying the publication in the public portal. please follow below link for the End User Agreement:

www.umlib.nl/taverne-license

Take down policy

If you believe that this document breaches copyright please contact us at:

repository@maastrichtuniversity.nl

providing details and we will investigate your claim.
}

Copyright and moral rights for the publications made accessible in the public portal are retained by the authors and/or other copyright owners and it is a condition of accessing publications that users recognise and abide by the legal requirements associated with these

- Users may download and print one copy of any publication from the public portal for the purpose of private study or research.

- You may not further distribute the material or use it for any profit-making activity or commercial gain

If the publication is distributed under the terms of Article $25 \mathrm{fa}$ of the Dutch Copyright Act, indicated by the "Taverne" license above, 


\section{DETERMINANTS OF CONSULTING THE GENERAL PRACTITIONER}

\section{PROEFSCHRIFT}

ter verkrijging van de graad van doctor

aan de Rijksuniversiteit Limburg te Maastricht, op gezag van de Rector Magnificus, Prof. Mr. M.J. Cohen,

volgens het besluit van het College van Dekanen, in het openbaar te verdedigen op donderdag, 1 oktober 1992 om 16.00 uur

door

Angélique Gabriëlla Alberta van de Kar - Huisman

geboren te Echt op 2 oktober 1961 


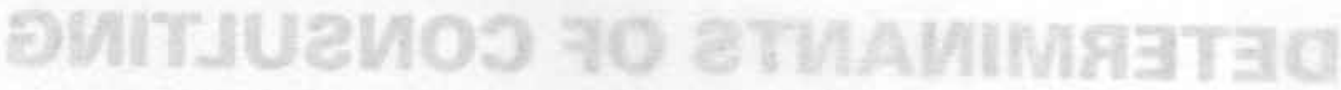

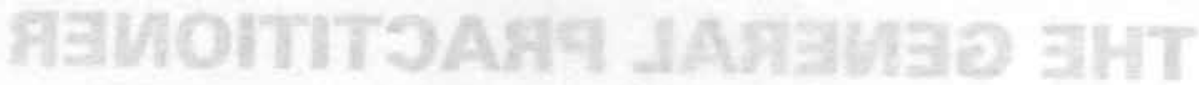




\section{DETERMINANTS OF CONSULTING THE GENERAL PRACTITIONER}

\section{PROEFSCHRIFT}

ter verkrijging van de graad van doctor aan de Rijksuniversiteit Limburg te Maastricht, op gezag van de Rector Magnificus, Prof. Mr. M.J. Cohen, volgens het besluit van het College van Dekanen, in het openbaar te verdedigen op donderdag, 1 oktober 1992 om 16.00 uur

door

Angelique Gabrięlia Alberta van de Kar * Huisman

geboren te Echt op 2 oktober 1961 


\section{Promotores:}

Prof. Dr. G.J. Kok

Prof. Dr. J.A. Knottnerus

\section{Co-Promoter:}

Dr. R.M. Meertens

\section{Beoordelingscommissie:}

Prof. Dr. H. Philipsen (Voorzitter)

Prof. Dr. Mr. R.P.T.M. Grol

Prof. Dr. P.D. Mullen (University of Texas, Houston)

Dr. N.K. de Vries (Universiteit van Amsterdam)

Prof. Dr. J. van der Zee

CIP-DATA KONINKLIJKE BIBLIOTHEEK, DEN HAAG

Kar, Angélique van de

Determinants of consulting the general practitioner / Angélique van de Kar; [ill. by the author]. - [S.I.: s.n.]. - III.

Thesis Maastricht. - With ref. - With summary in Dutch.

ISBN 90 - $9005380-8$

NUGI $735 / 741$

Subject headings: general practitioners.

Cover design: Staff of Aesculapius

Symbolizing the entwining of Health Education and General Practice.

Support: Roland van de Kar

Frank van de Kar Jo Levels 
Aan Roland,

my V.I.Paranimf. 



\section{PREFACE}

This dissertation is more than writing about research, it also covers an important part of my life. In that part many people have been involved. Without saying a general 'thank you' to everybody who helped me during this period, I would like to express my gratitude to some personally.

Ree Meertens, looking at this dissertation it seems so smooth and structured. You know that it wasn't the case. I remember the times that all the white space at drafts were filled completely with your comments, but I have learned to appreciate your commenting enormously.

Gerjo Kok, you were the one who contracted me to start the research. Despite your precious time during the research, I learned from you what Health Education should be in theory and in practice. I am building on it daily in my work at the Public Health Department.

André Knottnerus, the research was going on quite some time when you became involved in the research. However, your contribution was very valuable for the research and for me. My knowledge about General Practice, learned from you, is also useful in my work today with general practitioners in Midden-Limburg.

Patricia Mullen, your contribution was limited to two weeks a year. But your support has become very precious to me. I have learned you as a person with much expertise but also as a caring friend.

This research was a co-production of the Department of Health Education and the Department of General Practice. The members of these departments have given me the support needed to go on all these years. At the department of Health Education it was easy to find two perfect paranimfen for the occasion. Patricia van Assema, 'room-mate' at the department and special friend since years, and Dirk-Jan den Boer, who supported me enormously during my 'statistic phase'. Paranimfen with whom I could discuss the good but especially the hard times in 'research life'.

This research could only be executed with the help of the eight general practices. Despite the list I would like to thank the general practitioners van de Voort and Brouwers in Hoensbroek; Eijck, Muris, Winten-Huisman and van Leeuwen in Neerbeek; van der Grinten, Muris, Crebolder, van Kessel and Heida in Venlo; Jochems and Boesten in Elsloo; Verheye and Hamers in Sittard; Hulshof. Panhuysen and Guldemond in Voerendaal; Schlösser, van Aubel and van Hooff in Heerlen; Hundscheid, Sijstermans and Zwanikken in Heerlen, and of course their assistants and patients.

During the writing of this dissertation I started to work as Health Educator at the Public Health Department Midden-Limburg in Roermond. There I got support from many people but I haven't told Ingeborg yet how stimulating her special way of support was to me.

While writing this dissertation I got 'foreign' help from Bob Wilkinson and 'family' help from Gerda Huisman who corrected my English properly.

I just want to say that doing research and writing a dissertation cannot be done all by yourself. The support from colleagues, family and friends, in many different ways, made this a 'mission possible'. 


\section{9}




\section{CONTENTS}

CHAPTER 1 OVERVIEW 13

General outline $\quad 14$

Dutch research on use of GP services 15

$\begin{array}{ll}\text { The Health Belief Model } & 16\end{array}$

$\begin{array}{ll}\text { Methods } & 19\end{array}$

Conclusions 20

Theoretical conclusions $\quad 20$

Practical conclusions $\quad 21$

Methodological conclusions $\quad 22$

Limitations 23

Final remarks $\quad 23$

References $\quad 24$

CHAPTER 2 WHY DO PATIENTS CONSULT THE GENERAL PRACTITIONER?

Determinants of their decision. 27

$\begin{array}{ll}\text { Introduction } & 28 \\ \text { Methods } & 28\end{array}$

$\begin{array}{ll}\text { Methods } & 28\end{array}$

The Health Belief Model $\quad 28$

Sample $\quad 29$

Questionnaires $\quad 30$

Statistical analysis $\quad 31$

$\begin{array}{ll}\text { Results } & 31\end{array}$

Background characteristics of analysis sample $\quad 32$

Decision to consult $\quad 32$

Discussion $\quad 34$

References $\quad 36$

CHAPTER 3 WORRY: A PARTICULAR DETERMINANT OF CONSULTATION ILLUMINATED $\quad 39$

Introduction 40

Method 42

Sample and procedure $\quad 42$

Questionnaires $\quad 42$

Determinants of worry $\quad 42$

Worry as a dependent variable $\quad 43$

Satisfaction with the discussion of worry 43

Statistical analysis $\quad 43$

Results $\quad 44$

Background characteristics of analysis sample 44

Perceptions concerning the complaint, care, and information $\quad 44$

Information from other people and mass media 46

Worry of the respondents before consulting the GP 46

Satisfaction with the discussion of worry 47

Hierarchical multiple regression analysis of general worry 47 
Effect of consulting the GP on worry

Effect of consultation and satisfaction with discussing worry 49

Discussion

References

CHAPTER 4 CHANGES IN PATIENTS' HEALTH BELIEFS AFTER CONSULTING THE GENERAL PRACTITIONER

Introduction

Method

Sample

Beliefs about complaint, care and information

Satisfaction with the consultation by the patient Results

Background characteristics of analysis sample 56

Effect of consulting the GP on health beliefs 57

Satisfaction after consultation $\quad 58$

Effect of consultation and general satisfaction 58

Discussion

References

CHAPTER 5 DETERMINANTS OF CONSULTING THE GENERAL PRACTITIONER AND PATIENTS' WORRY

An experimental and an observational study compared. 65

Introduction

Method of scenario study 1

Design 68

Subjects and procedure $\quad 68$

Manipulation of the independent variables 68

Intention to consult the GP and worry 68

Results and discussion scenario study $1 \quad 69$

Manipulation checks $\quad 69$

Analysis 69

Scenario study 2

Method of scenario study 2

Design $\quad 72$

Subjects and procedure $\quad 72$

Manipulation of the independent variables $\quad 72$

Dependent variables $\quad 72$

Results and discussion scenario study 2

Manipulation checks $\quad 73$

Analysis $\quad 73$

General Discussion $\quad 74$

References $\quad 76$ 
SAMENVATTING

$\begin{array}{lll}\text { ANNEX } 1 & \text { REFERENCES } & 87\end{array}$

$\begin{array}{lll}\text { ANNEX } 2 & \text { QUESTIONNAIRE I } & 91\end{array}$

$\begin{array}{lll}\text { ANNEX } 3 & \text { QUESTIONNAIRE } \| & 101\end{array}$

CURRICULUM VITAE 123 



\section{CHAPTER 1}

\section{OVERVIEW}

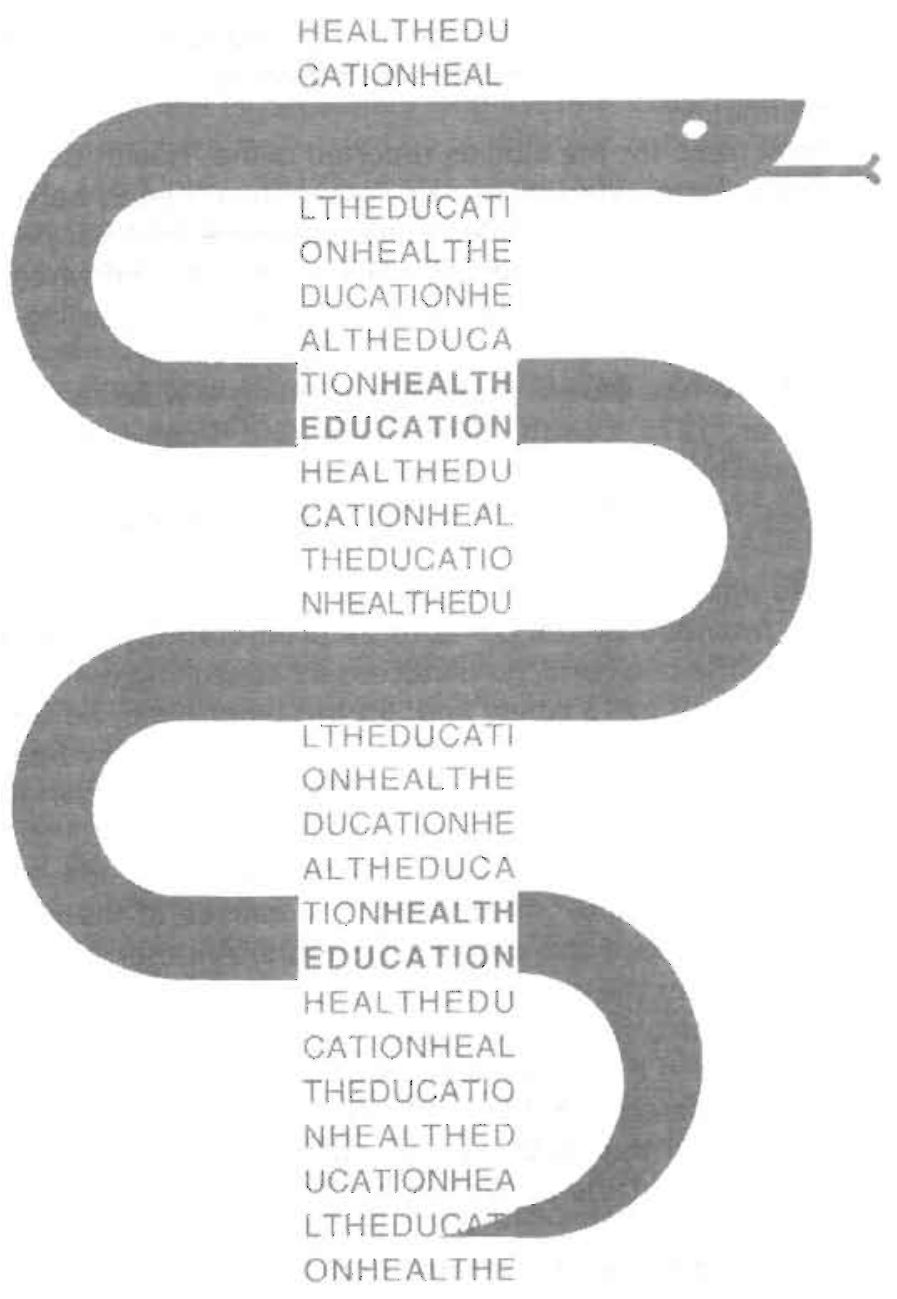




\section{GENERAL OUTILINE}

This thesis focuses on why patients consult their general practitioner (GP) about one complaint and not about another. The research reported here considered the impact of several factors on the decision to consult the GP. e.g. the patient's perception of the severity of the complaint, the patient's need for information on the complaint and the advice the patient gets from others. Special attention is paid to the factor 'worry': besides being an important determinant for GP consultation (de Jongh, 1987; Rieff \& Bremer, 1982) the worry patients experience is a factor which is increasingly perceived as a problem in the GP-patient interaction (Robinson \& Whitfield, 1987). Therefore, the factors that determine the worry patients experience are investigated as well.

In addition we try to gain some insight into how worry and other determinants of consulting the GP are influenced by a consultation. For example, it might be expected that a consultation reduces the patient's complaint related worry, or leads to a reduction in the patient's need for information.

The theoretical basis for the studies reported is the 'Health Belief Model' (HBM). The HBM was originally formulated to explain (preventive) health behaviour. The HBM assumes that the subjective health considerations determine whether people undertake a health related action, like consulting the GP. For example, the HBM considers the perceived, rather than the real, severity of the complaint to be the propelling force behind the health action.

Though the HBM has proven itself in explaining a wide range of health behaviours (Becker \& Maiman, 1975; Leavitt, 1979; Berkanovic, Telesky \& Reeder, 1981), a critical review of the model has resulted in some additions and slight changes to the model. Social factors and need for information especially seem not to be adequately covered by the HBM.

Research into people's decision to consult the GP is needed if effective use of the medical services provided by the GP is to be promoted (Lydeard \& Jones, 1989). Effective use means, on the one hand, no unnecessary consulting (which leads to medicalization, wasted GP time and extra costs) and, on the other hand, no unnecessary delay (which might lead to prolongation of the disease and more complex treatment). Such an effective use can only be reached by influencing in the desired direction the factors which determine consulting behaviour.

Furthermore this research may lead to more insight into the consultation itself, and to recommendations for the GP. Illuminating the causes of the patient's worry, for example, may be used to reduce this worry at its roots. Another aspect is the way the determinants are affected by the consultation. One would, for example, expect a considerable decrease in the perceived need for information from before to after consultation; if not, information exchange in the GP-patient interaction may be inadequate

Eventually the research might lead to advances in the theoretical domain. This thesis first examines whether the HBM is an adequate model to explain GP consultation Second, it investigates whether the predictive qualities of the HBM can be improved by adding new constructs

The research questions are formulated from the point of view of a health educator: the study into the determinants of GP consultation is seen as a necessary stage in developing an intervention aimed at promoting effective use of GP services; and in a way the GP-patient interaction is approached as a small health education intervention, which may be expected to have an effect on variables like worry or need for information. 
First, an overview is given of the research that is relevant for the question why people consult their GP. Then we elaborate the question why the HBM was chosen as the main theoretical framework for the studies reported here, and the model and a critical review leading to some adaptations of the model are presented afterwards. The remaining part of this overview describes the methods used to answer the research questions, the main results obtained, and the most important conclusions and recommendations which may be derived from the research.

\section{DUTCH RESEARCH ON USE OF GP SERVICES}

In the Netherlands, the role and the position of the GP in the health system is quite different from those in most other countries. This role is probably best described as the 'gatekeeper' of the health system. Patients, for example, cannot go to a specialist directly in general: they have to see their GP first as a rule, and are referred to the specialist only if the GP thinks this is necessary the system is comparable with that in the United Kingdom). Researchers have used quite different approaches to study the use of health services (cf. Mc Kinlay, 1972). In this paragraph we will discuss mainly Dutch research on the question why people consult their GP and why they consult the GP sometimes unnecessarily. In the following chapters relevant international literature will be discussed.

Before people decide whether or not to consult the GP, they have to go through several stages. First they have to recognize the symptoms; secondly, they have to interpret these symptoms as a health problem, and finally they have to make the decision to consult their GP for a health problem (Taylor, 1986; Hannay, 1979).

A study of Van de Lisdonk (1985), where the patients of four general practices were asked to fill in a diary on the complaints they experienced in a four-week period. showed that the GP was consulted for only about ten percent of the complaints. Van de Lisdonk wanted to gain insight in why some people repeatedly consult their GP about common complaints. Factor analysis on several aspects of the subjective experience of the complaints reported in the diary revealed two dimensions: 'perceived discomfort' and 'emotional stress'. Subjects who had, in foregoing years, repeatedly consulted the GP for new non-serious complaints, reported a higher degree of complaint related discomfort and emotional stress than those who had not such a history of medical consumption.

Results of the same author (1985) suggest that the main determinants of consulting the GP for new, non-serious complaints are: (1) the degree to which relief is expected from the GP in the case of minor complaints, and (2) the degree to which the complaints lasted over several days.

Effective use of GP-services is not only hampered by unnecessary consulting, but also by delaying a necessary consultation. This last topic was investigated in a study of Neven (1980). This author showed that socio-demographic variables of the patient (e.g. age, sex, familiarity with the complaint, cf. Cassee, 1973; Jessen, 1974), as well as characteristics of the complaint (e.g. painfulness, being a possible indicator of serious disease) and characteristics of the GP and/or the practice (e.g. age, open versus appointment consulting hours) were related to the extent to which patients delayed a consultation to the GP.

A closer analysis of the patients who postponed for complaints with a high degree of urgency longer than three weeks revealed that especially older patients (older than 46 years) were at risk to do so. Furthermore this category of patients seemed to mention relatively often as a reason for consulting the GP, that they had been advised to 
do so by others, or reported that they were consulting the GP because of some other complaint. These patients mentioned anxiety or inconvenience less frequently as reasons for consulting the GP. A study of Van der Zee (1982), a secondary analysis on data gathered in England and Wales, suggested that apart from the practice variables shown to be related to the patients consulting behaviour in Neven's study (1980)(the organization of the consulting hours) also the type of practice influenced the patients consulting behaviour. In solo-practices the patient initiated more contacts than in practices where their GP participated in a partnership.

Though only partially relevant for the present research project, it is interesting to consider the information the GP gets from the patient on his reasons for encounter. Hofmans-Okkes (1991) showed that GPs in general understand quite well why patients consult them. As far as there is a disagreement on the reason(s) for consulting between the GP and the patient, this disagreement concerns more often the fact that GPs observe too many reasons for encounter than too few. On the other hand Van der Grinten (1988) found that the contribution of patients to the consultation is often less than it could have been.

In general, the studies discussed in this paragraph did not use a specific theoretical framework as a guideline for research. Researchers followed an eclectic approach, and variables were selected from literature, models and/or intuition. However, more general models could be used as such a guideline. The four best known models are perhaps the Health Belief Model (HBM) (Becker, 1974; Rosenstock, 1974), the Protection Motivation Model (Rogers، 1983; Prentice-Dunn \& Rogers, 1986). Fishbein and Ajzen's model of reasoned action (Ajzen \& Fishbein, 1980; Oliver \& Berger, 1979), and the PRECEDE (Predisposing, Reinforcing, and Enabling Constructs in Educational/Environmental Diagnosis and Evaluation) framework (Green et al., 1980; Mullen et al., 1987).

These models have quite different backgrounds, and originally developed in quite different areas. Sometimes they overlap considerably (Cummings et al., 1980), but each model has its own advantages and disadvantages (cf. Oliver \& Berger, 1979; Mullen et al., 1987). In our study we have chosen the HBM as the leading model, mainly because of two, more practical reasons.

First, considering the variable of interest in this research ('consulting the GP'), we believed that the HBM would lead to more meaningful questions in the view of respondents than other models. Especially the Fishbein and Ajzen model sometimes leads to questions that are problematic to the respondents. Furthermore the study of Mullen and colleagues (1987) demonstrated that the HBM was more economically oriented than the PRECEDE framework and Fishbein and Ajzen's model, in terms of the questions employed.

We considered these advantages of the HBM important, given the type of respondents in our study with, for example, very different educational levels, and given that the time for respondents to answer questions would be short las the research was mainly carried out in the GP waiting room). In the next paragraph the HBM is discussed in some detail.

\section{THE HEALTH BELIEF MODEL}

According to Becker and Maiman (1975), the origins of the HBM are to be found in a well-established body of psychological and behavioural theory (cf. Mechanic, 1972); various models hypothesize that behaviour depends mainly upon two variables: (1) the value placed by an individual on a particular goal; and (2) the individual's estimate of the 
likelihood that a given action will achieve that goal. Adapting these variables to health related behaviour leads to the conclusion that the following two derived variables may be considered as central concern in explaining health actions: (1) the desire to avoid illness (or if ill, to get well); (2) the belief that a specific health action will restore health, prevent for ameliorate) illness (i.e. the individual's estimate of the threat of illness, and of the likelihood of being able to reduce that threat through personal action).

Furthermore, the developers of the HBM felt that some stimulus was necessary to trigger the decision-making process. What are called 'cues to action' might be internal (i.e. symptoms) or external (i.e. mass media communications or interpersonal interactions). Here, the HBM will be explained further by taking GP consultation behaviour as an example.

According to the HBM (see Figure 1), the decision to consult the GP can be explained by three factors: the extent to which a person perceives a threat to his or her health, the degree to which a person believes that a GP consultation will be effective in reducing that threat, and cues to action which prompt a person to consult the GP.

The perception of a threat is itself influenced by general health values, specific beliefs about the seriousness of the complaint and the vulnerability to a serious disease. Apart from the perceived efficacy of GP consultation, the other benefits the person sees in consulting the GP and the disadvantages, costs or effort (barriers) of a GP consultation are taken into account. The more benefits, and the fewer barriers the person perceives, the greater the possibility that he or she consults the GP. The actual cue that triggers the GP consultation may be personal advice to consult the GP or reception of information about the complaint from medical programmes on radio or television.

\section{Individual perceptions Modifying factors Likelihood of action}

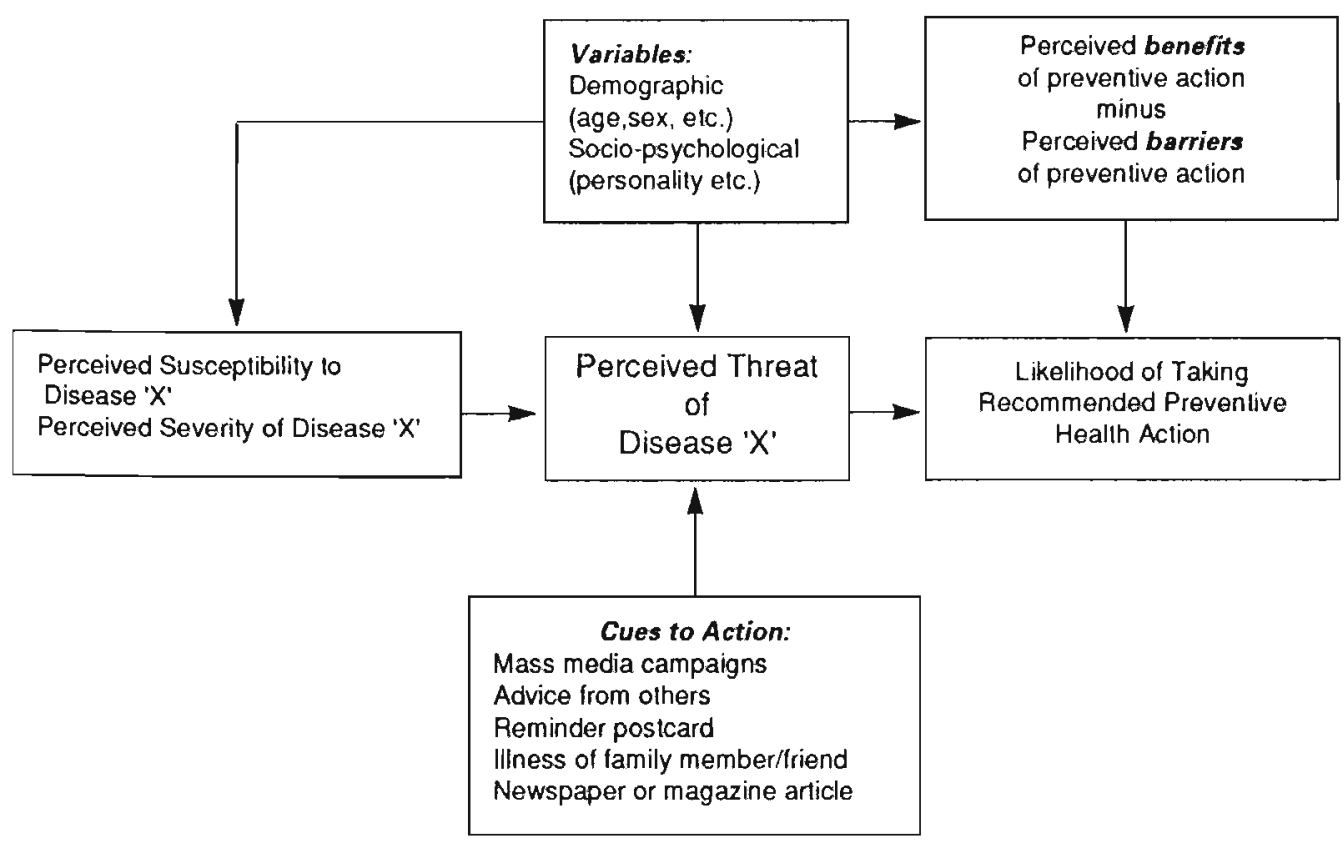

Figure 1. The Health Belief Model (Becker \& Maiman, 1975) 
An advantage of using the HBM is that it has been used to explain many health related actions and also been tested in numerous studies (cf. Janz \& Becker, 1984; Harrison et al., 1992). Most investigations already provide empirical evidence supporting HBM elements as predictors of individuals' health related behaviours.

Careful consideration of the factors mentioned in the HBM in relation to GP consultation led to several small changes and specifications of the model (see Figure 2). Firstly, apart from the perceived effectiveness of professional medical care, the perceptions patients have of their own possibilities to cope with the complaints may be expected to influence the decision to consult the GP (Hochbaum, 1983; Grimsmo \& Siem, 1984; Strecher et al., 1986; Jones, 1987). Even if patients accord a high rating to the GP's ability to help, they may decide not to use professional care if they accord a similar high rating to their own effectiveness in coping with the complaints

Background characteristics

Consultation variables:
Client of same GP
Consultations per year
Last consultation
Socio-psychological variables:
Healih status
Usual action when ill
Demographic variables:
Sex
Age
Marital status
Socio-Economic Status variables:
Education
Occupation
Insurance
Income

\section{Perceptions}

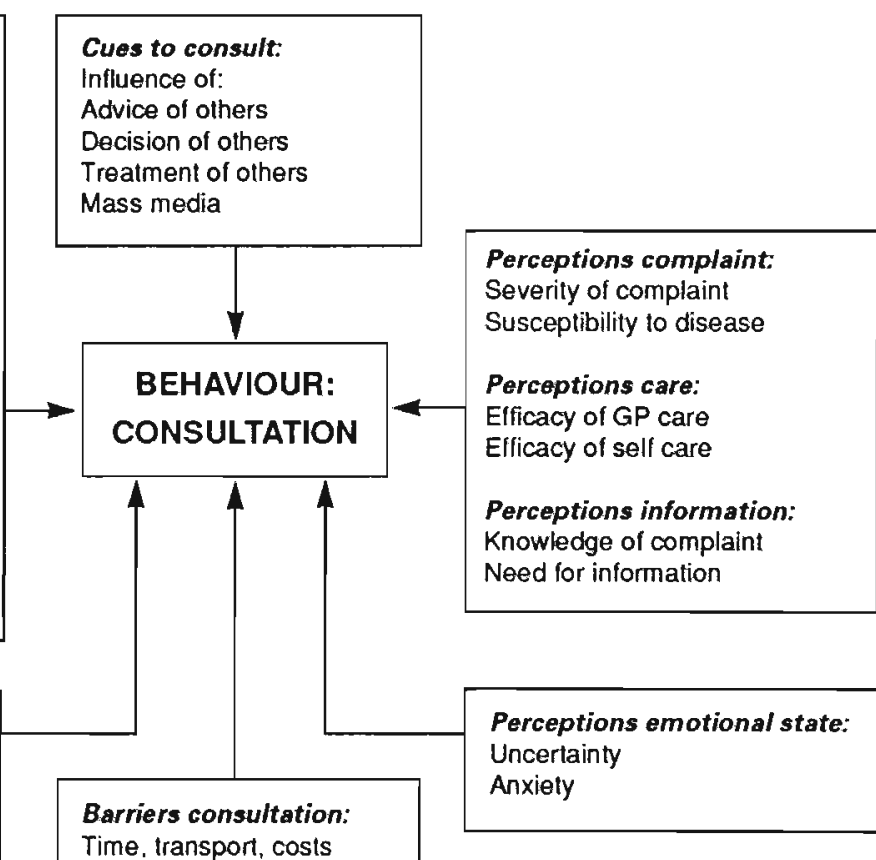

Figure 2. GP consultation model

Secondly, it is plausible that one reason why people consult the GP is that they need more information, rather than treatment. Need for information especially may play an important role in the decision to consult the GP, because the GP is often perceived by patients as an all-round doctor who can therefore provide information on all types of conditions.

Thirdly, one might argue that some variables should be measured more specifically or directly, because it is often suggested that the more specifically a certain concept is measured, the more predictive it is of behaviour (Ajzen \& Fishbein, 1980). Susceptibility to 
disease, for example, may be measured by asking patients about the perceived chance that the complaints for which the individual is consulting the GP now is indicative of a severe illness and not about their general susceptibility to disease. Furthermore, patients might be asked directly if they are concerned about the complaint, instead of measuring perceived threat indirectly by perceived susceptibility and severity of the complaint.

Finally, the HBM does not try to fill in the social aspects of the factor 'cues to action'. Another behavioural model developed by Ajzen and Fishbein (1980), however, stresses social influences as an independent and important factor. Their research findings have often shown that these social factors may provide a useful specification of the more general factor 'cues to action'. This 'elaborated HBM' functioned as the basis of the research presented in the next section.

\section{METHODS}

To answer the research questions a study was conducted in the waiting rooms of eight (urban) general practices. One thousand patients completed a questionnaire before they consulted the GP (see Annex 2). The questionnaire addressed possible determinants of consulting the GP (based on the elaborated HBM), the worry experienced by patients, and background characteristics. The patients included in the study also received a second questionnaire after consultation (see Annex 3 ). This questionnaire tried to measure changes in health beliefs and worry related to the complaint presented during the consultation. This questionnaire also asked whether patients experienced another complaint at the same time, for which they had decided not to consult the GP. For this complaint, if present, they had to answer the same questions (on determinants) as for the complaint for which they had decided to consult the GP for (first questionnaire). Both questionnaires were first judged by several experts and after that pretested on 30 patients of the target population. This pretesting resulted in minor changes of and additions to the questionnaires.

The presentation of the results of the rather extensive set of data gathered is clustered around three aspects. Firstly, in chapter 2, a study into the determinants of GP consultation is described. The factors investigated are derived from the HBM, elaborated with the inclusion of the factors just mentioned in the critical examination of the model. To determine what the main determinants of GP consultation are, we compared the answers which one group of patients gave to the questions in the first questionnaire (that referred to the complaint for which they consulted the GP) with the answers another group of patients gave to the questions in the second questionnaire (that referred to the complaint for which they did not consult the GP).

Secondly, attention is paid to the worry patients experience, the backgrounds to this worry and how it is influenced by the consultation (chapter 3). Also the relation between reduction in worry and satisfaction with the consultation was examined; we hypothesized that the more satisfied patients were with the discussion of worry in the consultation, the greater the reduction would be in their degree of worry.

The third focus in the presentation of the results is on the effects the consultation has on determinants other than worry, and on how these effects are related to satisfaction with aspects of the consultation (chapter 4 . For example, it is examined whether need for information and perceived severity of the complaints is reduced, and how these factors are affected by the patient's level of satisfaction.

Apart from the observational study described above, we carried out two small studies, reported in chapter 5, to investigate whether the relation of the determinants 
found in the observational study have a causal relation to the decision to consult the GP. The causality of the relation is particularly important if the intention is to use the relations found to develop an intervention aimed at changing people's consultation behaviour: here information is needed on whether changes in one variable (for example health beliefs) cause changes in other variables (in this case: deciding to consult the GP).

In order to gain insight in the causality of the relations, we chose a rather unusual method in health sciences: 'scenario studies'. In the scenario studies, stories describing a person reading an article or watching a TV programme about a certain disease were presented to 160 subjects (Health Sciences students). In every story four independent variables were systematically manipulated on a high or low level. For example, a disease was described in one story as very serious (high severity) and in another story as not serious (low severity).

In a brief introduction the subjects, who had to read the stories, were asked to imagine that they would find themselves in this situation and to indicate how worried they would feel and how strong their inclination would be to consult their GP. In the first scenario study a selection was made of two perceptions of a complaint (severity and susceptibility) and two perceptions of care (effectiveness of GP care and self care) as independent variables. Subjects were asked to indicate how worried they would feel and how strong their inclination would be to see their GP.

Scenario study 2 had some variables in common with study 1 : here also susceptibility and severity were manipulated. In addition to these factors, we tested whether coincidental information (about a friend who happened to have the same symptoms, and in whom the medical treatment did or did not succeed) influenced worry and intention to consult the GP. Further 'objective' statistical information on the probability of success or failure of the medical treatment was varied between conditions.

\section{CONCLUSIONS}

This overview only addresses the main conclusions of the research conducted; for a detailed presentation of methods, results and conclusions the reader is referred to the chapters 2 to 5 . The conclusions are presented in three parts: corresponding to the implications the studies have for theory, practice, and methods, respectively.

\section{Theoretical conclusions}

The first overall conclusion is that the HBM seems to be a useful instrument to explain the decision of patients to consult the GP. The HBM elements, like perceived severity of the complaint, and effectiveness of GP care, explained an important portion of variance of the decision to consult the GP. Remarkably, perceived susceptibility to a serious disease could not explain the decision to consult the GP in the observational study. This may be related to the fairly innocent complaints the GP generally has to cope with. In the scenario studies an unexpected finding was that efficacy of GP care seemed to have no effect on the decision to consult the GP. This finding, however, may be an artifact of the experimental situation: the unknown disease may have caused a greater need for information.

We may also conclude that the variables susceptibility and severity, which are considered to be the main elements of worry or perceived threat in the HBM, indeed seem to play a prominent role in the general worry patients consulting the GP experience. Moreover in both scenario studies the perceived susceptibility and severity mainly determined the subjects' worry. 
We were especially interested in whether perceptions of self care and information are useful additions to the HBM when this model is used to explain the decision to consult the GP. The results of both the observational and the scenario studies show that perceptions concerning self care do influence the decision to consult the GP. When patients feel that the complaint can be treated without the help of the GP, they will be less inclined to consult the GP (cf. Grimsmo \& Siem, 1984). The need for information also seemed to be an important reason for patients to consult the GP (cf. Like \& Zyzanski, 1986). Thus, the findings suggest that perceived possibilities for self care and need for information should be added to a model explaining GP consultation.

Previous research had not dealt specifically with the effect of advice from others as an important cue to consult the GP. The fact that knowing someone with the same complaint did not yield an effect on the decision to consult the GP in the observational study may have been the result of the small number of respondents reporting such knowledge. The influence of others, a neglected element of the HBM, may, however, be worth further investigation.

\section{Practical conclusions}

The results give valuable information for the daily practice of the GP. The practical conclusions can be focused on the important reasons for consulting the GP, how to cope patients' worry or more specifically causes of patients' worry, and finally how GP consultation can be improved.

First, it became clear that, apart from the perceived severity of the complaint, information plays an important part in explaining the decision whether or not to consult the GP. Patients who consult the GP often seem to want more information about the complaint and the suitable treatment for this complaint. This study indicates or indeed confirms the importance of the informative function of the GP care. Thus, GPs should realize that the reason why patients consult them sometimes may be that they want more information, rather than medical treatment. This is especially important because a perceived lack of information may lead to worry in patients. Additionally, more information about the potential effectiveness of medical care for a certain complaint could offer patients the possibility to choose the most appropriate care.

Furthermore, our findings indicate that complaint variables, like frequency, duration and awareness of causes, do not seem to be very important for understanding why people consult the GP. The way patients perceive their complaint (with respect to severity, effectiveness of self care and GP care, cf. Van de Lisdonk, 1985) influences their decision to consult the GP. Of course, the way people perceive their complaint may differ considerably from the way the complaint should be viewed objectively. But no restrictions were made as far as patients' complaints were concerned: chronic, intermittent and new complaints were all included. Patients were asked to mention the single most important or main complaint in the questionnaire.

This study focused on complaint characteristics, such as frequency or duration of the complaint, as determinants of consulting the GP. Future research could focus on specific complaints, such as low back pain or headache as determinants of consulting the GP.

We were interested in the question whether consulting the GP can reduce patient worry. An answer could give some information for the GP about how to cope with causes of patients' worry. The analysis of the change in the degree of worry after the consultation showed that consulting the GP had a positive effect on patients' worry, especially on worry about the complaint. Consultation seems to have a reassuring effect on patients, especially for those patients who are satisfied with the consultation. For the GP 
it is important to know that worry is related to patient characteristics (like sex or health status), but more by the way patients perceive their complaint. Apart from the patients' perceptions of the severity of the complaint and the susceptibility to a serious disease, the need for more information is an important dimension in patient's worry. We may conclude that if a GP discusses the complaint and the concomitant worry to the patient's satisfaction, this may lead to a decrease in worry. However, some reserve is warranted with respect to this conclusion. Since patients consulting the GP were not compared to patients not consulting the GP, the reduction in worry might possibly be attributed to other factors than the consultation.

Furthermore, not surprisingly, several background characteristics which all seem to have a relation with the patient's health status (like duration of the complaint and number of consultations per year) seem to determine patient's worry. A salient finding is that perceptions of the possibilities of care (GP care or self care) do not seem to influence the extent to which patients feel worried. We had expected rather that patients who feel that their complaint can be treated adequately would feel less worried than patients who feel that their complaint cannot adequately be treated.

In general, there seems to be a positive effect of consulting the GP and patients are satisfied about the opportunity and about the information given by the GP during the consultation. Careful consideration needs to be given, however, to the fact that the effect of consulting the GP can be negative in some respect for dissatisfied patients. Recognizing that consultation is at least a two-way process, interventions in which the GP is trained to ask about patients' health beliefs and the patient is prepared to express his or her expectations during consultation may be further developed and evaluated in future research. In this context, it should be recognized that an important, and sometimes the most important, reason for patients to consult a GP is that they want more information; of course GPs should provide this information when possible.

Furthermore, to reduce unnecessary worry in patients, it should be stressed that it is useful to elicit the patients' perceptions of the complaint, and to provide reassuring and detailed information with respect to these variables where possible. On the patients' side, an intervention could perhaps aim at having patients making notes of what they want to know in advance. Improving the provision of information by both the GP and the patient may reduce the concomitant problems of dissatisfaction with health care and worry (Roter, 1977; Fletcher, 1979; Hannav, 1979; Stewart et al., 1979; Krantz et al., 1980; Pendleton \& Hasler, 1983).

\section{Methodological conclusions}

The research conducted gives us the opportunity to compare the results obtained by two, quite different, research methods. An observational study, conducted in 'real life', and an experimental 'paper and pencil study'. The results show that in general the scenario studies yield the same findings as the observational study. Comparing results in the real world and in an artificial situation, however, also showed some discrepancies. Thus, al-though scenario and observational studies may be complementary methods, scenario studies should not substitute for observational studies. Because most findings do match, scenario studies may be useful in exploring relatively unknown fields. In conclusion, inasmuch as these scenario studies may contribute to GPs not being consulted unnecessarily by patients, perhaps they also may contribute to patients not being consulted unnecessarily by researchers (although in both cases unnecessary delay can give rise to problems). 


\section{LIMITATIONS}

Finally we attend to the main shortcomings of the studies reported. The observational study has several aspects that may limit generalizability of the results. First, the population only comprises of patients consulting the GP. People who rarely consult the GP could present many differences. It may be that they have a different state of mind, for instance a lack of confidence in medical care. Their emotional state could also differ considerably: perhaps they dare not to consult the GP because they are too anxious.

Second, considering the design used, one should not draw conclusions too easily about the effects of the consultation on health beliefs and worry: we did not compare patients who did consult the GP with patients who did not consult the GP. Because of the lack of such a control group, changes in health beliefs and worry may be due to other factors than the consultation itself, for example the effect of time.

Third, the study was also limited by depending only on patients' self reports. We had no complementary information from the GP, which could contribute to ensuring a correct interpretation of patients' health beliefs or consultation behaviour.

Furthermore, because of the explorative and correlational character of this study, we cannot draw definitive conclusions about the direction of causality of all relations found. This last shortcoming was partly solved by both scenario studies: in these studies some of the determinants were tested for their causal effect on the decision to consult the GP. However, in solving one shortcoming, another aroze: the scenario studies had a somewhat artificial character. A comparison of the observational and the scenario studies, however, reduced our worry about this artificial nature. Both studies in general yielded the same results; and we feel rather confident that with these complementary methods we have gained insight into the reasons why patients consult their GP and into their complaint related worry.

\section{FINAL REMARKS}

The research has enabled theoretical, practical and methodological conclusions to be drawn. Firstly, the HBM is a useful model to explain GP consultation behaviour, though the elaboration of the HBM with two factors (efficacy of self care and need for information) might be considered. Secondly, though a GP consultation in general seems to have a positive effect on health beliefs (for example worry) and leads to less need for knowledge, patients still feel they do not have enough information when they leave the GP. Both the patient and the GP might profit from more structured exchange of information. Thirdly, with respect to the methodology, we conclude that observational studies and scenario studies may sometimes be used as complementary methods; observational studies give information about relations in real life settings, scenario studies may give causal information about the same relations in a somewhat artificial situation. Furthermore, scenario studies may be recommended to explore relatively new research areas. 


\section{REFERENCES}

Ajzen, 1., \& Fishbein, M. (1980). Understanding attitudes and predicting social behavior. Englewood Cliffs: Prentice Hall.

Becker, M.H. (Ed.). (1974). The Health Belief Model and personal health behavior [Special issue]. Health Education Monographs, 2, 326-473.

Becker, M.H., \& Maiman, L.A. (1975). Sociobehavioral determinants of compliance with health and medical care recommendations. Medical Care, 13, 10-24.

Berkanovic, E., Telesky, C., \& Reeder, S. (1981). Structural and social psychological factors in the decision to seek medical care for symptoms. Medical Care, 19, 693-709.

Calnan, M. (1984). The Health Belief Model and participation in programmes for the early detec-tion of breast cancer: A comparative analysis. Social Science and Medicine, 19, 823-830.

Cassee, E. (1973). Naar de dokter. Enkele achtergronden van ziektegedrag en gezondheidszorg. Dissertatie. Meppel: Boom.

Cummings, K.M., Becker, M.H., \& Maile, M.C. (1980). Bringing the models together: An empirical approach to combining variables used to explain health actions. Journal of Behavioral Medicine, 3, 123-145.

Fletcher, C. (1979). Towards better practice and teaching of communication between doctors and patients. In G. McLachlan G (Ed.), Essays on Current Research. Twelfth Series, Nuffield Provincial Hospitals Trust: Mixed Communications Problems and Progress in Medical Care (pp. 3-41). Oxford: University Press.

Green, L.W., Kreuter, M.W., Deeds, S.G., \& Partridge, K.B. (1980). Health Education Planning: A Diagnostic Approach. Palo Alo, CA: Mayfield.

Grimsmo, A., \& Siem, H. (1984). Factors affecting primary health care utilization. Family Practice, 1, 155-161.

Grinten, R., van der. (1988). Inbreng van patienten. Een onderzoek van spreekuurkontakten. Dissertatie. Nijmegen: Katholieke Universiteit Nijmegen.

Hannay, D.R. (1979). The symptom iceberg. London: Routledge \& Kegan Paul.

Harrison, J.A., Mullen, P.D., \& Green, L.W. (1992). A meta-analysis of studies of the Health Belief Model. Health Education Research, Theory \& Practice, 7, 107-116.

Hochbaum, G.M. (1983, November). The Health Belief Model revisited. Paper presented at the Annual Meetings of the American Public Health Association, Dallas, Texas.

Hofmans-Okkes, I. (1991). Op het spreekuur. Oordelen van patienten over huisartsconsulten. Dissertatie. Lelystad: Universiteit van Amsterdam.

Janz, N.K., \& Becker, M.H. (1984). The Health Belief Model: A decade later. Health Education Quarterly, 11, 1-47.

Jessen, J.L. (1974). Medische consumptie: onderzoek naar medische consumptie van de Nederlanders anno 1970. Dissertatie. Groningen: Rijksuniversiteit Groningen.

Jones, R. (1987). Self-care and primary care of dyspepsia: A review. Family Practice, 4, 68-77.

Jongh, T., de (1987). Ongerustheid, een eerstelijnsziekte. Medisch Contact, 42, 828-830.

Krantz, D.S., Baum, A., \& Wideman, M., van. (1980). Assessment of preferences for self-treatment and information in health care. Journal of Personality and Social Psychology, 5 , 977-990.

Leavitt, F. (1979). The Health Belief Model and utilization of ambulatory care services. Social Science and Medicine, 13A, 105-112.

Like, R., \& Zyzanski, S.J. (1986). Patient requests in family practice: A focal point for clinical negotiations. Family Practice, 3, 216-228

Lisdonk, E., van de. (1985). Ervaren en aangeboden morbiditeit in de huisartsenpraktijk. Dissertatie. Nijmegen: Katholieke Universiteit Nijmegen. 
Lydeard, S., \& Jones, R. (1989). Factors affecting the decision to consult with dyspepsia: Comparison of consulters and non-consulters. Journal of the Royal College of General Practitioners, 39, 495-498.

McKinlay, J.B. (1972). Some approaches and problems in the study of the use of services - An overview. Journal of Health and Social Behavior, 13, 115-152.

Mechanic, D. (1972). Social psychological factors affecting the presentation of bodily complaints. The New England Journal of Medicine, 25, 1132-1139

Mullen, P.D., Hersey, J.C., \& Iverson, D.C. (1987). Health behavior models compared. Social Science and Medicine, 24, 973-981.

Neven, J. (1980). Uitstelduur en praktijkvoering. Een onderzoek in een aantal huisartsenpraktijken. Dissertatie. Maastricht: Rijksuniversiteit Limburg.

Oliver, R.L., \& Berger, P.K. (1979). A path analysis of preventive health care decision models. Journal of Consumer Research, 6, 113-122.

Pendleton. D., \& Hasler, J. (Eds.). (1983). Doctor-Patient Communication. New York: Academic Press.

Prentice-Dunn, S., \& Rogers, R.W. (1986). Protection Motivation Theory and preventive health: beyond the Health Belief Model. Health Education Research: Theory and Practice, 1. 153-161.

Rieff, T., \& Bremer, J. (1982). De rol van angst bij de medisch consumptie van astmapatiënten: De Denverse onderzoeken. De Psycholoog, 17, 721-727.

Robinson, E.J., \& Whitfield, M.J. (1987). Participation of patients during general practice consultations: Comparison between trainees and experienced doctors. Family Practice, 4 , 5-10.

Rogers, R.W. (1983). Cognitive and physiological processes in fear appeals and attitude change: a revised theory of protection motivation. In J. Cacioppo and R. Petty (Eds.), Social Psychology: A Sourcebook (pp. 153-176). New York: Guilford Press.

Rosenstock, I.M. (1974). The health belief model and preventive health behavior. Health Education Monographs, 2, 354-386.

Roter, D.L. (1977). Patient participation in the patient-provider interaction: The effects of patient question asking on the quality of interaction, satisfaction and compliance. Health Education Monographs, 5, 281-315.

Stewart, M.A., McWhinney, I.R.; \& Buck, C.W. (1979). The doctor / patient relationship and its effect upon outcome. Journal of the Royal College of General Practitioners, 29, 77-81.

Strecher, V.J., McEvoy De Vellis, B., Becker, M.H., \& Rosenstock, I.M. (1986). The role of selfefficacy in achieving health behavior change. Health Education Quarterly, 13, 73-91.

Taylor, S.E. (1986). Health Psychology. New York: Random House.

Zee, J., van der. (1982). De vraag naar diensten van de huisarts. Dissertatie. Maastricht: Rijksuniversiteit Limburg. 


\section{CHAPTER 2}

\section{WHY DO PATIENTS CONSULT \\ THE GENERAL PRACTITIONER? \\ Determinants of their decision.}

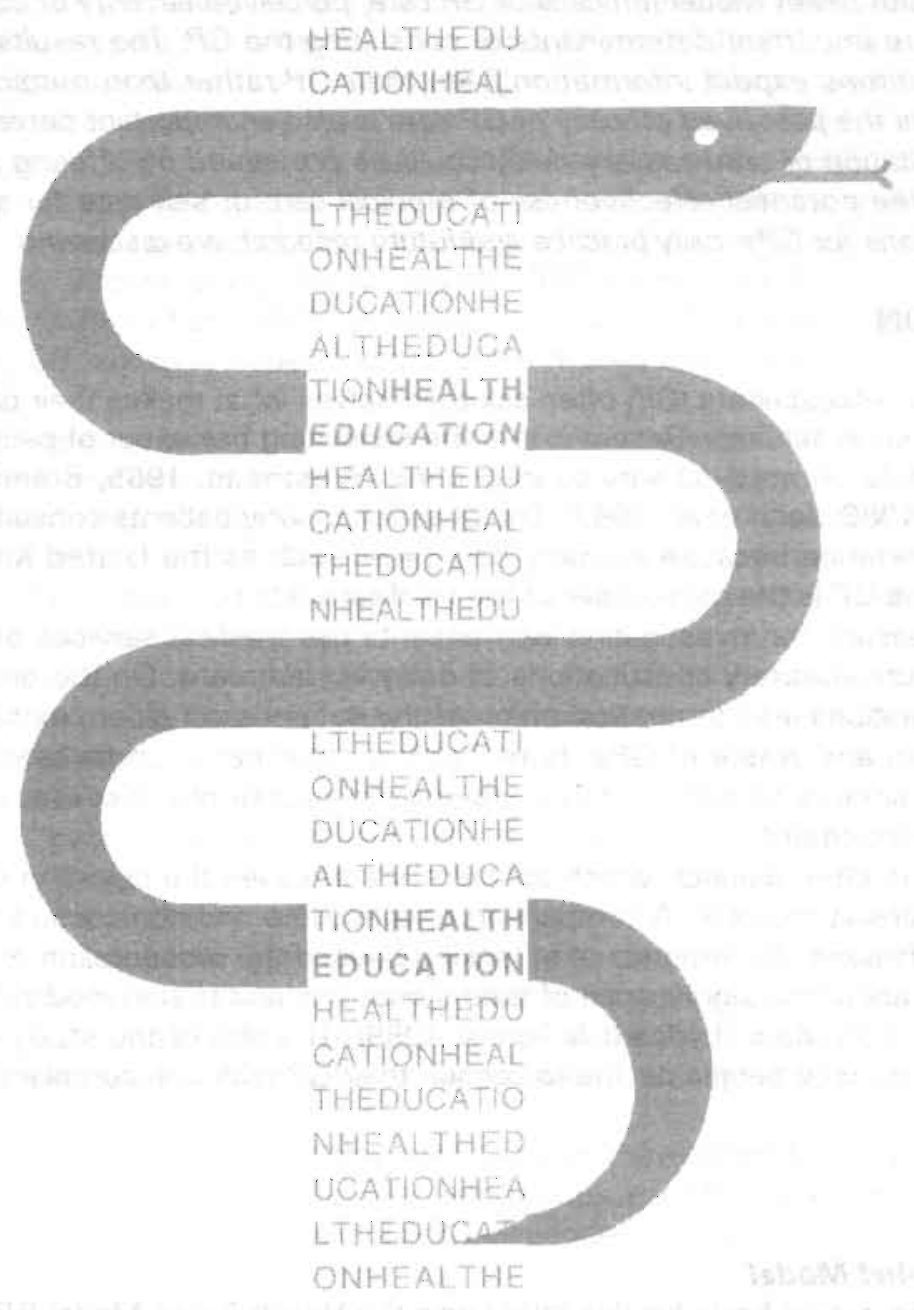

Published as: Kar, A.G.A., van de, Knottnerus, J.A., Meertens, R.M., Dubois, V. \& Kok, G.J. (1992). Why do patients consult the general practitioner? Determinants of their decision. British Journal of General Practice, 42, 313-316. 


\section{Abstract}

In order to obtain more information about the reasons why patients consult their general practitioner (GP), 1000 patients completed a questionnaire in the waiting rooms of eight general practices. After the consultation the patients received a second questionnaire. The aim of the study was to determine why people decide to consult their GP about one complaint but not about a second complaint. Both questionnaires were based on the Health Belief Model, augmented by two other factors: the perceptions patients have of their own abilities to cope with their condition (efficacy of self care), and their need for information. The results showed that the two additional factors as well as most of the factors of the Health Belief Model lefficacy of GP care, perceived severity of complaint, cues to consult) were important determinants of consulting the GP. The results suggest that patients sometimes expect information from their $G P$ rather than medical treatment. Furthermore, as the perceived efficacy of GP care is also an important determinant, unnecessary consultation or unnecessary delay could be prevented by offering patients information about the potential effectiveness of medical care or self care for specific conditions. Implications for GPs' daily practice and future research are discussed.

\section{INTRODUCTION}

General practitioners (GP) often ask themselves what makes their patients decide to use their medical services. Research into the consulting behaviour of patients has been focused primarily on medical service in general (Westhead, 1985; Branch \& Nemeth, 1985; Schrire, 1986; John et al., 1987). The question of why patients consult their GP is of particular importance because in many countries, such as the United Kingdom or the Netherlands, the GP is the gatekeeper of the medical system.

The reasons for investigating why patients use medical services often seems to be to prevent unnecessary consultations or delay in treatment. On the one hand, unnecessary consultations lead to medicalization of the patient's condition, extra costs for the medical system and waste of GPs' time. On the other hand, unnecessary delay for a patient with a serious complaint, could prolong the course of a disease, or necessitate more complex treatment.

There is little research which specifically addresses the question of why people do or do not consult their GP. A comparison of consulters and non-consulters by Lydeard en Jones emphasized the importance of looking beyond the presentation of symptoms to patients' fears about the significance of their symptoms and to non-medical determinants of consultation behaviour (Lydeard \& Jones, 1989). The aim of the study reported here was to determine why people decide to consult their GP with one complaint, but not with another

\section{METHODS}

\section{The Health Belief Model}

The theoretical basis for this study was the Health Belief Model (HBM), originally formulated to explain (preventive) health behaviour, such as breast self examination or attending a screening programme (Becker \& Maiman, 1975). The model assumes that subjective health considerations determine whether people perform a health related action, such as consulting their GP. For example, the HBM considers the perceived, rather than the real, severity of the complaint to be the propelling force behind the action. 
According to the HBM, the decision to consult the GP can be explained by three factors: the extent to which a person perceives a threat to his or her health, the degree to which a person believes that a consultation with the GP will be effective in reducing that threat, and 'cues to action' which prompt a person to consult the GP. Cues to consult the GP might be internal, that is symptoms, or external, that is mass media communications or interpersonal interactions.

The perception of a threat is itself influenced by general health values, specific beliefs about the seriousness of the complaint and the vulnerability to a serious disease. Apart from the perceived efficacy of consultation with the GP, both the benefits of and the barriers to such a consultation are taken into account. The more benefits, and the fewer barriers people perceive, the greater the possibility that they will consult the GP. The actual cue that triggers the consultation may be personal advice to consult the GP or information about the complaint from medical programmes on radio or television.

Although other approaches have been used (Tanner et al., 1983; Janz \& Becker. 1984; Markides et al., 1985; Hibbard \& Pope, 1986; Harrison et al.. 1992) the HBM is the most widely applied approach to the explanation of medically based preventive actions and underlies several studies of the utilization of medical services (Becker, 1974; Rosenstock, 1974; Becker et al., 1977; Leavitt, 1979; Cummings et al., 1980; Kirscht. 1983; Cox, 1986; Mullen et al., 1987). However, in order to investigate the determinants of consulting the GP, we have added factors to the model, and made others more specific.

First, it was considered that, apart from the perceived effectiveness of professional medical care, the perceptions patients have of their own possibilities to cope with the complaint would influence the decision to consult the GP (Hochbaum, 1983; Grimsmo \& Siem, 1984; Strecher et al., 1986). Even if patients accord a high rating to the GP's ability to help, they may decide not to use professional care if they accord a similar high rating to their own effectiveness in coping with the condition.

Secondly, it is plausible that people consult the GP because they need information rather than treatment. This need may play an important part in the decision to consult, as the GP is often perceived by patients as an all-round doctor who can therefore provide information on all types of conditions.

Thirdly, it was decided to measure some variables more specifically than usual, because it is often suggested that the more specifically a certain concept is measured, the more predictive it is of a specific behaviour (Ajzen \& Fishbein, 1980). Patients were therefore asked not about their general susceptibility to disease, but about the perceived chance that the presenting complaint was indicative of a severe illness. Furthermore, patients were asked directly if they were concerned about their health in general instead of measuring the perceived threat indirectly by perceived susceptibility to and severity of the complaint.

Finally, the social aspects of the cues to action have been taken into consideration. Although the HBM does not focus on social cues specifically, Ajzen and Fishbein (1980) stress social influences as an important independent factor.

\section{Sample}

In the period mid-November to mid-December 1988 a questionnaire was given to patients in the waiting rooms of eight urban general practices in the province of Limburg, the Netherlands. The only inclusion criterion used was that patients had come to consult the GP of their own free will. Therefore, patients who came for a medical check up or at the invitation of the GP for a follow-up consultation were excluded from the study. 
Children who could explain why they were waiting for the GP and could answer the questions were included. No restrictions were made as far as the complaints of the patients were concerned - patients with chronic, new and intermittent complaints were included. Questionnaires were handed out until a total of 1000 had been completed.

\section{Questionnaires}

Patients were asked to state the single most important or main complaint in a first questionnaire (see Annex 2 and Figure 1). After the consultation the respondents received a second questionnaire, which could be filled in at home and posted back to the department of Health Education (see Annex 3).

\section{Questions}

\section{Characteristics of complaint}

Have you had this complaint before ${ }^{a}$

For how long has this complaint been bothering you ? $^{b}$

Have you tried something to treat this complaint ${ }^{c}$

Are you aware of the cause of this complaint? $d$

\section{Health bollofs}

Do you think your complaint is serious ${ }^{\ominus}$

Do you think your complaint has to do with a serious disease? ${ }^{f}$

Do you think the GP can treat your complaint f $^{t}$

Do you think that you could have treated your complaint yourself ?

Do you think you know enough about your complaint ${ }^{9}$

Do you need more information about your complaint?

\section{Cues to consult}

Did people advise you to consult the GP?h

Did this advice influence your decision to consult the GP?

Do you know someone with the same complaint ? $^{\text {h }}$

Did the decision of this person to consult their GP influence your decision?

Did the result of the treatment of this person influence your decision?

Did you receive information from the media about your complaint ?h $^{\text {h }}$

Did this information influence your decision? ${ }^{i}$

\section{Emotional state}

Do you feel worried about your health at this moment?

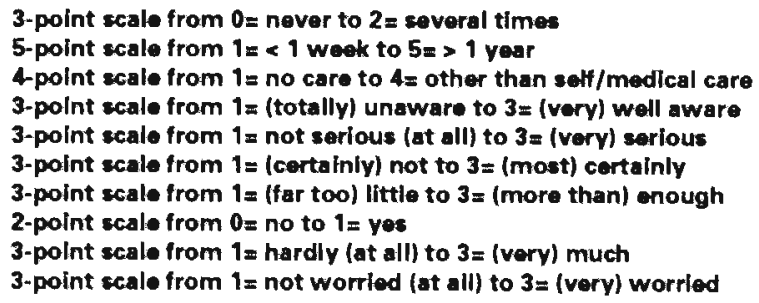

Figure 1. Patient interview questions 
Both questionnaires had been pretested and included items on the possible reasons for consulting the GP and presenting the complaint. In the first questionnaire the patients were asked about aspects of the main complaint, their health beliefs to consulting, cues to consulting the GP and their emotional state. After the consultation the second questionnaire asked the patients to mention a second complaint which they had, but about which they did not or would not consult the GP. For these complaints the questions about determinants asked in the first questionnaire were repeated.

In order to reduce the time and effort needed to answer the first questionnaire in the waiting room, all questions that could be asked after the consultation were put in the second questionnaire. Therefore background characteristics were covered in the second questionnaire using closed questions. These included: consultation variables - length of time with same GP, number of consultations per year and lenght of time since last consultation; psycho-social variables - health status ("Do you feel healthy compared with other people of the same age?") and usual action when ill; demographic variables - sex, age, marital status, education, occupation, health insurance and income. Also barriers to consulting were asked in the second questionnaire. These barriers concerned time, transport and costs. Finally, open questions gave the respondents the chance to mention other determinants, cues to consulting the GP or reasons for being worried.

\section{Statistical analysis}

In order to explain the decision to consult the GP, the scores for health beliefs, cues to consult and emotional state for the main complaint were compared with those for the second complaint. First, the background characteristics of those who did not mention a second were compared. Further statistical analysis was focused on those who completed both questionnaires and who reported a complaint which they did not present. Secondly, multiple logistic regression analysis was used to examine the contribution of selected determinants to the prediction of the decision to consult the GP (Afifi \& Clark, 1984).

The selected determinants were variables which were assessed using a three point scale. In the logistic model the 'do not know' and 'not applicable' conditions were omitted and the extremes compared. Fitting the logistic regression model was carried out in three stages: including only the determinants from the HBM; adding the perception of efficacy of self care and need for information and knowledge about the complaint to the $\mathrm{HBM}$; and adding characteristics of the complaint: frequency, duration, and awareness of cause.

\section{RESULTS}

Of the 1000 patients completing the first questionnaire $791(79.1 \%$ ) also returned the second questionnaire. Of these 791 patients 450 mentioned a second complaint.

Pqssible sample bias resulting from patients who did not return the second questionnaire was evaluated by two-sided univariate comparisons between selected characteristics of the 791 respondents and 209 non-respondents. This analysis revealed no significant differences between respondents and non-respondents in terms of the characteristics of the complaint presented to the GP, health beliefs, cues to consult and emotional state. It can therefore be concluded that selective non-response is unlikely to be a source of bias in generalizing the results of further analyses.

The background characteristics of the 341 patients who mentioned only the complaint presented to the GP and the 450 patients selected for further analysis, who also mentioned a second complaint which they did not present to the GP were compared. 
Significant differences were found for the following variables: usual action when ill, sex, age, marital status and education. Patients who mentioned only one complaint rarely waited to see if the complaint improved spontaneously but preferred to consult the GP. These respondents, were also more likely to be male, older, married and less highly educated

\section{Background characteristics of analysis sample}

Most of the 450 respondents who mentioned a second complaint had had the same GP for a considerable time $(64.4 \%)$, and had consulted the GP between one and five times during the last year $(69.5 \%)$. their last consultation being less than three months previously $(71.8 \%)$. Of the respondents $41.8 \%$ stated that they felt healthy compared with others of the same age and $75.6 \%$ that they normally treated their complaints without consulting a GP. The majority of the patients were female $(64 \%)$, less than 45 years of age $(72.4 \%)$ and married $(57.6 \%)$. Of the respondents $49.3 \%$ had completed secondary education, $44.7 \%$ had a paid job and $39.9 \%$ a net income of $1500-2500$ guilders per month. Most of the 450 patients were insured with a public health insurance fund $(71.3 \%)$.

\section{Decision to consult}

Multiple logistic regression analysis was used to provide information about the contribution of selected determinants to the prediction of the decision to consult the GP about a complaint (see Table 1). Determinants with odds ratios less than 1.00 decrease the likelihood of consulting the GP, whereas determinants with odds ratios greater than 1.00 increase the likelihood.

Considering model 1 - the basic elements of the HBM - the perceived influence of advice to consult the GP (OR $=3.12, P=0.001)$, efficacy of GP care $(\mathrm{OR}=3.17, P=$ $0.001)$ and severity of the complaint (OR $=3.62, P=0.001)$ were significantly and positively associated with the decision to consult the GP. suggesting a determining effect. Information received from the media (OR $=1.18, P=0.001$ ) also seemed to increase the likelihood of the patient consulting the GP. The overall model based on the elements of the HBM showed a high predictive value for consulting the GP (goodness of fit, $P=$ $0.989)$.

Efficacy of self care, knowledge about the complaint and need for information were added in model 2. Perceived efficacy of self care (OR $=0.18, P=0.001$ ) decreased the likelihood of consulting the GP while perceived need for information $(O R=2.89, P=$ $0.001)$ was positively associated with presenting a complaint.

Finally, three characteristics of the complaint - frequency, duration, and awareness of cause - were added to model 2. These variables did not change the results obtained from model 2. Advice from others to consult the GP, perceptions of the efficacy of GP care, self care, and need for information remained the important determinants of consulting the GP. 
Table 1. Significant factors from the multiple logistic regression model of the decision to consult the GP for the sample of $\mathbf{4 5 0}$ patients.

\begin{tabular}{|c|c|c|c|c|}
\hline & MODEL $1^{\mathbf{a}}$ & & MODEL $2^{b}$ & \\
\hline Variable & $\begin{array}{l}\text { Logistic } \\
\text { regression } \\
\text { coefficient } \\
\text { (SE) }\end{array}$ & $\begin{array}{l}\text { Odds } \\
\text { Ratio }\end{array}$ & $\begin{array}{l}\text { Logistic } \\
\text { regression } \\
\text { coefficient } \\
\text { (SE) }\end{array}$ & $\begin{array}{l}\text { Odds } \\
\text { Ratioc }\end{array}$ \\
\hline Intercept & $\begin{array}{c}0.005 \\
10.095)\end{array}$ & - & $\begin{array}{c}0.005 \\
(0.095)\end{array}$ & - \\
\hline \multicolumn{5}{|c|}{ Cues to consult } \\
\hline $\begin{array}{l}\text { Influence } \\
\text { Advice }\end{array}$ & $\begin{array}{c}1.138 \\
(0.400)\end{array}$ & $3.12^{\cdots}$ & $\begin{array}{c}1.136 \\
10.522)\end{array}$ & $3.12^{* * *}$ \\
\hline $\begin{array}{l}\text { Influence } \\
\text { Mass media }\end{array}$ & $\begin{array}{c}0.166 \\
(0.648)\end{array}$ & $1.18^{* * *}$ & $\begin{array}{l}-0.029 \\
10.7641\end{array}$ & $\begin{array}{c}0.97^{*} \\
(1.03)\end{array}$ \\
\hline \multicolumn{5}{|c|}{ Health Beliefs } \\
\hline Severity & $\begin{array}{c}1.286 \\
(0.228)\end{array}$ & $3.62^{* *}$ & $\begin{array}{c}0.868 \\
10.2421\end{array}$ & $2.38^{* * *}$ \\
\hline $\begin{array}{l}\text { Efficacy of } \\
\text { GP care }\end{array}$ & $\begin{array}{c}1.153 \\
(0.169)\end{array}$ & $3.17^{\circ \cdots}$ & $\begin{array}{c}1.383 \\
(0.213)\end{array}$ & $3.99^{* * *}$ \\
\hline $\begin{array}{l}\text { Efficacy of } \\
\text { Self care }\end{array}$ & & - & $\begin{array}{l}-1.717 \\
(0.347)\end{array}$ & $\begin{array}{c}0.18^{\cdots \cdots} \\
(5.56)\end{array}$ \\
\hline $\begin{array}{l}\text { Need for } \\
\text { Information }\end{array}$ & - & - & $\begin{array}{c}1.062 \\
10.214)\end{array}$ & $2.89^{* \cdots}$ \\
\hline
\end{tabular}

Health Belief elements.

Health Belief Model with addition of efficacy of self care, knowledge about complaint and need for information.

The inverse of an odds ratio less than 1.00 is presented in parentheses to facilitate comparison of the size of the variable's effect with that of a variable with an odds ratio greater than 1.00 .

SE = standard arrors.

* $P<0.05 ; * * * \quad P<0.001$ testing the null hypothesis that all paramethers are zero. 


\section{DISCUSSION}

This study focused on patients, interviewed in GP waiting rooms, who stated after the consultation that they had a second complaint which they did not present to the GP.

The results of logistic regression analysis using components of the HBM give valuable information on important determinants of consulting the GP. Heeding the advice of others to consult the GP was an important determinant. When patients perceived GP care as very effective and/or the complaint as very serious, they were also more likely to decide to consult the GP. These results are similar to those of Berkanovic and colleagues (1981). The results of this study suggest that the influence of others, a neglected element of the HBM, is worth further investigation. A noteworthy finding of this study was that worry about health in general and belief that the presenting complaint was indicative of a serious illness were not important variables in the decision to consult the GP.

We were especially interested in whether perceptions of efficacy of self care and need for information would be useful additions to the HBM when the model is used to explain the decision to consult the GP (Berkanovic et al., 1981; Grimsmo \& Siem, 1984; Calnan, 1984; Like \& Zyzanski, 1986; Cockburn et al., 1987). The results show that when patients felt that the complaint could be treated without the help of the GP, they will be less inclined to consult (cf. Grimsmo \& Siem, 1984). The need for information seemed to be an important reason for patients to present a complaint to the GP (cf. Like \& Zyzanski, 1986). Thus, efficacy of self care and need for information should be added to the HBM. However, the findings indicate that characteristics of the complaint - frequency, duration and awareness of causes - do not explain an additional portion of variance.

The way people perceive their complaint may differ considerably from the way the complaint should be viewed objectively (Hannay, 1979). The manner in which complaints are interpreted by patients has received relatively little research attention although Jones and colleagues (1981) have studied the significance attached to a set of symptoms. Three factors of perceived significance emerged: the first factor was defined by the extent to which symptoms were perceived as threatening, disruptive and painful; the second consisted of the familiarity of symptoms and the perceived personal responsibility for their occurrence; the third reflected how embarrassing the symptoms were.

The study reported here has several aspects that may limit the generalizability of the results. The population comprised only patients consulting the GP. It may be that people who rarely consult the GP have different beliefs, for example, a lack of confidence in medical care. Their emotional state could also differ considerably: their anxiety might prevent them consulting the GP.

The study is also limited in its ability to determine the effects of barriers to consulting the GP on the decision to consult: patients who did not consult because of perceived barriers could not, by definition, be subjects in the research. For the same reason the study could not determine whether patients with certain background characteristics are more inclined to consult the GP than patients with a different background, In addition, the study population consisted only of those people who had a second complaint they did not present. Analysis revealed that patients with only one complaint differed mainly with respect to socio-demographic variables from the patients with two complaints.

The study was limited by depending on self reports from patients. No complementary information from the GP was obtained, which could contribute to ensuring a correct interpretation of patients' health beliefs or consultation behaviour. 
These results have several implications for future research and the daily practice of the GP. First, it became clear that information played an important part in explaining the decision whether or not to consult. GPs should realize that patients may consult to obtain more information, rather than medical treatment. More information about the potential effectiveness of different types of care could offer patients the possibility to choose the most appropriate care.

Secondly, this study focused on complaint characteristics, such as frequency or duration of the complaint, as determinants of consulting the GP. Future research could focus on specific complaints, such as low back pain or headache, as determinants of consulting the GP. Furthermore, interventions could be developed where patients are informed about the effectiveness of medical care or self care for specific conditions. Such interventions might prevent unnecessary consultation or treatment delay, resulting in lower costs, less likelihood of the course of the disease being prolonged or more complex treatment necessitated and less waste of GPs' time. 


\section{REFERENCES}

Afifi, A.A., \& Clark, J. (1984). Computer-aided multivariate analysis. Belmont, CA: Wadsworth. Ajzen, I., \& Fishbein, M. (1980). Understanding attitudes and predicting social behavior. Englewood Cliffs: Prentice Hall.

Becker, M.H. (Ed.). (1974). The Health Belief Model and personal health behavior [Special issue]. Health Education Monographs, 2, 326-473.

Becker, M.H., \& Maiman, L.A. (1975). Sociobehavioral determinants of compliance with health and medical care recommendations. Medical Care, 13, 10-24.

Becker, M.H., Haefner, D.P., Kasl, S.V., Kirscht, J.P., Maiman, L.A., \& Rosenstock, I.M. (1977). Selected psychosocial models and correlates of individual health-related behaviors. Medical Care, 15 (Supplement), 27-46.

Berkanovic, E., Telesky, C., \& Reeder, S. (1981). Structural and social psychological factors in the decision to seek medical care for symptoms. Medical Care, 19,693-709.

Branch, L.G., \& Nemeth, K.T. (1985). When elders fail to visit physicians. Medical Care, 23, $1265-1275$.

Calnan, M. (1984). The Health Belief Model and participation in programmes for the early detection of breast cancer: A comparative analysis. Social Science and Medicine, 19, 823 830 .

Cockburn, J., Fahey, P., \& Sanson-Fisher, R.W. (1987). Construction and validation of a questionnaire to measure the health beliefs of general practice patients. Family Practice, 4, 108-116.

Cox, C. (1986). Physician utilization by three groups of ethnic elderly. Medical Care, 24, 667676.

Cummings, K.M., Becker, M.H. \& \& Maile, M.C. (1980). Bringing the models together: An empirical approach to combining variables used to explain health actions. Journal of Behavioral Medicine, 3, 123-145.

Grimsmo, A., \& Siem, H. (1984). Factors affecting primary health care utilization. Family Practice, 1, 155-161

Hannay, D.R. (1979). The symptom iceberg. London: Routledge \& Kegan Paul.

Harrison, J.A., Mullen, P.D., \& Green, L.W. (1992). A meta-analysis of studies of the Health Belief Model. Health Education Research. Theory \& Practice, 7, 107-116.

Hibbard, J.H., \& Pope, C.R. (1986). Age differences in the use of medical care in an HMO. An application of the behavioral model. Medical Care, 24, 52-66.

Hochbaum, G.M. (1983, November). The Health Belief Model revisited. Paper presented at the Annual Meetings of the American Public Health Association, Dallas, Texas.

Janz, N.K., \& Becker, M.H. (1984). The Health Belief Model: A decade later. Health Education Quarterly, 11, 147.

John, C., Schwenk, T.L., Roi, L.D., \& Cohen, M. (1987). Medical care and demographic characteristics of 'difficult' patients. The Journal of Family Practice, 24, 607-610.

Jones, R.A., Wiese, H.J., Moore, R.W., \& Haley, J.V. (1981). On the perceived meaning of symptoms. Medical Care, 19, 710-717.

Kirscht, J.P. (1983). Preventive health behavior: A review of research and issues. Health Psychology, 2, 277-301

Leavitt, F. (1979). The Health Belief Model and utilization of ambulatory care services. Social Science and Medicine, 13A, 105-112.

Like, R., \& Zyzanski, S.J. (1986). Patient requests in family practice: A focal point for clinical negotiations. Family Practice, 3, 216-228.

Lydeard, S., \& Jones, R. (1989). Factors affecting the decision to consult with dyspepsia: Comparison of consulters and non-consulters. Journal of the Royal College of General Practitioners, 39, 495-498. 
Markides, K.S., Levin, J.S., \& Ray, L.A. (1985). Determinants of physician utilization among Mexican-Americans. A three-generation study. Medical Care, 23, 236-246.

Mullen, P.D., Hersey, J.C., \& Iverson, D.C. (1987). Health behavior models compared. Social Science and Medicine, 24, 973-981.

Rosenstock, I.M. (1974). The health belief model and preventive health behavior. Health Education Monographs, 2, 354-386.

Schrire, S. (1986). Frequent attenders - A review. Family Practice, 3, 272-275.

Strecher, V.J., McEvoy De Vellis, B., Becker, M.H., \& Rosenstock, I.M. (1986). The role of selfefficacy in achieving health behavior change. Health Education Quarterly. 13, 73-91.

Tanner, J.L., Cockerham, W.C., \& Spaeth, J.L. (1983). Predicting physicianutilization. Medical Care, 21, 360-369.

Westhead, J. (1985). Frequent attenders in general practice: Medical, psychological and social characteristics. Journal of the Royal College of General Practitioners, 35, 337-340. 


\section{CHAPTER 3}

\section{WORRY: A PARTICULAR DETERMINANT OF CONSULTATION ILLUMINATED.}

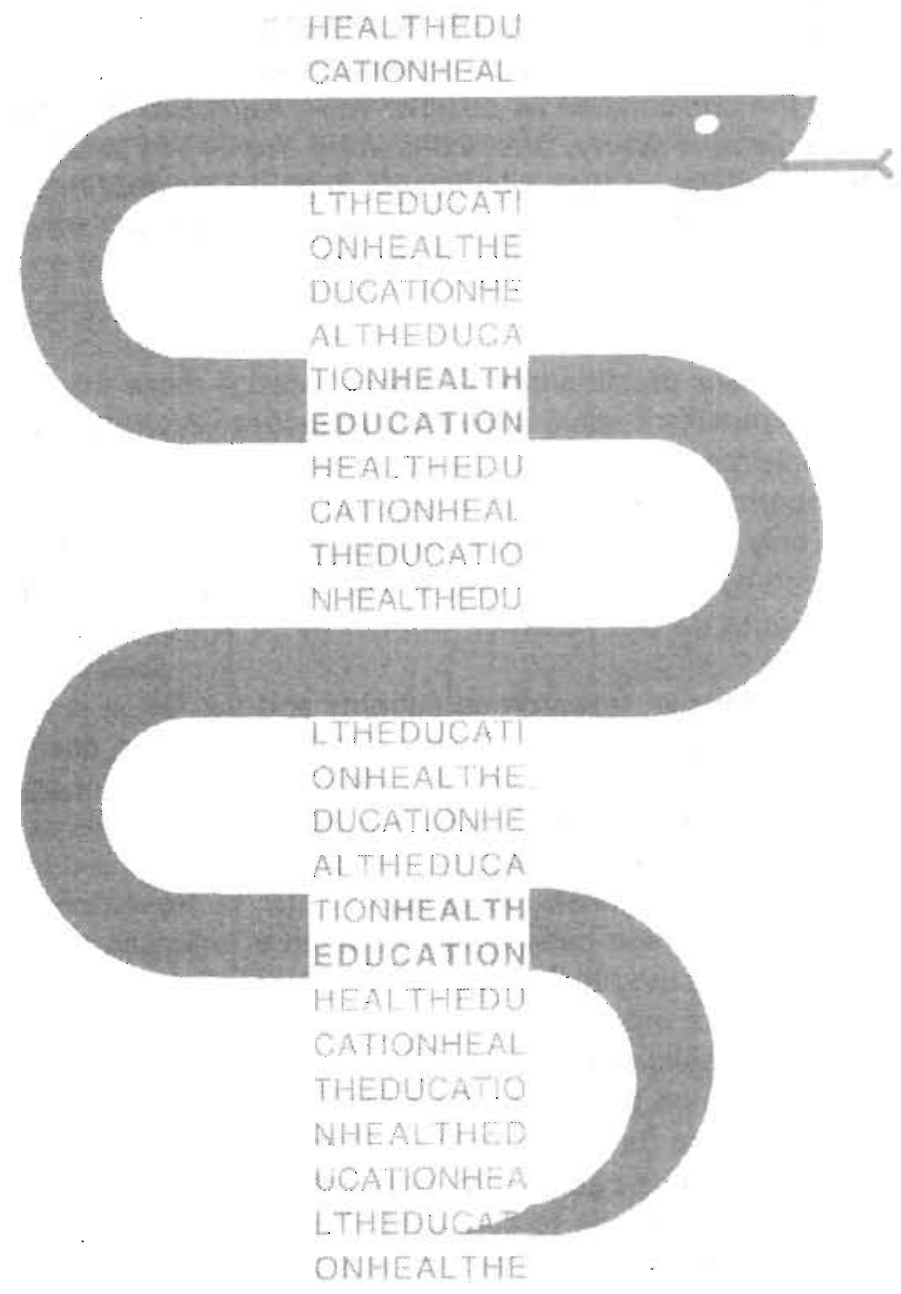

Published as: Kar, A.G.A., van de, Grinten, R.F., van de, Meertens, R.M., Knottnerus, J.A. \& Kok, G.J. (1992). Worry: A Particular Determinant of Consultation Illuminated. Family Practice, 9, 67-75. 


\section{Abstract}

In this study, exploring the worry experienced by patients in the GP waiting room and the reasons for being worried, 791 patients completed a structured questionnaire just before they consulted their GP, and afterwards. The perceptions of the patients concerning the complaint and the need for more information about the complaint played an important role in the degree of worry. Patients who want more information about the complaint are more worried than patients who do not feel they needed more information. Not surprisingly, the more serious patients perceived the complaint to be and the greater the perceived chance of serious disease, the more worried they were. General health status and frequency of consultations per year were related to the degree of general worry. According to the patients self reports, worry is almost never due to information from the mass media or from other persons, or to a concern for the consultation itself. Patients generally evaluated the consultation as positive with respect to the way their worry was discussed. The decrease in worry, after consulting the GP, in patients who were very positive about the consultation was significantly higher than that in patients who were less positive. The theoretical and practical implications of this study are discussed.

\section{INTRODUCTION}

Nowadays, general practitioners (GP) acknowledge more than previously that the patients' worry is an important issue in everyday practice. Worry caused by many apparently innocent complaints, which make up the greater part of the GPs work, is probably one of the more important reasons for consultation (De Jongh, 1987). It might be important for the GP not only to place emphasis on solving the complaint, but also to attend to the worry experienced by the patient. Attending to worry can be made especially troublesome, because patients do not put their concern into words frequently (Robinson \& Whitfield, 1987).

Despite the extensive research on patients and the GP, it is still hard to analyse patients' worry and the reasons for it (Taylor, 1986). Difficulty in designing an effective instrument to detect worry in patients is only one of the reasons for this lack of information. Nevertheless, in research into the consulting behaviour of patients, worry caused by a complaint or symptoms has been considered, and sometimes found to be a determinant of consulting the GP (Like \& Zyzanski, 1986; Schrire, 1986). Research in health education has also emphasized the relation between information or education given by the GP and the worry felt by patients (Leventhal, 1970; Sutton, 1982; Siero et al., 1984; Rippetoe \& Rogers, 1987). The level of induced worry which persuades people to act in their own best interest has been investigated, for example.

In this study we tried to explore the extent of worry of patients in the GP's waiting room, and their reasons for being worried. In the Health Belief Model (HBM) some attention is paid to the reasons people may have for health related worry (Becker, 1974). According to this model, readiness to take action for health stems, among other things, from a perceived threat of disease, coming from an individual's perception of his or her susceptibility to disease and the disease's potential severity

The HBM only considers perceptions concerning the complaint as a determinant of threat. However, we might argue that not only perceptions of the complaint, but also perceptions of care will influence worry. A person who believes that his or her complaint can be treated in an adequate way (by the GP or by self care), has less reason to be worried than a person who believes his complaint cannot be adequately treated. Furthermore, 
the information which patients have or do not have about their complaint may affect their worry. Research on the effects of health education on anxiety has generally concluded that patients become less anxious when they receive more information (Roter, 1977; Taylor, 1986). Lack of information about the complaint could lead to an increase in patient's anxiety because they may be uncertain about the complaint or about their health in general.

However, more information may not always expected to be reassuring. Information from the mass media or other people may cause worry without reason. Persons may obtain or select the wrong information, or may think it applicable to themselves while that is not the case. This study also aimed to obtain some data on the impact of mass media and other people on the patient's worry. Finally we try to gain some insight into the question of the direction of the patients' worry. Patients may be worried not only about the complaint itself, but also about the medical care and the consequences.

Thus, in the present study we examined the role perceptions of care, perceptions of the complaint and perceptions of their own level of information in worry, as well as the influence which information from the mass media and other people has on worry. In addition to this, we investigated whether background characteristics (of the person and of the complaint) influence the patient's worry (see Figure 1).

\section{Background characteristics}

Consultation variables:
Client of same GP
Consultations per year
Last consultation
Socio-psychological variables:
Health status
Usual aclion when ill
Demographic variables:
Sex
Age
Marital status
Socio-Economic Status variables:
Education
Occupation
Insurance
Income

Perceptions

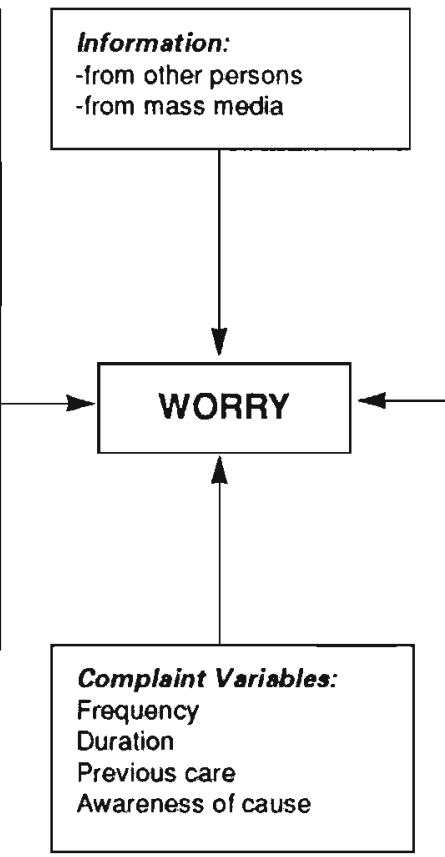

Perceptions complaint: Severity of complaint Susceptibility to disease Perceptions care: Efficacy of GP care Efficacy of self care

Perceptions information: Knowledge of complaint Need for information

Figure 1. Worry explanatory model 
The emphasis in research on the relation between information or education given by the GP and the worry of patients was a reason to investigate whether consulting the GP can contribute to a change in patient worry after consultation. To complement the results of other studies about the effects of special information given by the GP about patients concerns (Stewart et al., 1979; Boulton et al., 1984; Buchsbaum, 1986), we studied the general effect of consulting the GP on worry.

In addition to this, it was investigated whether satisfaction with the consultation is correlated with the change in patient worry after consultation. After consultation a patient who is satisfied with the way the GP discussed his or her worry will be more likely to be less worried than a patient who is dissatisfied about the discussion (Ware \& Hays, 1988).

\section{METHOD}

\section{Sample and procedure}

In the period from mid-November to mid-December 1988 a questionnaire was given to patients $(n=1000)$ in the waiting rooms of eight (urban) general practices in the province of Limburg, the Netherlands. The study was originally set up to investigate the determinants of consulting the GP (Van de Kar et al., 1992). Therefore, patients coming not of their free will, but for a medical check-up or at the invitation of the GP for a followup consultation were excluded from the study. The patients who filled in the questionnaire in the waiting room received a second questionnaire after the consultation, which could be filled in at home $(n=791)$. The present paper focuses on the parts of the questionnaire which are concerned with patient worry and the reasons for it.

\section{Questionnaires}

The first questionnaire (see annex 2), completed in the waiting room, was aimed at providing more insight into the degree of worry experienced by patients consulting the GP and the possible reasons for this. First we asked the patients about six perceptions concerning the complaint, medical care and the information about the complaint (see Figure 1). Second, an attempt was made to gain more insight into the influence of other persons and mass media on patient worry. Third, background information was asked about the complaint itself. Finally we asked patients about the degree of worry they felt in general (general worry) and the worry about the specific complaint, the consultation and the possible diagnosis (specific worry).

In the second questionnaire (see annex 3), filled in at home, data were gathered firstly, to test the effect of consulting the GP on both the general and the specific worry. and secondly to explore the relation between evaluation of discussing worry with the GP and the change in the degree of general worry and specific worry. To restrict the time and effort the patients needed to answer the questionnaire in the waiting room, we decided that all questions that could possibly be asked after the consultation should be in the second questionnaire. Therefore background characteristics were covered by the second questionnaire.

\section{Determinants of worry}

In this study we selected four categories of determinants of worry (see Figure 1).

Background characteristics. Patients were asked about their consultation behaviour: "For how long have you been consulting the same GP?". "How often did you consult the GP last year?" and "When did you last consult the GP?" Furthermore, some questions 
were concerned with their general health status and their usual reaction to complaints: "Do you feel healthy, compared to other persons of the same age?" (health status) and "What do you do first when you are not feeling too well?" lanswers ranging from nothing to using domestic remedies, to alternative medicine). Demographic variables included sex, age and marital status. Socio-economic status was based on employment status, education, income and insurance.

Complaint characteristics. Four questions were concerned with the complaint for which they were consulting the GP: "Have you had this complaint before?", "For how long has this complaint been bothering you?", "Have you tried something to treat this complaint?" and "Are you aware of the cause of this complaint?" (see Table 1).

Perceptions. Patients were asked how they perceived their complaint (severity and susceptibility), the efficacy of GP care and self care and their level of information about the complaint (knowledge about the complaint and the need for more information) (see Table 2: perceptions).

Information. Patients were asked whether talking about the complaint with other people or receiving information about the complaint from a medical programme on radio or television had worried them (see Table 2: information).

\section{Worry as a dependent variable}

The degree of general worry in this study is a combination of anxiety and uncertainty measured by the following two questions: "Do you feel uncertain or certain about your health at this moment?" and "Do you feel anxious or assured about your health at this moment?"

To elucidate to the aspect of the health problem to which the patients' worry is referred, patients were asked to what degree they were worried by the complaint itself, to what degree by the idea of consulting the GP about the complaint, and to what extent by the possible diagnosis of the complaint (see Table 2: specific worry).

To measure the effect of consulting the GP we asked all these questions on worry in the first as well as in the second questionnaire.

\section{Satisfaction with the discussion of the worry}

To gain an impression of how the respondents experienced the consultation, two questions, on five point scales, were asked about the discussion of worry during consultation: "Did you have the opportunity to discuss your uncertainty about your health with the GP?" and "Did you have the opportunity to discuss your anxiety about your health with the GP?" The anchors of the scales were 'far too little' and 'more than enough'.

\section{Statistical analysis}

Only the responses given by the 791 respondents who completed both questionnaires were used for data analysis. Cross-tabulations were drawn concerning the background characteristics, including the complaint characteristics, of the respondents, their perceptions, information from other persons and mass media and worry. Hierarchical multiple regression analysis was used to examine the contribution of these three categories of determinants to the prediction of worry before consulting the GP.

Repeated measures analysis of variance (MANOVA) was used to examine the effect of consulting the GP. The effect was measured by comparing the scores on worry before and after consultation. The difference between these scores is considered here as the effect of consulting the GP. 
Finally, repeated measures analysis of variance was also used to examine whether patients who were relatively satisfied with the way the GP had discussed their concern showed a greater change in worry than patients who were relatively dissatisfied in this respect.

The way in which discussing concern is related to the change of worry was explored by comparing scores on worry before and after consultation of very satisfied patients with those of less satisfied patients.

\section{RESULTS}

\section{Background characteristics of analysis sample}

Table 1 presents the background characteristics of the 791 selected respondents. One of the more interesting results is that most respondents stated that typically they treated their complaints without consulting a GP (65.9\%). Most of the respondents were under 45 years of age $(66.2 \%)$. Most of the 791 respondents had completed secondary education ( $44.7 \%)$, had a full-time or part-time paid job $(44.2 \%)$, and earned a net income between 1500 and 2500 guilders per month (40.3\%).

Almost half of the respondents had experienced the complaint for which they were consulting the GP more than once. The duration of the complaint was generally less than 3 months $(71.6 \%$ ). Almost half of the patients had tried to treat the complaint on their own with domestic remedies $(49.2 \%)$ and without really knowing the cause of the complaint $(39.4 \%)$.

\section{Perceptions concerning the complaint, care, and information}

Table 2 presents the means and standard deviations of how the respondents perceived the complaint, care and information before consulting the GP. On the average, severity of the complaint was perceived as moderate and susceptibility to a serious disease as very small. The efficacy of GP care was perceived as moderate and the efficacy of self care as very small. Respondents indicated that they had insufficient knowledge and needed more information about the complaint. 
Table 1. Background characteristics of analysis sample $(n=791)$

Consultation variables $(\%)$ :

\begin{tabular}{|c|c|c|c|c|c|}
\hline \multicolumn{2}{|l|}{ Client of same GP } & \multicolumn{2}{|c|}{ Consulations per year } & \multicolumn{2}{|l|}{ Last consultation } \\
\hline$<1$ year & 05.8 & times & 03.8 & $<1$ week & 25.1 \\
\hline 1 - 5 year & 29.3 & 1 - 5 times & 70.8 & $\geq 1 w k \quad-\leq 2 w k s$ & 16.4 \\
\hline 6.10 year & 20.0 & $6-10$ times & 18.4 & $>2$ wks $-\leq 3$ mths & 29.9 \\
\hline $11-20$ year & 26.8 & $>10$ times & 07.0 & $>3$ mths - $\leq 1$ year & 22.2 \\
\hline$>20$ year & 18.2 & & & $>1$ year & 06.5 \\
\hline
\end{tabular}

Socio-psychological variables $(\%)$ :

\begin{tabular}{llll}
\hline Health Status & & Usual action when ill \\
very healthy & 10.0 & none & 03.7 \\
healthy & 44.0 & self care & 65.9 \\
average & 35.1 & medical care & 24.8 \\
unhealthy & 09.5 & other & 05.7 \\
very unhealthy & 01.4 & &
\end{tabular}

Demographic variables $(\%)$ :

\begin{tabular}{lrllll}
\hline Sex & \multicolumn{3}{c}{ Age } & Marital status \\
male & 40.6 & $\leq 25$ years & 25.0 & unmarried & 25.3 \\
female & 59.4 & $26-35$ years & 21.2 & living with someone & 04.9 \\
& & $36-45$ years & 20.0 & married & 60.5 \\
& & $46-55$ years & 14.3 & widowed & 04.8 \\
& $56-65$ years & 11.4 & divorced & 04.4 \\
& $>65$ years & 08.1 & & \\
& & & & \\
& &
\end{tabular}

Socio-Economic Status variables $(\%)$ :

\begin{tabular}{lllllr}
\hline Education & & Occupation & & \multicolumn{2}{c}{ Income in guilders p.m. } \\
elementary & 37.2 & unpaid & 40.6 & $\leq 1500$ & 26.7 \\
secondary & 44.7 & unemployed & 02.4 & $>1500-\leq 2500$ & 40.3 \\
higher & 18.1 & retired/incapacitated & 12.8 & $>2500-\leq 3500$ & 16.6 \\
& & paid & 44.2 & $>3500$ & 16.4
\end{tabular}

\section{Insurance}

public 70.9

private 29.1

\section{Complaint variables $(\%)$ :}

\begin{tabular}{|c|c|c|c|c|c|}
\hline Awareness of cause & & Previous care & & Duration & \\
\hline very well aware & 13.5 & none & 14.0 & $<1$ week & 21.9 \\
\hline aware & 14.5 & self care & 49.2 & $\geq 1 w k \quad-\leq 2 w k s$ & 24,4 \\
\hline unsure & 39,4 & medical care & 25.9 & $>2$ wks $-\leq 3$ mths & 25.3 \\
\hline not aware & 19.8 & other & 10.9 & $>3$ mths $-\leq 1$ year & 14.8 \\
\hline totaliy unaware & 12.6 & & & $>1$ year & 13.7 \\
\hline Frequency & & & & & \\
\hline never & 36.0 & & & & \\
\hline once & 17.6 & & & & \\
\hline more than once & 46.4 & & & & \\
\hline
\end{tabular}




\section{Information from other people and mass media}

When questionned about the extent to which they became worried as a result of talking to others or receiving information from the mass media, the majority of the respondents $(60.1 \%)$ answered that they discussed the complaint with other people, although on average, worry caused by talking to others was less than moderate.

Only very few respondents $(7.8 \%)$ stated that they received information from the mass media. Worry among these respondents caused by information from a medical programme, however, was moderate.

\section{Worry of the respondents before consulting the GP}

The degree of experienced worry by the respondents is indicated by the means and standard deviations of general worry and specific worry (Table 2). The average degree of worry is just about moderate. The respondents said that they were worried most by the complaint and not much by the idea of consulting the GP about it.

\section{Table 2. Means (M) and standard deviations (SD) of perceptions, information and worry $(n=791)$}

\section{Questions}

Perceptions before consultation $(n=791)$ :

Do you think your complaint is serious? ${ }^{a}$

Do you think your complaint has to do with a serious disease?

Do you think the GP can treat your complaint?

Do you think that you could have treated your complaint yourself? ${ }^{b}$

Do you think you know enough about your complaint?

\section{Information}

Did you discuss your complaint with other people? ${ }^{d}(n=475)$ :

Are you worried by what these people said about the complaint? ${ }^{e}$

Are you worried by what these people said about the idea of consulting the GP? ${ }^{e}$ 


\section{Satisfaction with the discussion of worry}

The two questions for the satisfaction with the discussion of the worry correlated highly $(r=0.78, P<0.001)$. Patients generally evaluated the discussion of the worry with their GP as positive ( $n=383, M=3.93$ on a 5 -point scale). For further analysis the respondents who did discuss their worry with the GP were divided into two groups at the median of the two question scale of satisfaction: one group of very satisfied patients $(n=292)$ and one group of less satisfied patients $(n=91)$.

\section{Hierarchical multiple regression analysis of general worry}

Hierarchical multiple regression analysis was used to examine the contribution of the background and complaint characteristics, health beliefs and information to the prediction of general worry. Standardized regression weights ( $(3), R^{2}$ change, and the $F$ values are shown in Table 3.

The variables entered in block 1, background characteristics, accounted for approximately $14 \%$ of the variance in the degree of general worry. The main predictor variable at this first step is the frequency of consultations per year. Patients who consulted the GP between one and five times per year were more worried than patients who have had more than 10 consultations per year. In addition health status made a significant contribution: patients who thought they were less healthy than others of the same age, were more worried. Sex and duration of the complaint were background characteristics that also explained some variance. Woman experienced more worry than men, and the longer the duration of the complaint, the more worried patients were.

Table 3. Hierarchical multiple regression analysis of general worry $(n=791)$

\begin{tabular}{|c|c|c|c|c|}
\hline \multirow[t]{2}{*}{ Block } & \multirow[t]{2}{*}{ Variable } & \multicolumn{3}{|c|}{ General worry } \\
\hline & & B & $R^{2}$ & $\mathbf{F}$ \\
\hline \multirow[t]{5}{*}{1} & background characteristics & & 0.14 & $31.71^{* \cdots}$ \\
\hline & Sex & $0.08^{*}$ & & \\
\hline & Health status & $-0.24^{* \cdots}$ & & \\
\hline & Duration complaint & $0.11^{* *}$ & & \\
\hline & Consultation per year & $0.15^{* \cdots *}$ & & \\
\hline \multirow[t]{7}{*}{2} & Porceptions & & 0.37 & $45.09^{\cdots *}$ \\
\hline & Knowledge of complaint & $-0.03^{n s}$ & & \\
\hline & Efficacy of self care & $0.04^{\mathrm{ns}}$ & & \\
\hline & Severity complaint & $0.27^{* * *}$ & & \\
\hline & Efficacy of GP care & $-0.03^{\mathrm{ns}}$ & & \\
\hline & Susceptibility & $0.30^{* * *}$ & & \\
\hline & Need for information & $0.12^{\cdots \cdots}$ & & \\
\hline \multirow[t]{3}{*}{3} & Information & & 0.38 & $38.13^{\cdots *}$ \\
\hline & from other persons & $0.06^{\mathrm{ns}}$ & & \\
\hline & from mass media & $0.03^{n s}$ & & \\
\hline
\end{tabular}

$* P<0.05, * P<0.01, * * P<0.001$ 
Block 2 of the analysis produced a substantial increase over the previous block in the amount of explained variance. The variables in this block, the perceptions, accounted for $23 \%$ of the variance in the degree of general worry, after controlling for the effect of the background characteristics. The perceived chance that the complaint is due to a serious disease was significantly related to general worry: the greater the patients perceived this chance, the more worried they were. The perceived severity of the complaint significantly predicted general worry: the more serious patients perceived the complaint to be, the more worried they were. To a lesser extent, need for information is a predictor for general worry. The greater the need for information, the more worry patients experience.

The variables in block 3 added very little to the amount of variance explained $(1 \%)$. Information from others and mass media were not significant predictors for general worry.

Hierarchical multiple regression analysis was used to examine the contribution of the background and complaint characteristics, perceptions and information to the prediction of specific worry. There were only few notable differences compared the results of hierarchical regression analysis of general worry (see Table 4).

Table 4. Hierarchical multiple regression analysis of specific worry $(n=791)$

\begin{tabular}{|c|c|c|c|c|c|c|c|c|c|}
\hline \multirow[t]{2}{*}{ Block } & \multirow[t]{2}{*}{ Variable } & \multicolumn{3}{|c|}{ Complaint } & \multicolumn{3}{|c|}{ Consultation } & \multicolumn{2}{|c|}{ Diagnosis } \\
\hline & & $\bar{B}$ & R2 & $\mathbf{F}$ & $\bar{B}$ & R2 & $\mathbf{F}$ & R2 & $\mathbf{F}$ \\
\hline \multirow[t]{5}{*}{1} & Background & & 0.05 & $11.04 * *$ & & 0.05 & $9.95^{* * *}$ & 0.07 & $14.72^{* * *}$ \\
\hline & Sex & $0.06^{\text {ns }}$ & & & \multicolumn{2}{|c|}{$0.11^{*}$} & & $0.03^{\text {ns }}$ & \\
\hline & Health status & $-0.12^{* *}$ & & & \multicolumn{2}{|l|}{$-0.06^{n s}$} & & $-0.11^{* *}$ & \\
\hline & Duration complaint & $0.11^{\cdots}$ & & & \multicolumn{2}{|l|}{$0.10^{\circ *}$} & & $0.13^{\cdots \cdots}$ & \\
\hline & Consultation p.y. & $0.09^{*}$ & & & \multicolumn{2}{|l|}{$0.10^{* *}$} & & $0.14^{* * *}$ & \\
\hline \multirow[t]{7}{*}{2} & Percoptions & & 0,31 & $33.79^{* *}$ & & 0.13 & $11.70^{*}$ & 0.27 & $28.38^{\cdots *}$ \\
\hline & Knowledge complaint & $-0.03^{n s}$ & & & \multicolumn{2}{|l|}{$-0.08^{*}$} & & $-0.06^{n s}$ & \\
\hline & Efficacy of self care & $0.06^{\text {ns }}$ & & & \multicolumn{2}{|l|}{$0.03^{n s}$} & & $0.02^{\text {ns }}$ & \\
\hline & Severity complaint & $0.27^{\cdots}$ & & & \multicolumn{2}{|l|}{$0.08^{\prime \prime}$} & & $0.17^{\circ \cdots}$ & \\
\hline & Efficacy of GP care & $0.03^{\text {ns }}$ & & & \multicolumn{2}{|l|}{$0.01^{\mathrm{ns}}$} & & $-0.08^{*}$ & \\
\hline & Susceptibility & $0.31^{* \cdots}$ & & & \multicolumn{2}{|l|}{$0.20^{* *}$} & & $0.24^{* * *}$ & \\
\hline & Need for information & $0.75^{* * *}$ & & & $0.09^{\circ}$ & & & $0.20^{* \cdots}$ & \\
\hline \multirow[t]{3}{*}{3} & Information & & 0.31 & $28.59^{* * *}$ & & 0.14 & $10.30^{* \cdots}$ & 0.28 & $24.13^{* * *}$ \\
\hline & from other persons & $0.05^{\mathrm{ns}}$ & & & \multicolumn{2}{|c|}{$0.05^{n s}$} & & $0.05^{n s}$ & \\
\hline & from mass media & $0.04^{\mathrm{ns}}$ & & & \multicolumn{2}{|l|}{$0.06^{\text {ns }}$} & & $0.05^{n s}$ & \\
\hline
\end{tabular}

* $P<0.05, " * P<0.01$, *** $P<0.001$

A factor which seems to be a better predictor for worry about the consultation than general worry, or worry about the complaint or the diagnosis, was sex: female patients were more worried about the consultation than male patients. Notably, but perhaps not surprisingly, health status and the severity of the complaint was not strongly rela- 
ted to worry about the consultation; and the variable knowledge about the complaint could explain more variance of worry about the consultation than of general worry. The more patients said they knew about their complaint, the less worried they were. Need for information also seems to be related to the worry about the diagnosis. The more worried patients, were those who perceived a greater need for information.

We were also interested in the patients who stated that they were worried or very worried about their health $(n=158)$. Consequently, we investigated whether these patients' worry was determined by factors other than the 'normal' patient's worry. Hierarchical multiple regression analysis was used to examine the contribution of the background and complaint characteristics, perceptions and information to the prediction of the worry of these very worried patients. Only for general worry we did find some significant results (probably due to the small number and consequent low statistical power). Notable differences were that for block 1 health status and duration of the complaint were more important than consultations per year. For block 2 severity and need for information were important, while susceptibility was not.

\section{Effect of consulting the GP on worry}

Repeated measures analysis was used to examine the effect of consulting the GP on the degree of worry expressed by patients. Multivariate analysis showed that there was a significant multivariate main effect for consultation (before/after) $(F(4,787)=99.55$, $P<0.001$ ). The results of the univariate analysis and the mean scores are presented in Table 5. The mean scores in Table 5 show that after the consultation the respondents were generally less worried. Worry about the complaint, consultation and diagnosis was also less after the consultation.

Table 5. Effect of consulting the GP on worry $(n=791)$

$\begin{array}{ll}\text { Univariate analysis }(\mathrm{df}=1,790) & \begin{array}{l}\text { Mean scores }^{\mathrm{a}} \\ \text { consultation }\end{array}\end{array}$

\begin{tabular}{llll}
\hline Dependent variables & F & Before & After \\
\hline General worry & $264.85^{* * *}$ & 2.87 & 2.42 \\
Specific worry: & & & \\
worry about complaint & $291.95^{* * *}$ & 2.90 & 2.23 \\
worry about consultation & $067.76^{* * * *}$ & 2.16 & 1.85 \\
worry about diagnosis & $077.78^{* * *}$ & 2.44 & 2.12 \\
\hline
\end{tabular}

*** $P<0.001$

a $1=$ low, 5 = high

\section{Effect of consultation and satisfaction with discussing worry}

Finally, the degree of the respondents satisfaction about the discussion of the worry with the GP during consultation was taken into account. For further analysis the respondents were divided into two groups at the median of the two question scale of satisfaction with the discussion of the worry: one group of very satisfied patients $(n=292)$ 
and one group of less satisfied patients $(n=91)$. Very satisfied patients were compared with less satisfied patients with respect to their changes in worry after consultation.

A repeated measures analysis of variance yielded a multivariate significant main effect of consulting the GP $(F(4,378)=35, P<0.001)$ and a multivariate significant main effect for satisfaction with the discussion of worry $(F(4,378)=3.28, P<0.01)$.

More interesting. however, is the multivariate significant interaction effect for consultation (before/after) $\times$ satisfaction $(F(4,378)=4.93, P<0.001)$. Only the univariate tests of general worry and worry about the complaint were significant. The mean scores in Table 6 show that for both groups general worry and worry about the complaint have decreased. There was no significant difference in these aspects of worry before consultation, but after consultation the very satisfied patients were significantly less worried than the less satisfied patients.

Table 6. Interaction effect of consultation (before/after) $x$ satisfaction ( $n=383$ )

$\begin{array}{ll}\text { Univariate F-tests }(\mathrm{df}=1,381) & \begin{array}{l}\text { Mean } \text { scores }^{\mathrm{a}} \\ \text { Consultation }\end{array}\end{array}$

\begin{tabular}{|c|c|c|c|c|}
\hline Dependent variables & $\mathbf{F}$ & Satisfaction & Before & After \\
\hline General worry & $16.12^{\cdots \cdots}$ & - & $3.37^{x}$ & $3.10 \mathrm{~V}$ \\
\hline Specific worry: & & + & $3.28^{x}$ & $2.60^{2}$ \\
\hline Worry about complaint & $04.41^{* \cdots}$ & $\begin{array}{l}- \\
+\end{array}$ & $\begin{array}{l}3.48^{x} \\
3.32^{x}\end{array}$ & $\begin{array}{l}2.89 y \\
2.43^{2}\end{array}$ \\
\hline
\end{tabular}

Worry about consultation

$03.78^{\text {n.s. }}$

Worry about diagnosis

$00.05^{n .5}$

*** $P<0.001$

a $1=$ low, 5 = high Means with different superscripts differ at the $5 \%$ significance level from each other.

\section{DISCUSSION}

In this study we have tried to acquire more insight into the degree of worry felt by patients in the GP's waiting room, and into the causes of this worry. The respondents in this study, did not seem to be extremely worried; they were generally worried most by the complaint and hardly worried by the consultation itself. Most patients discussed the complaint with other people but talking to others did not seem to be a source of worry itself. Few patients received information from the mass media about the complaint and those who did did not perceive the mass media as a source of their worry.

The perceptions of patients concerning the complaint and the need for more information about the complaint played an important role in the degree of worry. The more serious patients thought the complaint was, the more worried they were. The greater their perception of the chance that they had a serious disease, the more worried they were. 
Perceptions concerning the complaint could explain worry more than, for instance, background characteristics. Information from other sources, like talking to others or information from the mass media, played no part in explaining worry of patients.

We were also interested in the question whether consulting the GP can reduce patient worry. Some studies have measured the relation between special information given by the GP and the extent of worry in patients (Leventhal, 1970; Sutton, 1982; Siero et al., 1984; Rippetoe \& Rogers, 1987). In this study we tried to test the effect of consulting the GP in general on worry. Consulting the GP had a positive effect on the patient's worry, especially on worry about the complaint. However, some reservation is warranted with respect to the conclusion that consultation reassures patients. Since patients consulting the GP were not compared to patients not consulting the GP le.g. the lack of a control group), the reduction in worry might possibly be attributed to factors other than the consultation. On the other hand, one may argue that the consultation is probably an important factor in the reduction of worry, because satisfaction with the way worry is discussed in the consultation seems to affect the patients' reduction in worry: worry was decreased more in patients who said that their concern was discussed satisfactorily with the GP than in patients who felt their worry was not satisfactorily discussed. This analysis also revealed that patients' satisfaction with the way their worry is discussed in the consultation is generally positive. These results concur with those in a study of satisfaction in hospital patients (Ware \& Hays, 1988).

In summary, the variables susceptibility and severity, which are considered the main elements of worry or perceived threat in the Health Belief Model, indeed seem to play a prominent role in the general worry experienced by patients who consult the GP. A result which may be considered important because of its practical as well as its theoretical concerns, is that a perceived lack of information may lead to worry in patients. Furthermore, not surprisingly, several background characteristics which all seem to have a relationship with the patient's health status (including duration of the complaint and number of consultations per year) seem to determine patient worry. A salient finding is that perceptions of the possibilities of care (GP care or self care) does not seem to influence the extent to which patients feel worried. We had rather expected that patients who feel that their complaint can be treated adequately would feel less worried than patients who feel that their complaint cannot adequately be treated.

What implications do these results have for the GP in daily practice? First, patient worry does not seem to be extremely high and patients seem to worry primarily about the complaint itself. Fortunately, patients are almost never worried by the idea of consulting the GP about the complaint. Female patients seem to be a bit more worried about the consultation itself. For the GP it is important to know that worry can be explained by patient characteristics, but more by the way in which patients perceive their complaint. Apart from the patients' perceptions of the severity of the complaint and the susceptibility to a serious disease, the need for more information is an important dimension in patient worry.

Second, we may conclude that if a GP discusses the complaint and the concomitant worry to the patient's satisfaction, this may lead to a decrease in worry.

The most important limitation of this study is its explorative and correlational character. Because we used self report data of patients, we are strongly dependent on the insight patients have of their own worry and the causes thereof. Furthermore, due to the correlational nature of this study, we may not draw any conclusions about the direction of causality of the relations found. 


\section{REFERENCES}

Becker, M.H. (Ed.). (1974). The Health Belief Model and personal health behavior [Special issue]. Health Education Monographs, 2, 326-473.

Boulton, M.G., Griffiths, J., Hall, D., Mclntyre, M., Oliver, B., \& Woodward, J.(1984). Improving communication: A practical programme for teaching trainees about communication issues in the general practice consultation. Medical Education, 18, 269-274.

Buchsbaum, D.G. (1986). Reassurance reconsidered. Social Science and Medicine, 23, $423-427$.

Jongh, T. de (1987). Ongerustheid, een eerstelijnsziekte. Medisch Contact, 42, 828-830

Kar, van de, A.G.A., Knottnerus, J.A., Meertens, R.M., Dubois, V., \& Kok, G.J. (1992). Why do patients consult the general practitioner? Determinants of their decision. British Journal of General Practice, 42, 313-316.

Leventhal, H. (1970). Findings and theory in the study of fear communications. In L. Berkowitz (Ed.), Advances in Experimental Social Psychology: Vol. 5. (pp. 119186). New York: Academic Press.

Ley, P. (1982). Giving information to patients. In J. Eiser (Ed.), Social Psychology and Behavioral Medicine (pp. 339-373). Chicester: Wiley.

Like, R., \& Zyzanski. S.J. (1986). Patient requests in family practice: A focal point for clinical negotiations. Family Practice, 3, 216-228.

Rippetoe, P.A., \& Rogers, R.W. (1987). Effects of components of protection-motivation theory on adaptive and maladaptive coping with a health threat. Journal of Personality and Social Psychology, 52, 596-604.

Robinson, E.J., \& Whitfield, M.J. (1987). Participation of patients during general practice consultations: Comparison between trainees and experienced doctors. Family Practice, 4. 5-10.

Roter, D.L. (1977). Patient participation in the patient-provider interaction: The effects of patient question asking on the quality of interaction, satisfaction and compliance. Health Education Monographs, 5, 281-315.

Schrire, S. (1986). Frequent attenders - A review. Family Practice, 3, 272-275.

Siero, S., Kok, G.J., \& Pruyn, J. (1984). Effects of public education about breast cancer and breast self-examination. Social Science and Medicine, 18, 881-888.

Stewart, M.A., McWhinney, I.R., \& Buck, C.W. (1979). The doctor/patient relationship and its effect upon outcome. Journal of the Royal College of General Practitioners, 29, 77-81.

Sutton, S.R. (1982). Fear arousing communications: A critical examination of theory and research. In J. Eiser (Ed.), Social Psychology and Behavioral Medicine (pp. 303-337). Chicester: Wiley.

Taylor, S.E. (1986). Health Psychology. New York: Random House.

Ware, J.E., \& Hays, R.D. (1988). Methods for measuring patient satisfaction with specific medical encounters. Medical Care, 26, 393-402. 


\section{CHAPTER 4}

\section{CHANGES IN PATIENTS' HEALTH BELIEFS AFTER CONSULTING THE GENERAL PRACTITIONER}

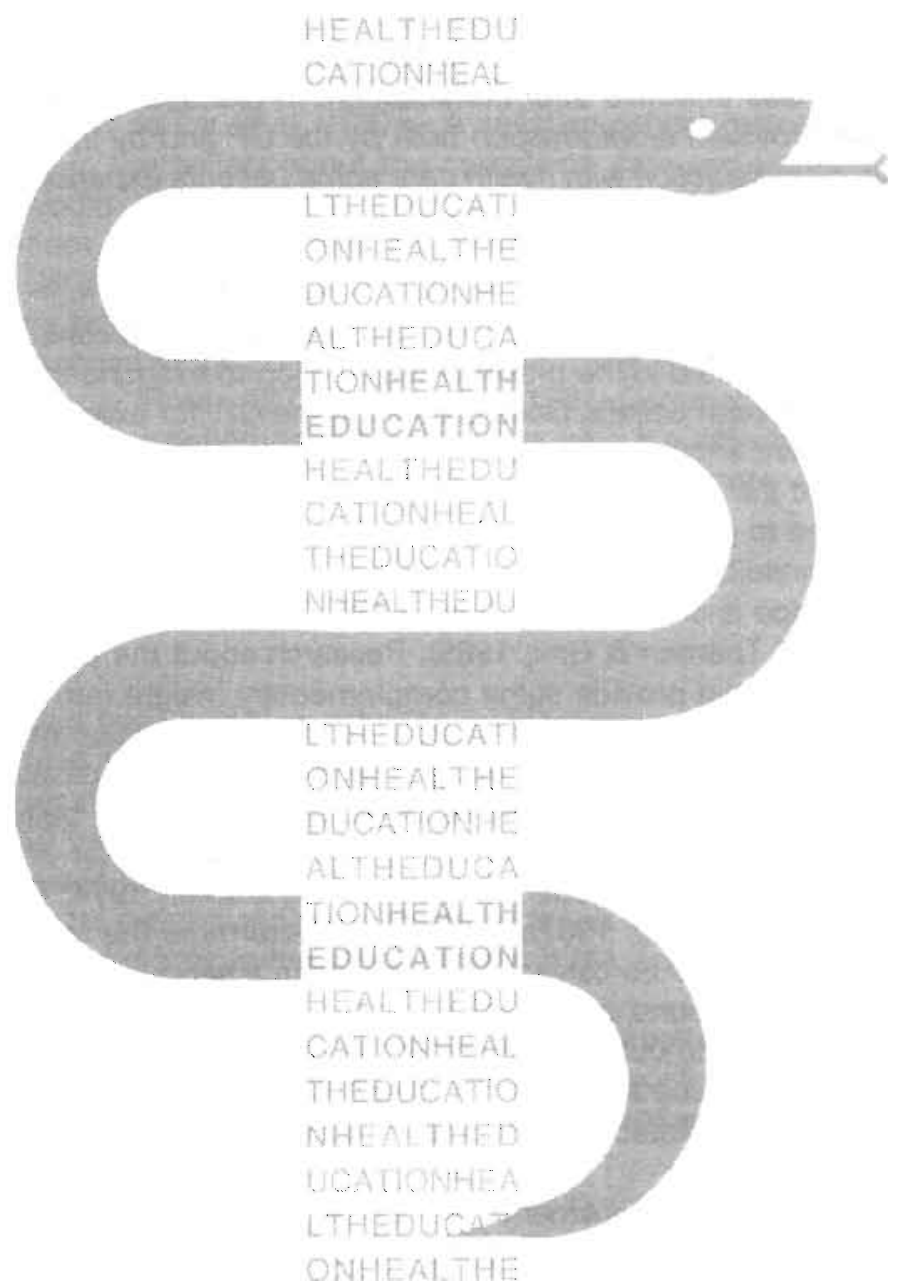

Kar, van de, A.G.A., Meertens, R.M., Kok, G.J., Knottnerus, J.A.

Submitted for publication to British Journal of General Practice. 


\section{Abstract}

The purpose of this study is to describe patients' views about complaint, care and information before consulting the GP and to discover whether patients change their views after consulting the GP. The results show that a consultation leads to significant changes in the beliefs about the complaint, the level of information one has and the care the GP can provide. After consultation, patients think that their complaint is less serious and that the chance that they suffer from a serious disease is smaller than before consultation. Patients' need for more information seems to have decreased after consulting the GP. Patients perceive GP care as less effective after than before consultation. However, this effect seems to be qualified by the extent to which patients feel satisfied with the GP consultation. The perception very satisfied patients have of the efficacy of GP care remains the same before and after consultation. Less satisfied patients, however, perceived GP care as less effective after consultation. In discussing the results we argue that improving the provision of information both by the GP and by the patient may partly solve the relative dissatisfaction with health care some patients experience.

\section{INTRODUCTION}

Following an earlier study into the health beliefs of people consulting the GP (Van de Kar et al., 1992a), we tried in the present investigation to examine the effect of consulting the GP on these health beliefs. Does consulting the GP, for example, lead patients to feel that they now have enough information about the complaint? Do they feel more reassured with respect to the severity of the complaint after the consultation? Other researchers have already tried to gain insight into the communication aspects of consultations and into the effect of consulting the GP on several specific outcomes such as the patient's satisfaction, knowledge and compliance (Ley, 1976; Carter et al., 1982; Ley, 1982a; Ley, 1982b; Helman, 1985; Toemen \& Grol, 1989). Research about the effect of GP consultation on health beliefs could provide some complementary insight into the aspects of GP care. Furthermore, this kind of research could lead to an explanation of the behaviour of the patient after the consultation (e.g. seeking other health care, medical compliance).

Elsewhere we have extensively reported on what health beliefs may be considered as important determinants of consulting the GP (Van de Kar et al., 1992a). As a basis we took the Health Belief Model (HBM) (reviews Becker, 1974; Rosenstock, 1974; Hochbaum, 1983; Mullen et al., 1987), and tried to determine the role of the perceived severity of the complaint, the perceived susceptibility to a serious disease, perceived efficacy of GP care and background characteristics in the decision to consult the GP.

We also tried to find out how significant the effect of so-called 'cues to action' is in this decision. The term 'cue to action' as used in the HBM refers to an event that triggers an individual's health related behaviour, for example an article in a newspaper, or the illness of a friend.

In addition to the HBM elements, we examined the role of some other possible determinants of consulting the GP: perceived efficacy of self care, perceived knowledge of the complaint and the perceived need for information about the complaint. The results of the study indicated that the factors 'efficacy of self care' and 'need for information' as well as most factors based on the HBM (efficacy of GP care, perceived severity, cues to action) are important determinants of consulting the GP.

The aim of the present study is to discover whether patients changed the health beliefs mentioned after consulting the GP. In view of the fairly innocent nature of most 
complaints the GP is generally dealing with, it was hypothesized that after consulting the GP patients would perceive their complaint as less serious and the chance of a serious disease would be perceived as smaller. The perceptions of the possibilities of care given by the GP are expected to increase, and patients are expected to perceive more possibilities to treat the complaint by themselves. It was predicted that, by consulting the GP. patients would perceive their knowledge about the complaint as more adequate and would feel less need for more information (Bain, 1977; Boreham \& Gibson, 1978; Krantz et al., 1980).

During consultation a GP often cannot give the expected attention to a patient because of telephone calls or lack of time. Patients may feel neglected in such a situation. Probably these patients will leave the consulting room dissatisfied, thinking that even the GP cannot listen to them or answer their questions. In our view, the satisfaction of the patient with the consultation may be expected to influence the amount of change in health beliefs. Satisfaction is the expression of a patient evaluating several expectations of the consultation (Van de Kar et al., 1992b). A satisfied patient may experience a greater or different change in the beliefs about the complaint, care and information than a dissatisfied patient would. Why would a patient's view, for instance about the complaint, change, if the patient in question feels that there was not enough time to discuss the complaint, or the GP did not give enough information about the complaint? Conditions like having enough time or being able to ask all the questions they have, or talking about nonmedical aspects attached to the complaint could determine whether patients consider the consultation satisfactory (Roter, 1977; Smith et al., 1981; Comstock et al., 1982; Dimatteo \& DiNicola, 1982). So, we hypothesize that patients who are satisfied with the consultation change their health beliefs in a positive way more than patients who are not satisfied with the consultation.

\section{METHOD}

\section{Sample}

In the period from mid-November to mid-December 1988, a questionnaire was given to patients ( $n=1000$ ) in the waiting rooms of eight (urban) general practices in the province of Limburg, the Netherlands. Patients who came for a medical check up or at the invitation of the GP for a follow-up consultation were excluded from the study. The only inclusion criterion used in this research was that patients had come to consult the GP of their own free will. No restrictions were made as far as the type of complaint was concerned. The patients who filled in the questionnaire in the waiting room received a second questionnaire after the consultation.

The sample in the present study consisted of 791 patients who consulted the GP and completed the first questionnaire in the waiting room of the GP, before seeing the $\mathrm{GP}$, and who sent back the second questionnaire, which was completed at home after the consultation.

\section{Beliefs about complaint, care and information}

When patients decide to consult the GP they have their reasons. The determinants of consulting the GP (background characteristics and health beliefs) were explicitly investigated in a previous study (Van de Kar et al., 1992a).

In the first questionnaire (see Annex 2), filled in by patients just before consulting the GP, patients were asked about their health beliefs concerning the complaint (severity and susceptibility), the efficacy of care (GP care and self care) and information (knowledge 
about the complaint and the need for more information). After the consultation patients answered the same questions, with slight textual differences, in the second questionnaire (see Table 2 and Annex 3).

\section{Satisfaction with the consultation by the patient}

Considerable attempts have been made to improve questionnaires to measure patient satisfaction with doctors and medical care services. In general patients tend to indicate that they are (very) satisfied with all health care services, perhaps because this answer is the socially desirable one (Smith et al., 1981; Ware \& Hays, 1988; Van de Kar et al., 1992b). In the present study the patients' satisfaction with the consultation was determined by seven evaluative characteristics of the consultation. The evaluative questions were asked in the second questionnaire (after consultation) on a five point scale.

In this study satisfaction of the consultation was specified for two aspects. The first concerned the satisfaction of the patient with the opportunity to communicate with the GP about their complaint, measured by the questions: "Did you have the opportunity to ask all the questions you had about your complaint?", "Was there enough time to discuss your complaint?" and "Could you make clear which complaint you consulted the GP for?"

The second aspect related to satisfaction with the information given by the GP concerning the complaint, diagnosis and treatment measured by the questions: "If necessary, did the GP inform you about the causes of your complaint?", "Did the GP inform you about the diagnosis of your complaint" and "Did the GP inform you about the treatment of your complaint?"

\section{RESULTS}

Possible sample bias resulting from patients who did not send back the second questionnaire was evaluated by univariate comparisons between health beliefs (before consultation) of respondents $(n=791)$ and non-respondents $(n=209)$. This analysis revealed no significant differences between respondents and non-respondents on the health beliefs. We therefore conclude that non-response may probably be excluded as a source of bias in generalizing the results of the study.

\section{Background characteristics of analysis sample}

Table 1 presents the background characteristics of the respondents. The majority of them were female $(59.4 \%)$, younger than 45 years $(66.2 \%)$ and married $(60.5 \%)$. The socio-economic status of the majority of the respondents can be described as having completed secondary education (44.7\%), a paid job (44.2\%), as being insured with a public health insurance fund $(70.9 \%)$ and by having a net income between 1500 and 2500 guilders per month (40.3\%). 


\section{Demographic variables $(\%)$ :}

\begin{tabular}{lrrlll}
\hline Sex & \multicolumn{1}{c}{ Age } & & Marital status \\
male & 40.6 & $\leq 25$ years & 25.0 & unmarried & 25.3 \\
female & 59.4 & $26-35$ years & 21.2 & living with someone & 04.9 \\
& & $36-45$ years & 20.0 & married & 60.5 \\
& & $46-55$ years & 14.3 & widowed & 04.8 \\
& $56-65$ years & 11.4 & divorced & 04.4 \\
& $>65$ years & 08.1 & &
\end{tabular}

\section{Socio-Economic Status variables $(\%)$ :}

\begin{tabular}{llllll} 
Education & & Occupation & & \multicolumn{2}{c}{ Income in guilders p.m. } \\
elementary & 37.2 & unpaid & 40.6 & 51500 & 26.7 \\
secondary & 44.7 & unemployed & 02.4 & $>1500-52500$ & 40.3 \\
higher & 18.1 & retired/fncapacitated & 12.8 & $>2500 \cdot \leq 3500$ & 16.6 \\
& & paid & 44.2 & $>3500$ & 16.4
\end{tabular}

\section{Insurance}

public

private

\section{Effect of consulting the GP on health beliefs}

The means and standard deviations of patients' perceptions of the complaint, care and information before consulting the GP are presented in Table 2. On average, respondents perceived the severity of the complaint as moderate and the likelihood of serious illness as low. The efficacy of GP care was perceived as moderate and the efficacy of self care as low. Furthermore, the respondents indicated that they had insufficient knowledge and felt they needed more information.

Repeated measures analysis of variance (MANOVA) was used to examine the effect of consulting the GP. The effect of consultation was measured by comparing the scores on the health beliefs beforehand, in the waiting room, with the scores on the same health beliefs, after the consultation. Multivariate analysis showed that there is a significant multivariate main effect for consulting the GP which on a univariate level is significant for all health beliefs except for the perception of self care $(F(6,785)=141.59, P<0.001)$ (see Table 2). Compared to perceptions before the consultation, severity ratings were lower after the consultation, as was the probability of serious illness. Surprisingly, the respondents perceived the efficacy of GP care a little lower. As expected, however, they perceived the efficacy of self care a little higher after the consultation. The perceptions about information show that the respondents are not sure they know enough about the complaint and still want some more information about the complaint. 


\section{Mean scores \\ Consultation}

Health beliefs $(\mathrm{df}=1,790)$

Before After

\begin{tabular}{lllll}
\hline Questions before/after consultation & F & & Before & After \\
\hline $\begin{array}{l}\text { Severity } \\
\text { Do you (now) think your complaint is serious? } \\
\text { Susceptibility }\end{array}$ & & $328.41^{\text {*** }}$ & 3.16 & 2.57 \\
$\begin{array}{l}\text { Do you (now) think your complaint has to do with a serious disease? } \\
\text { Efficacy GP care }\end{array}$ & $093.17^{* *}$ & 2.06 & 1.78 \\
$\begin{array}{l}\text { Do you (now) think the GP can treat your complaint? } \\
\text { Efficacy self care }\end{array}$ & $016.61^{* *}$ & 3.51 & 3.36 \\
$\begin{array}{l}\text { Do you (now) think that you could have treated your complaint yourself? } \\
\text { Knowledge complaint }\end{array}$ & $002.52^{\text {ns }}$ & 1.96 & 2.02 \\
$\begin{array}{l}\text { Do you think you (now) know enough about your complaint? } \\
\text { Need for information } \\
\text { Do you (now) need more information about your complaint? }\end{array}$ & $287.31^{* *}$ & 2.79 & 3.61 \\
\hline
\end{tabular}

a 5 -point scale from $1=$ not serious at all to $5=$ very serious

b 5-point scale from $1=$ certainly not to $5=$ most certainly

c 5-point scale from $1=$ very little to $5=$ more than enough

$* P<.0 .01$

\section{Satisfaction after consultation}

The seven questions for the satisfaction of consultation formed an internally consistent scale (Alpha $=0.89$ ). To get a more detailed view of the origins of general (dis)satisfaction with the consultation we were especially interested in the two aspects related to satisfaction, 'opportunity to communicate' and 'information'. The first aspect included the three questions about the opportunity to discuss the complaint and the time they had to discuss it. On average, the respondents were very satisfied in this respect (Mean score is 4.27 on a 5 -point scale).

The second aspect included the four questions about the information given by the GP concerning the complaint, diagnosis and treatment. On average, the respondents were satisfied about the information given by the GP during consultation (Mean score is 3.89 on a 5 -point scale). The respondents seemed, however, to be more satisfied about their opportunities to give information and ask questions than about the information given by the GP $(T=17.53, P<0.001)$.

\section{Effect of consultation and general satisfaction}

How did satisfaction with the consultation influence the changes in the patients beliefs? Repeated measures analysis of variance was used to answer this question. Respondents were divided in two groups at the median of the seven question scale of satisfaction: one group of very satisfied patients $(n=337)$ and one group of less satisfied patients $(n=454)$. Very satisfied patients were compared with less satisfied patients with respect to their changes in health beliefs after consultation. 
Multivariate analysis showed that there is a multivariate significant main effect for consultation $(F(6,784)=158.18, P<0.001)$ and satisfaction in general $(F(6,784)=19.50, P<$ $0.001)$. The consultation itself as well as the general level of satisfaction seem to affect the perceptions of the complaint, efficacy of GP care and information. The perceived possibilities for self care do not seem to be influenced by the consultation or the level of satisfaction with the consultation.

How did very satisfied patients and less satisfied patients differ with respect to changes in health beliefs from before to after consultation? There is a multivariate significant interaction effect for consultation (before/after) $\times$ satisfaction $(F(6,784)=15.23, P<$ $0.001)$. Satisfaction with the consultation significantly affected the changes in all perceptions after consultation except for the perception of self care (see Table 3).

Table 3. Interaction effect consultation (before/after) x general satisfaction ( $n=791)$

\begin{tabular}{ll}
\hline Univariate F-tests $(d f=1,789)$ & $\begin{array}{l}\text { Mean scores } \\
\text { Consultation }\end{array}$ \\
&
\end{tabular}

$\begin{array}{llll}\text { Dependent variables } & F & \text { Satisfaction } & \text { After }\end{array}$

\begin{tabular}{|c|c|c|c|c|}
\hline \multirow[t]{2}{*}{ Severity } & $12.09^{* \cdots}$ & . & $3.17^{\mathrm{a}}$ & $2.67^{\mathrm{b}}$ \\
\hline & & + & $3.15^{a}$ & $2.43^{C}$ \\
\hline \multirow[t]{2}{*}{ Susceptibility } & $04.28^{\prime \prime}$ & $\cdot$ & $2.13^{a}$ & $1.90^{C}$ \\
\hline & & + & $1.96^{\mathrm{b}}$ & $1.62^{\mathrm{d}}$ \\
\hline \multirow[t]{2}{*}{ Efficacy GP care } & $14.69^{* * *}$ & - & $3.39^{\mathrm{a}}$ & $3.13^{c}$ \\
\hline & & + & $3.67^{b}$ & $3.69^{b}$ \\
\hline Efficacy self care & $00.03^{n . s}$ & & & \\
\hline \multirow[t]{2}{*}{ Knowledge complaint } & $66.89^{* * *}$ & - & $2.72^{\mathrm{a}}$ & $3.21^{\mathrm{C}}$ \\
\hline & & + & $2.90^{b}$ & $4.15^{\mathrm{d}}$ \\
\hline \multirow[t]{2}{*}{ Neod for information } & $46.55^{* \cdots *}$ & - & $3.96^{\mathrm{a}}$ & $3.18^{b}$ \\
\hline & & + & $3.95^{\mathrm{a}}$ & $2.52^{c}$ \\
\hline
\end{tabular}

$* P<.05, * P<0.1, * * P<.001$

a 1 = low, 5 = high. Means with different superscripts differ at the $5 \%$ significance level from each other.

The mean scores for the interaction in Table 3 show that for both satisfaction groups the perceived severity and the perceived susceptibility to a serious disease has decreased. After consultation the perceived susceptibility was significantly lower for the patients evaluating the consultation as very positive than for the less positive patients. However, this also seems to be the case before the consultation, though before consultation the differences between the groups are smaller. Only after consultation was the perceived severity of the complaint significantly different. The very satisfied patients had a lower perception of the severity after consultation than the less satisfied patients. 
The mean scores show also that patients evaluating the consultation as very positive perceived the same degree of efficacy of GP care before and after the consultation, while patients evaluating the consultation as less positive perceived GP care as less effective after the consultation. This result seems to indicate that a decrease of perceived efficacy of GP care after consultation may be attributed to patients who are not satisfied with the consultation.

With regard to the perceptions of information before and after the consultation, the results show that for both groups the perception of knowledge increased and the need for information decreased. After consultation the perceived knowledge about the complaint was significantly higher for the patients evaluating the consultation as very positive than for the less positive patients. However, about the same pattern was found before the consultation, though before consultation the difference between both groups was smaller. The perceived need for information about the complaint was significantly different between groups only after consultation. The very satisfied patients perceived less need for information after consultation than the less satisfied patients.

\section{DISCUSSION}

In this study patients' health beliefs, before consulting the GP, were very moderate. The complaints were perceived as not really serious. Patients think the GP probably cannot do very much for them, and they do not know much about the complaint. Consulting the GP, however, seems to change the health beliefs. In this study it was found that the consultation leads to a significant change, however small, in the beliefs about the complaint, the GP care and the information. The effect of the consultation on the perceptions concerning the complaint and the information was as we expected. After consultation patients thought their complaint was less serious and the chance that they suffered from a serious disease was perceived as smaller

The effect of consultation on the perceptions concerning the information suggests the opposite of what has generally been concluded in previous research. In effect studies, researchers have reported that patients want more information when they consult the GP but that the increase of knowledge after consulting the GP is very small (Boreham \& Gibson, 1978). Researchers have suggested that patients forget most of the information given during the consultation (Fletcher, 1979). However, this study shows that patients after consulting the GP at least feel that they have gained knowledge, though perhaps their actual increase in knowledge may be very small.

The effect of consultation on the perception of the efficacy of GP care was opposite to our expectations. After consultation patients perceived the GP care as less effective than before. Perceptions about self care seemed not to be affected by the consultation. An explanation can be found in the sample of this study. The respondents were all patients who consulted the GP and their perception about self care had probably reached the bottom when they decided to consult the GP. Still we have assumed that a GP nowadays would promote self care during consultation. There is a possibility that the GP actually did promote self care, but patients did not interpret it as self care anymore but more as following doctor's advice

The effect of satisfaction of patients on the changes in perceived GP care seems to indicate that the way patients evaluate the consultation is maybe an important dimension in explaining the change in perceptions. Very satisfied patients perceive the same degree of efficacy of GP care before and after consultation. Patients who are less satisfied 
(especially with their opportunities to discuss their complaints with the GP), however, perceived GP care as less effective after consultation. In addition, the perceived severity of the disease, the perceived susceptibility to a serious disease, the perceived knowledge of the complaint and the need for information experienced showed stronger change after consultation for satisfied than for dissatisfied patients.

Before summarizing the main conclusions and formulating some practical implications of this study, we would like to point out some methodological limitations. First, we want to highlight that, considering the design used, one should not draw conclusions too easily about the effects of the consultation on health beliefs: we did not compare patients who did consult the GP with patients who did not. Because of the lack of a control group. changes in health beliefs may be due to factors other than the consultation itself, for example duration of time.

On basis of some other findings, however, one might argue that probably the consultation itself is at least partly responsible for the changes in health beliefs: how patients evaluated the consultation seemed to have an influence on the extent of change in their health beliefs. It seems reasonable to assume that, when (perceived) characteristics of the consultation influence the amount of change in beliefs, the consultation plays a role in the changes.

A second limitation of this study is its observational character. Because of the correlational nature of the findings we may not be too confident in the conclusion that some patients change their health beliefs more strongly because they are more satisfied with the consultation. Other variables (e.g. characteristics of the GP or of the patient) may cause both the greater satisfaction and the greater changes in health beliefs. The finding that very satisfied patients differ from less satisfied patients before the consultation on several health beliefs, suggests that these groups of patients do indeed vary on more variables than satisfaction with the consultation only.

And now the main conclusions and practical implications of this study will be presented. In general, there seems to be a positive effect of consulting the GP and patients are satisfied about the opportunity to communicate and about the information given by the GP during the consultation. Careful consideration needs to be given, however, to the fact that the effect of consulting the GP can be less prominent in some respect for the less satisfied patients. The fact that the effect of consulting the GP on health beliefs seems to be tied to the satisfaction of the consultation, suggests that the consultation itself should be a primary concern for GP and patient. This could imply that patients have to prepare for their consultation, for example, by making notes of what they want to know. GPs could pay more attention to the information they give in response to the patient's request for information. Recognizing that consultation is at least a two-way process, interventions in which the GP is prepared to ask about patients' health beliefs and the patient is prepared to express his or her expectations during consultation may be developed and evaluated in future research. Improving the provision of information by both the GP and the patient may reduce the concomitant problems of relative dissatisfaction with health care (Fletcher, 1979; Stewart et al., 1979; Pendleton \& Hasler, 1983; Taylor, 1986). 


\section{REFERENCES}

Bain, D.J.G. (1977). Patient knowledge and the content of the consultation in general practice. Medical Education, 11, 347-350.

Becker, M.H. (Ed.). (1974). The Health Belief Model and personal health behavior [Special issue]. Health Education Monographs, 2, 326-473.

Boreham, P., \& Gibson, D. (1978). The informative process in private medical consultations: A preliminary investigation. Social Science and Medicine, 12, 409-416.

Carter, W.B., Inui, T.S., Kukull, W.A., \& Haigh, V.H. (1982). Outcome-based doctor-patient interaction analysis: II. Identifying effective provider and patient behavior. Medical Care, 20, 550-566.

Comstock, L.M., Hooper, E.M., Goodwin, J.M., \& Goodwin, J.S. (1982). Physician behaviors that correlate with patient satisfaction. Journal of Medical Education, 57, 105-112.

DiMatteo, M.R., \& DiNicola, D.D. (1982). Achieving patient compliance. The psychology of the medical practitioner's role. New York: Pergamon Press.

Fletcher, C. (1979). Towards better practice and teaching of communication between doctors and patients. In G. McLachlan G (Ed.). Essays on Current Research. Twelfth Series, Nuffield Provincial Hospitals Trust: Mixed Communications Problems and Progress in Medical Care (pp. 3-41). Oxford: University Press.

Helman, C.G. (1985). Communication in primary care: The role of patient and practitioner explanatory models. Social Science and Medicine, 20, 923-931.

Hochbaum, G.M. (1983, November). The Health Belief Model revisited. Paper presented at the Annual Meetings of the American Public Health Association, Dallas, Texas.

Kar, van de, A.G.A., Knottnerus, J.A., Meertens, R.M., Dubois, V., \& Kok, G.J. (1992a). Why do patients consult the general practitioner? Determinants of their decision. British Journal of General Practice, 42, 313-316.

Kar, van de. A.G.A., Grinten, van der, R., Meertens, R.M., Kok, G.J., \& Knottnerus, J.A. (1992b) Worry: A particular determinant of consultation illuminated. Family Practice, 9, 67-75.

Krantz, D.S., Baum, A., \& Wideman, van M. (1980). Assessment of preferences for self-treatment and information in health care. Journal of Personality and Social Psychology, 5 , 977-990.

Ley, P. (1976). Towards better doctor-patient communication. In A. Bennett (Ed.), Communications Between Doctors and Patients (pp. 77-98). London: Oxford University Press.

Ley, P. (1982a). Satisfaction, compliance and communication. British Journal of Clinical Psycho$\log y, 21,241-254$.

Ley, P. (1982b). Giving information to patients. In J. Eiser (Ed.), Social Psychology and Behavioral Medicine (pp. 339-373). Chicester: Wiley.

Mullen, P.D., Hersey, J.C., \& Iverson, D.C. (1987). Health behavior models compared. Social Science and Medicine, 24, 973-981.

Pendleton. D., \& Hasler, J. (Eds.). (1983). Doctor-Patient Communication. New York: Academic Press.

Rosenstock, I.M. (1974). The health belief model and preventive health behavior. Health Education Monographs, 2, 354-386.

Roter, D.L. (1977). Patient participation in the patient-provider interaction: The effects of patient question asking on the quality of interaction, satisfaction and compliance. Health Education Monographs, 5, 281-315.

Smith, C.K., Polis, E., \& Hadac, R.R. (1981). Characteristics of the initial medical interview associated with patient satisfaction and understanding. The Journal of Family Practice, 12, 283-288.

Stewart, M.A., McWhinney, I.R., \& Buck, C.W. (1979). The doctor/patient relationship and its effect upon outcome. Journal of the Royal College of General Practitioners, 29, 77-81. 
Taylor, S.E. (1986). Health Psychology. New York: Random House.

Toemen, T., \& Grol, R. (1989). De huisarts geeft voorlichting: reacties van patienten na het consult. In M. Cuisinier, J. van Eijk, R. Grol, R. Jonkers (Eds.). Patiëntenvoorlichting in de eerste lijn (pp. 92-100). Den Haag: Care - Uitgeverij voor Gezondheidsbevordering.

Ware, J.E., \& Hays, R.D. (1988). Methods for measuring patient satisfaction with specific medical encounters. Medical Care, 26, 393-402. 


\section{CHAPTER 5}

\section{DETERMINANTS OF CONSULTING THE GEINERAL PRACTITIONER AND PATIENTS' WORRY An experimental and an observational study compared.}

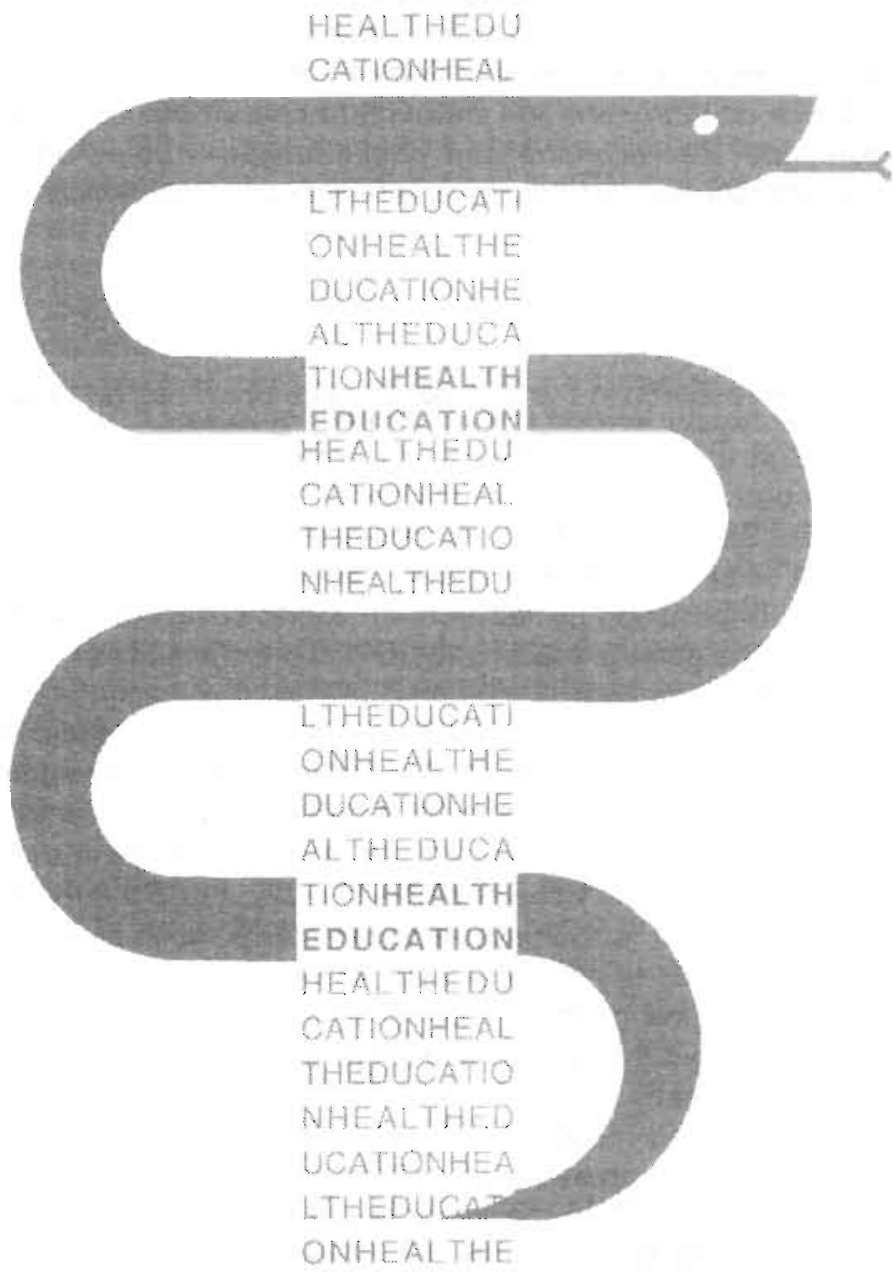

Kar, van de, A.G.A., Meertens, R.M., Kok, G.J., Knottnerus, J.A.

Submitted for publication to Health Education Research: Theory \& Practice. 


\section{Abstract}

Social science research in general practice often has an observational character. Although such research has the advantage of being conducted in a 'real life' situation, a disadvantage is that it is difficult to determine causal relations. 'Scenario studies' can yield complementary information, since scenario studies take place in an artificial situation, allowing cause-effect relations to be tested. An observational study in the waiting rooms of eight general practices provided insight into the determinants of consulting the GP. To investigate causality, however, we conducted two scenario studies. Results showed that in general the scenario studies yielded the same results, but now not only in a correlational sense, as the observational study conducted earlier. Low perceived efficacy of self care seemed to cause high intention to consult the GP. However, some discrepancies in results were found as well. In the scenario studies we found that coincidental information had a strong influence on worry and the intention to consult the GP, a result not found in real life. We conclude that scenario and observational studies are complementary methods, and that scenario studies may be an efficient and economical method to explore a relatively new research area.

\section{INTRODUCTION}

Social science research in the general practice often has an observational character. Although such research has the advantage of being conducted in a 'real life' situation, a disadvantage is that it is very difficult to determine causal relations. However, one would of ten like to derive such causal relations for theoretical and/or practical purposes (Becker et al., 1977). 'Scenario studies' perhaps can yield complementary information for correlational studies since in such an artificial situation cause-effect relations can be tested. In this paper the information gained from an earlier observational study on the determinants of consulting the general practitioner (GP) and the results of two scenario studies on the same subject are compared.

Until now, the factors that determine whether individuals will or will not consult the GP have not been intensively explored. General focus on the interpersonal relationship between GP and patient resulted in neglect of the reasons why patients consult the GP in the first place. In an overview of studies directed at determining the circumstances under which individuals use medical services, McKinlay (1972) stated that more work is needed on the relative importance of 'socio-psychological factors' such as knowledge, attitudes, beliefs, and 'triggers' or cues to perform health related activities. Such research, aimed at assessing socio-psychological or other determinants of using medical services, could be very useful in encouraging patients to make more effective use of the medical services: unnecessarily consulting costly health services and unnecessary delay - which may lead to more complex treatment and more costs - may be prevented. For example, if perceived efficacy of GP care were an important (causal) determinant of GP consultation, emphasizing the effectiveness of the GP in the treatment of certain complaints may be expected to 'prevent' unnecessary delay. In contrast, if, for example, health educators were to deemphasize the effectiveness of the GP, or state explicitly that the GP can do nothing in case of particular complaints, unnecessary consultation may be prevented Westhead, 1985).

In a previous study we conducted a survey in the waiting rooms of eight general practices (Van de Kar et al., 1992a). The aim of the study was to gain insight into the determinants of consulting the GP. The questions, based on literature and theories about use of 
health services (Becker \& Maiman, 1975; Leavitt, 1979; Berkanovic et al., 1981; Janz \& Becker, 1984; Mullen et al., 1987) or health behavior in general fell in six main categories:

1. background characteristics;

2. perceptions of the complaint (e.g. severity and susceptibility);

3. perceptions of care (e.g. effectiveness of the GP care, perceived efficacy of self care);

4. perceptions of information (e.g. knowledge about the complaint and need for more information);

5. barriers to consulting the GP (financial or practical, e.g., time or transport); 6. social influences on the decision (advice from others to consult the GP, acquain-

tance with others having the same complaint, and their decision to consult the GP or not, information from the media).

Two groups of patients answered the questions: one group which consulted the GP about a complaint, and one group who also had a second complaint but did not (and would not) consult the GP for that complaint. Results showed that the perceived effectiveness of the care that may be expected from the GP and perceived effectiveness of self care determined the decision of patients to consult their GP. These results confirm the results of previous research of primary health care use (Grimsmo \& Siem, 1984; Like \& Zyzanski, 1986; Schrire, 1986; Meininger, 1986; Berwick et al., 1987). Perceptions of efficacy of GP care and self care were more important than perceived severity and susceptibility. The decision to consult the GP about a complaint will depend on whether patients feel that the GP can treat their complaint and on whether patients feel able to treat this complaint on their own. Further, as might be expected, advice from others was an important cue in the decision to consult the GP.

In addition patients were questioned about worry and some possible reasons for this, for it was expected that worry plays an intermediary role between determinants and GP consultation (Leventhal, 1970; Sutton, 1982). Results showed that patients' worry was related to the perceived severity of the complaint and the perceived susceptibility (Van de Kar et al., 1992b). Surprisingly, however, it hardly mattered how effective people thought the GP would be in managing their complaint: with respect to the worry patients feel, perceptions of the complaint were more important than perceptions of care.

The correlational results of the observational study do not permit the conclusion that, for exampe, high perceived efficacy of GP care makes people go to the GP. Strictly speaking, it is possible that people who consulted the GP had higher perceived efficacy because they wanted to justify their consultation. That is, consulting the GP causes higher perceived efficacy of GP care rather than the other way around. It is equally possible that an unknown third factor would cause both the GP consultation and a high perceived efficacy of GP care. Determining the cause-effect relation of worry on the one side and perceptions of complaint and care on the other pose the same problems. Does the severity of a complaint cause worry or does a worried patient perceive the complaint as more serious?

To gain some insight in the causal direction of the correlations found, we conducted two scenario studies. These studies were designed to detect whether the intention to consult the GP and worry are (causally) affected by perceptions of the complaint, and perceptions of care. Two perceptions of a complaint (severity and susceptibility) and two perceptions of care (GP care and self care) were selected as independent variables. The question was whether these four perceptions are causally related to patients' worry and the intention to consult the GP. On basis of the correlations found in the observational study, it was hypothesized that if a complaint is perceived as more serious and/or the 
susceptibility to a particular disease is perceived as higher, a patient will be more worried and more inclined to consult the GP. Further it was hypothesized that if care given by the GP is expected to be very effective, a patient will be more inclined to consult the GP than when no effective care is expected from the GP. Exactly the opposite effect was expected for self care: if self care is evaluated as more effective, a patient will be less inclined to consult the GP and less worried than when self care is expected to be ineffective.

\section{METHOD OF SCENARIO STUDY 1}

\section{Design}

In study 1 a story was presented to 160 students. The story described a person reading an article about a certain disease in the morning paper. The susceptibility of the person to the disease, the severity of the disease, the expected effectiveness of GP care and self care were systematically varied on two levels between stories. We asked subjects to imagine themselves in the position of the person in the story, and to indicate how worried they would feel and how strong their inclination would be to consult their GP. Thus, a randomized 2 (Susceptibility) $\times 2$ (Severity) $\times 2$ (Efficacy GP care) $\times 2$ (Efficacy self care) factorial design was used.

\section{Subjects and procedure}

Health Sciences student volunteers participated in this study. In all 160 students, 95 women and 65 men, cooperated in this study during class. Subjects completed the questionnaire for their individually assigned experimental condition in about ten minutes. The proportion of men and women was about equal in every condition.

\section{Manipulation of the independent variables}

In every version of the story the four independent variables were systematically manipulated on a high or low level. For example, the chance of having the disease was described in one version as very high (high susceptibility) and in another version as very low (low susceptibility). In a brief introduction subjects were asked to imagine that they would find themselves in the following situation:

During breakfast you are reading the morning paper at ease. Today the newspaper contains a supplement about health and illness. One article attracts your attention and you start to read. The article states that there is a relation between symptoms $X$ and $Y$ and disease $A$.

The chance of having disease $A$ is, given the symptoms $X$ and $Y$, very high (very low).

This disease is been described as (not) very serious.

You think that the GP could (not) offer effective medical help in a situation like this and that you could (not) fight this disease by yourself.

Suddenly you realise that you happen to have the symptoms described.

\section{Intention to consult the GP and worry}

The dependent variables are worry of the subjects and the intention of the subjects to consult the GP. The subjects had to answer the following questions on seven point scales: "Would you be worried in such a situation?" and "In a situation like this, would you intend to consult your GP?" The anchors of the scales were 'no, certainly not' and 'yes, certainly'. 
The last question included the rider that one should not consider the financial consequences in deciding whether or not to consult the GP; further it was added that one should not take into account what others, like parents, partner and friends, would think of the decision. These additions were made to assure that financial costs or opinions of others (factors not of our primary interest) would not interfere with the decision to consult the GP.

To gain more insight into the decision to consult the GP, we added an extra question. Subjects were asked to give the reasons for their decision. They could choose among the following five alternatives describing possible attitudes of persons in the situation described.

1. Health is something you have under your own control. Therefore it is best to find a solution for this situation by yourself.

2. The GP is there to give medical care in every situation. I would decide to consult the GP.

3. I would like to forget such situations as soon as possible. So I would pick up my normal activities as soon as possible.

4. I consider several aspects in the described situation and I am not sure what to do. I decide to consult the GP after all to be sure.

5. Other, such as .....

\section{RESULTS AND DISCUSSION SCENARIO STUDY 1}

\section{Manipulation checks}

We thought it useful to check whether subjects picked up the information in the story as intended. To check whether subjects perceived the susceptibility to the disease as depicted in the story, subjects were asked to give a percentage estimate of the relation between symptoms $X$ and $Y$ and disease $A$. This check showed that the high and low susceptibility levels differed in the intended direction. The mean score for the "high susceptibility' condition was $63.7 \%$ and $25.4 \%$ for the 'low susceptibility' condition ( $T=$ $11.68, P<0.001)$.

To check the manipulation of efficacy of GP care subjects were asked to give a percentage estimate of the chance that the GP could give adequate medical care. The mean score for the 'high efficacy of GP care' condition was $64.5 \%$ and $28.9 \%$ for the 'low efficacy of GP care' condition (T=10.07, $P<0.001)$.

The manipulation of the efficacy of self care was checked by the question: "What is your estimate in percentage of the chance that you can fight the disease by yourself?" The mean score for the 'high efficacy of self care' condition was $44.4 \%$ and $22.4 \%$ for the 'low efficacy of self care' condition ( $T=5.96, P<0.001$ ). Thus, all the manipulations appear to have succeeded.

\section{Analysis}

A multivariate analysis of variance was executed to examine the effects of the independent variables on worry and intention to consult the GP. The analysis yielded a significant multivariate main effect for susceptibility $(F(2,143)=3.11, P<0.05)$. The level of susceptibility significantly affected worry $(F(1,144)=5.28, P<0.02)$, but not the intention to consult the GP $(F(1,144)=3.75, P<0.06)$. Subjects in the high-susceptibility condition reported a greater overail level of worry than subjects did in the low-susceptibility condition (for means, see Table 1). This effect of susceptibility on worry, but not on intention to consult the GP, is in line with the results of the observational study. 
Further, the analysis yielded a significant multivariate main effect for severity $(F(2,143)=16.57, P<0.001)$. The level of perceived severity significantly affected worry $(F(1,144)=33.37, P<0.001)$ and the intention to consult the $G P(F(1,144)=7.12, P<$ 0.01 ). If they thought a complaint was very serious, subjects were significantly more worried and more inclined to say they would consult the GP than when they thought the complaint in question was not serious (for means, see table 1). The effect of severity on both worry and intention was expected on basis of the results of our earlier study.

We found a third significant multivariate main effect for efficacy of self care $(F(2,143)=3.51, P<0.03)$. This paralleled the results of the observational study. The level of efficacy significantly affected the intention to consult the $\operatorname{GP}(F(1,144)=6.57, P<0.01)$, but not worry $(F(1,144)=3.24, P<0.07)$. Subjects who were told to imagine that they could not fight the disease themselves were significantly more inclined to consult the GP than subjects who thought they could fight the disease by themselves. It is noteworthy that in real life also, intention to consult the GP was affected by perceived efficacy of self care whereas worry was not. The analysis revealed no significant interaction effects.

In contrast to what we expected on basis of the observational study, the perceived efficacy of GP care did not affect the decision to consult the GP $(F(2,143)<1, P=$ n.s.). It is notable that the effect of the expected efficacy of GP care on the intention to consult the GP (found in the observational study) has also been found in other studies (Grimsmo \& Siem, 1984; Like \& Zyzanski, 1986). It may be argued, as an explanation of the discrepancies between the experimental and the observational study, that the need for information from the GP was stronger in the artificial situation in this study than in the 'real life' situation. This could be the case because the disease in question was a fictitious one, thus a disease on which one could have no information. This explanation finds support in the results from the extra question which asked subjects why they answered the questions as they did: $57 \%$ of the subjects indicated that they would consult the GP for more information. In both the observational study and the scenario studies there seems to be no effect of perceived efficacy of GP care on worry.

\section{Table 1. Mean scores of the significant determinants of worry and intention to consult the $G P(n=160)$}

\begin{tabular}{llll}
\hline & & Worry & Intentiona $^{\mathbf{a}}$ \\
\hline & & & \\
Susceptibility & Low & 4.00 & 4.09 \\
Severity & High & 4.46 & 4.55 \\
& Low & 3.65 & 4.00 \\
Efficacy of self care & High & 4.81 & 4.64 \\
& Low & 4.41 & 4.63 \\
& High & 4.05 & 4.01 \\
\hline
\end{tabular}

a $1=$ low, 7 = high

\section{SCENARIO STUDY 2}

The objective of study 2 is slightly different from that in the previous one. Whereas in the first study we tried to replicate some findings of the observational study 
conducted earlier, in the second study we tried to find some evidence of the existence of a relationship not found in the observational study.

In the observational study we asked patients to report whether other people in their social environment happened to have the same symptoms or complaints as they were experiencing themselves. These questions originated from an interest mainly engendered by anecdotes; anecdotes about runs on GPs after a TV broadcast on an exceptional disease; anecdotes about medical students who have to stop their studies because they think they have every disease that is dealt with in class (Schramm \& Roberts, 1977; Donohew et al., 1988). These anecdotes (probably every reader will know one version or another) led us to hypothesize that coincidental information, like knowing someone with the same symptoms or complaint, would sometimes lead patients to consult the GP.

Tversky and Kahneman (1974) deal with the mechanism behind the influence of coincidental information on behavior. They state that individuals often will use heuristics to estimate chances (for instance the chance they have a disease). One of these heuristics is the 'availability heuristic'; to estimate the probability of a certain event, one tries to recall the times the event already has happened (to others and/or to oneself). Though this often is a quite good basis for a guess, obviously the 'availability heuristic' can lead to biases too. Not only can coincidental information affect the guess, but also the salience or emotionality of events. Salient memories or affect-laden memories (for instance the death of a friend) may be expected to be recalled better than unspectacular ones (a friend catching a cold) (Nisbett \& Ross, 1980). In the observational study, however, we did not find that patients consulted the GP about a complaint more often if they were acquainted with patients having the same complaints or symptoms than individuals who did not (intend to) consult the GP about their complaint. The lack of such an influence of coincidental information on consulting the GP may have been the result of the small number of patients who reported that they knew individuals with similar symptoms or complaints. Thus, though it may be concluded that coincidental information in reality is not a very strong determinant of consulting the GP, it sometimes might have an influence.

In study 2 , besides information about the severity of the disease and the susceptibility to the disease and 'real' information about the statistical chance of success of the medical treatment, we also provided some 'coincidental' information about a friend who happened to have the same symptoms and in whom the medical treatment did or did not succeed. It was hypothesized that if the medical treatment has a high statistical chance of success, a patient will be less worried and more inclined to consult the GP. Further we hypothesized that coincidental information has an effect on worry and intention to consult the GP; we expected that worry would be higher when the friend died during the operation, than when the operation on the friend was a success. It must be noted that this last hypothesis assumes that people's worry and intention to consult the GP do not always have rational causes: whatever the statistical, objective chances of successful treatment are, we assume coincidental information has an influence. Thus, it may be expected that when the medical treatment has a small statistical chance of success and a friend died during the operation, a patient will be very worried. What will be the effect of extreme worry on the patients' intention to consult the GP? On the one hand it could be hypothesized that the greater the worry, the stronger the intention to consult the GP. On the other hand, it might be hypothesized that extreme anxiety will lead to denial of the symptoms, and result in the decision not to consult the GP (Siero et al., 1984). The effect of extreme anxiety on the intention to consult the GP was investigated. 


\section{METHOD OF SCENARIO STUDY 2}

\section{Design}

In study 2 another story was presented to 160 subjects, this time describing a person watching television. Besides the influence of susceptibility and severity, it was tested whether coincidental information influenced worry and intention to consult the GP. Further 'objective' statistical information on the probability of success or failure of the medical treatment was varied between conditions. A randomized 2 (susceptibility) $\times 2$ (severity) $\times 2$ (objective information) $\times 2$ (coincidental information) factorial design was used to test our hypotheses.

\section{Subjects and procedure}

The procedure in study 2 was the same as in the first. We presented the story to the same students. This second study was not announced during the first study. Subjects were also randomly assigned to the second study, so the combinations of both studies were random.

\section{Manipulation of the independent variables}

The story reads as follows:

In your television magazine you read that a health programme is being broadcast this evening. The programme seems interesting and you decide to watch the programme. The programme is devoted to the disease $B$.

This disease is not contagious, and occurs independently of manner of living and environmental factors.

Three symptoms are discussed. There is a relation between these symptoms and disease $B$. The chance of having disease $B$ is, given the symptoms, very high (low). The disease has (no) serious consequences for the patient.

The medical treatment of this disease, an operation, has a $90 \%(30 \%)$ chance of success. There is hardly any risk for the patient. (The patient runs the risk of dying during the operation).

A very good friend of yours was recently admitted to a hospital for the operation in question. The operation succeeded (failed) and your friend is in perfect good health (died during the operation).

All of a sudden vou realise that you happen to have the three symptoms too.

\section{Dependent variables}

The dependent variables are worry about the disease and the intention to consult the GP. The same questions as in study 1 were submitted to the students. As in study 1 , an extra question was added, to get insight in the reasons of subjects' decisions to consult the GP or not. Besides the four alternatives already mentioned in study 1, we added the following ones

1. I do not intend to consult the GP because I have doubts about the medical treatment.

2. I intend to consult the GP but I have my doubts about the medical treatment for this disease.

3. I decide to consult the GP but I will refuse the medical treatment. 


\section{RESULTS AND DISCUSSION SCENARIO STUDY 2}

\section{Manipulation check}

Only the manipulation of susceptibility to the disease was checked. Subjects were asked to estimate (in percentages) the susceptibility to the disease, given that one has the symptoms. The mean score of the 'high susceptibility' condition (66.7\%) was significantly higher than the mean score of the 'low susceptibility' condition $(28,7 \%)(T=$ 10.25, $P<0.0011$.

The manipulations of severity, the objective information were not checked, because we would have been asking subjects to replicate information from the stories literally.

\section{Analysis}

A multivariate analysis of variance was performed using the answers to the 'worry' and the 'intention' questions as dependent variables and the four possible determinants as independent variables. The analysis showed that there was a significant main effect for severity $(F(2.143)=7.47, P<0.001)$. Level of severity significantly affected worry $(F(1,144)=14.98, P<0.001)$ and the intention to consult the $\operatorname{GP}(F(1,144)=7.17$. $P<0.01$ ). If subjects were told that the disease had serious consequences, subjects were significantly more worried and more inclined to consult the GP than subjects who were told that the disease had no serious consequences (for means, see Table 2).

These results are in line with the expectations based on the observational study and study 1 . There is no significant main effect for the variable susceptibility $(F(2,114)=$ 2.14, $P<0.12$ ), however, a finding not in line with study 1.

There is a significant main effect for the coincidental information about the medical treatment $(F(2,143)=6.53, P<0.01)$. The level of this information significantly affected worry about the disease $(F(1.144)=12.65, P<0.001)$, but not the intention to consult the GP. Whenever the operation of the friend is successful, the subjects are less worried than when the operation is fatal.

There is a significant main effect for objective information $(F(2,143)=3.56, P<$ 0.03 ), but the univariate tests surprisingly show that objective information does not significantly affect worry and intention to consult the GP. The analysis revealed no significant interaction effects.

Table 2. Mean scores of the significant determinants of worry and intention to consult the GP $(n=160)$

\begin{tabular}{|c|c|c|c|}
\hline & & Worry $^{a}$ & Intention ${ }^{\mathbf{a}}$ \\
\hline \multirow[t]{2}{*}{ Severity } & Low & 4.06 & 4.45 \\
\hline & High & 4.99 & 5.09 \\
\hline \multirow[t]{2}{*}{ Statistical chance treatment } & Low & 4.96 & 4.99 \\
\hline & High & 4.09 & 4.55 \\
\hline \multirow[t]{2}{*}{ Subjective chance treatment } & Low & 4.63 & 4.61 \\
\hline & High & 4.42 & 4.93 \\
\hline
\end{tabular}


The results of study 2 provide more support for a causal role for perceived severity of a disease in worry and intention to consult the GP. No influence of susceptibility on worry and intention to consult the GP was found, however, a result not consistent with the resuits of study 1 . It might be that the effect of susceptibility is 'overruled' by the effect of 'coin-cidental information'. Once patients hear about a friend having the same symptoms, they think they are susceptible themselves too; the objective susceptibility becomes irrelevant.

The reader will recall that, when predicting the effect of extreme worry on intention to consult the GP, we were not sure about the effect that could be expected: whether higher worry would always lead to greater intention to consult the GP, or if extreme worry would lead for example to denial, and to lower intention. Testing showed a linear trend $(F(6,153)=21.91, P<.001), T=8.79, P<0.001)$ and a quadratic trend $(P<$ $0.001, T=2.63, P<0.011$.

As the trend analysis suggests, the relation between worry and intention to consult the GP is linear (at least at the levels of worry reached here): that is the higher worry, the higher the intention to consult the GP. The quadratic trend refers to a 'dip' in the linear trend. In a situation where people cannot say if they are worried or not they are somewhat less inclined to consult the GP than one would expect on the basis of a linear relationship. In the condition (High susceptibility, high severity, 30\% success and the friend died) where the highest level of reported worry (6.2) was reached, the highest inclination to consult the GP (5.7) was found as well.

Although the relation between worry and intention to consult the GP indeed may be linear, some alternative explanations exist for not finding the trend that extreme anxiety will lead to a weaker intention to consult the GP. One explanation may be found in the answers subjects gave to the question to choose between eight alternatives concerning the decision to consult the GP in that particular situation. The answers showed that the students would consult their GP for more information ( $37 \%$ chose this option), despite their doubts about the operation. Subjects seem to reason that they can always ask for more information, and, in case of doubt, refuse the operation.

Another explanation focuses on subjects' understanding the meaning of the concept of chance. In the theoretical and empirical literature on risk perception, it is often concluded that patients have only a restricted comprehension of the concept of risk or chance (Kahneman \& Tversky, 1979; Slovic et al., 1982). They perceive the difference between 'chance' and 'certainty' but do not distinguish between a big chance and a moderate one. In other words, the psychological distance between a chance of $50 \%$ and $75 \%$ is smaller than the psychological chance between $0 \%$ and $25 \%$. Thus, patients might not consider a success rate of $10 \%$ as low as it really is; they only conclude that they have a chance of surviving.

\section{GENERAL DISCUSSION}

In summary, we may conclude from the first study that the perceived efficacy of self care, perceived severity of the disease and perceived susceptibility to a disease seem to play a causal role in the decision to consult the GP. An unexpected finding was that efficacy of GP care seemed to have no effect on the decision to consult the GP, a result for which we found strong evidence in the observational study. This finding, however, may be an artifact of the experimental situation: the unknown disease may have caused a greater need for information. 
In both studies the perceived susceptibility and severity determined worry about the complaint or disease (cf. 'Health Belief Model', Janz \& Becker, 1984; Mullen et al., 1987). Perceived efficacy of GP care and self care did not determine worry.

The results of the second study provide more support for a causal role of perceived severity of the disease in worry and intention to consult the GP. However, no influence of susceptibility on worry and intention to consult the GP was found. The effect of susceptibility and statistical information might be 'overruled' by the effect of 'coincidental information'. Information about a friend having the same symptoms and treatment could lead to the idea that objective information about susceptibility and treatment is irrelevant. It must be noted that though we found evidence in the two studies that the intention to consult the GP was affected by variations in perceptions of complaint and perceptions of care, we may not conclude that the (intention to) consult the GP may never cause changes in perceptions. The scenario studies were designed only to determine if perceptions at least have causal influence on intention to consult the GP; no scenario studies were executed to track if there is also a causal relationship the other way around.

We freely compared the results of the observational study with the results of the scenario studies, although it is obvious that such a comparison is limited by some differences between these studies. Firstly, subjects in the observational study were answering questions about a real event, while subjects in the study reported here had to imagine the situation.

Secondly, a related point, the consultation behaviour of subjects in the observational study was real, whereas in the scenario studies subjects reported their intention to consult the GP. We feel justified, however, in comparing the results of the studies, albeit in a tentative way, on two grounds. The first is that findings of the scenario studies, often replicate the findings of 'real life' situation studies (cf. Bem, 1965; Bem, 1967). The second is that the correlations reported between behavioural intentions and actual behaviour generally are high, especially if subjects are motivated enough, and if subjects are capable of executing their intentions (Becker \& Maiman, 1975). Motivation in this case may be expected to be high, and since going to the GP in the Netherlands is not a behaviour that is difficult to execute successfully, we think intention to consult the GP and actual consulting will be highly related.

Results show that in general the scenario studies yield the same results as the observational study conducted earlier. Observational studies and experimental studies may be seen as useful complementary methods. Comparing results in the real world and in an artificial situation also showed some discrepancies however. Thus, although experimental and observational studies may be complementary methods, experimental research should not substitute for observational studies. Because most findings do match, experimental studies may be useful in exploring relatively unknown fields. In conclusion, inasmuch as this study may contribute to GPs not being consulted unnecessarily by patients, perhaps it may also contribute to patients not being consulted unnecessarily by researchers (although in both cases unnecessary delay can give rise to problems). 


\section{REFERENCES}

Becker, M.H., \& Maiman, L.A. (1975). Sociobehavioral determinants of compliance with health and medical care recommendations. Medical Care, 13, 10-24.

Becker, M.H., Haefner, D.P., KasI, S.V., Kirscht, J.P., Maiman, L.A., \& Rosenstock, I.M. (1977). Selected psychosocial models and correlates of individual health-related behaviors. Medical Care, 15 (Supplement), 27-46.

Bem, D.J. (1965). An experimental analysis of self-persuasions. Journal of Experimental Social Psychology, 1, 199-218.

Bem, D.J. (1967). Self-perception: An alternative interpretation of cognitive dissonance phenomena. Psychological Review, 74, 183-200.

Berkanovic, E., Telesky, C., \& Reeder, S. (1981). Structural and social psychological factors in the decision to seek medical care for symptoms. Medical Care, 19, 693-709.

Berwick, D.M., Budman, S., Damico-White, J., Feldstein, M., \& Klerman, G.L. (1987). Assessment of psychological morbidity in primary care: Explorations with the general health questionnaire. Journal of Chronic Diseases, 40 (Supplement), 71-84.

Donohew, L., Sypher, H., \& Higgins, E. (Eds.) (1988). Communication, Social Cognition, and Affect. Lawrence Erlbaum Associates, Hillsdale N.J..

Grimsmo, A., \& Siem, H. (1984). Factors affecting primary health care utilization, Family Practice, 1, 155-161.

Janz, N.K., \& Becker, M.H. (1984). The Health Belief Model: A decade later. Health Education Quarterly, 11, 1-47.

Kahneman, D., \& Tversky, A. (1979). Prospect theory, an analysis of decision under risk. Econometrica, 47, 263-291.

Kar, van de, A.G.A., Knottnerus, J.A., Meertens, R.M., Dubois, V., \& Kok, G.J. (1992a). Why do patients consult the general practitioner? Determinants of their decision. British Journal of General Practice, 42, 313-316.

Kar, van de, A.G.A., Grinten, van der, R.F., Meertens, R.M., Kok, G.J., \& Knottnerus, J.A. (1992b). Worry: A particular determinant of consultation illuminated. Family Practice, 9, 67-75.

Leavitt, F. (1979). The Health Belief Model and utilization of ambulatory care services. Social Science and Medicine, 13A, 105-112.

Leventhal, H. (1970). Findings and theory in the study of fear communications. In Berkowitz, L. (Ed.), Advances in Experimental Social Psychology. Vol. 5. Academic Press, New York, p. 119-186.

Like, R., \& Zyzanski, S.J. (1986). Patient requests in family practice: A focal point for clinical negotiations. Family Practice, 3, 216-228.

McKinlay, J.B. (1972). Some approaches and problems in the study of the use of services - An overview. Journal of Health and Social Behavior, 13, 115-152.

Meininger, J.C. (1986). Sex differences in factors associated with use of medical care and alternative illness behaviors. Social Science and Medicine, 22, 285-292.

Mullen. P.D., Hersey, J.C., \& Iverson, D.C. (1987). Health behavior models compared. Social Science and Medicine, 24, 973-981.

Nisbett, R.E., \& Ross, L. (1980). Human Inference: Strategies and shortcomings of social judgment. Prentice Hall, Englewood Cliffs NJ.

Schramm, W., \& Roberts, D.F. (Eds.) (1977). The Process and Effects of Mass Communication (revised edition) University of Illinois Press, Chicago.

Schrire, S. (1986). Frequent attenders - A review. Family Practice, 3, 272-275. 
Siero, S., Kok, G.J., \& Pruyn, J. (1984). Effects of public education about breast cancer and breast self-examination. Social Science and Medicine, 18, 881-888.

Slovic, P., Fischhoff, B., \& Lichtenstein, S. (1982). Facts versus fears: Understanding perceived risk. In Kahneman, D., Slovic, P., \& Tversky, A. (Eds.), Judgment under uncertainty, Heuristics and biases. Cambridge University Press, Cambridge, p. 463-489.

Sutton, S.R. (1982). Fear arousing communications: A critical examination of theory and research. In Eiser, J. (Ed.), Social Psychology and Behavioral Medicine. Wiley, Chicester, p. 303-337.

Tversky, A., \& Kahneman, D. (1974). Judgment under uncertainty: Heuristics and biases. Science, 185, 1124-1131.

Westhead, J. (1985). Frequent attenders in general practice: Medical, psychological and social characteristics. The Journal of the Royal College of General Practitioners, 35, 337-340. 


\section{SUMMARY}

This thesis focuses on the determinants of consulting the general practitioner (GP) about one complaint, but not about another complaint. In the research reported here the impact of several factors on the decision to consult the GP is considered. Special attention is paid to the determinant 'worry', therefore, the factors that determine the worry patients experience are investigated as well. In addition we try to gain some insight into how worry and other determinants are influenced by consulting the GP.

Chapter one gives an overview of the whole thesis. The chapter contains an introduction to the studies reported, and describe their theoretical background. Furthermore it summarizes the studies executed, their major shortcomings, and formulates the most important conclusions for theory, practice and methods that can be drawn from the research done.

The theoretical basis for the studies reported is the 'Health Belief Model' (HBM). The HBM was originally formulated to explain (preventive) health behaviour. The HBM assumes that the subjective health considerations (like the perceived susceptibility to a disease or perceived severity of the complaint) determine whether people undertake a health related action, like consulting the GP. Though the HBM has proven itself in explaining a wide range of health behaviours, we made some extra additions (perceived efficacy of self care and need for information) and slight changes to the model.

Research into backgrounds of people's decision to consult the GP is needed if effective use of the medical services provided by the GP is to be promoted. Effective use means, on the one hand, no unnecessary consulting (which leads to medicalization, wasted GP time and extra costs) and, on the other hand, no unnecessary delay (which might lead to prolongation of the disease and more complex treatment).

The research questions are formulated from the point of view of a health educator: the study into the determinants of GP consultation is seen as a necessary stage in developing an intervention aimed at promoting effective use of GP services; and in a way the GP-patient interaction is approached as a small health education intervention, which may be expected to have an effect on determinants of consulting the GP.

In chapter two we find a study which gives more information about the reasons for consulting the GP. Patients, consulting the GP, answered questions about the complaint for which they consulted their GP. Questions were based on the HBM, augmented by two additional factors: the perceptions patients have of their own possibilities to cope with the complaint, and their need for information. Then, patients were asked whether they had another complaint, they did not (intend to) consult the GP about. If they had such a complaint, they were asked to fill in the same questions as for the complaint for which they did consult the GP. Furthermore, background characteristics were covered by the questionnaire.

To gain insight in the determinants of GP consultation perceptions regarding complaints for which the GP was consulted were compared with perceptions regarding complaints for which the GP was not consulted. Multiple logistic regression analysis revealed that perceptions concerning the effectiveness of self care, the efficacy of GP care and the perceptions of the complaint explained an important part of the decision to consult the GP. When patients feel that the complaint can be treated without the help of the GP or the complaint is not serious, or the GP can give no effective help, they are less likely to consult the GP. The perceived need for information also is an important reason for patients to consult the GP. 
In chapter three we explore the worry experienced by patients in the GP waiting room and the reasons for being worried. 791 patients completed a structured questionnaire just before they consulted their GP and afterwards. Worry was operationalized as a combination of anxiety and uncertainty about health.

Results indicate that worry was related to the perceptions of patients concerning the complaint and the need for more information about the complaint. Perceptions concerning the complaint could explain worn better than, for instance, personal characteristics like age or sex of the patients. General health status and frequency of consultations per year were related to the general worry patients experience. According to the patients' self reports, worry was almost never due to information from the mass media or from other persons, or to a concern for the consultation itself.

Furthermore, results show that the worry patients experience decreases from before to after consultation. This decrease of worry, however, is larger for patients who are very positive about the consultation than patients who are less positive. Consulting the GP seems to have a reassuring effect on the patients, especially when the GP discusses the worry appropriately in the patient's view.

In chapter four we describe patients' health beliefs about the complaint, their beliefs about the efficacy of GP care and self care and their level of and need for information before consulting the GP. The study reported in this chapter furthermore determines whether patients change their health beliefs after consulting the GP. The results show that a consultation leads to significant changes in the beliefs about the complaint, the level of information one has and the care the GP can provide. After consultation, patients think that their complaint is less serious and the chance that they suffer from a serious disease is smaller than before consultation. Patients' need for more information seems to have decreased after consulting the GP. However patients still feel that they have not enough information. Patients perceive GP care as less effective after, than before consultation. However, this effect seems to be qualified by the extent to which patients feel satisfied with the GP consultation. The perception very satisfied patients have of the efficacy of GP care remains the same before and after consultation. Less satisfied patients, however, perceived GP care as less effective after consultation. Improving the provision of information both by the GP and by the patient may partly solve the problems of relative dissatisfaction with health care some patients experience.

The observational studies reported in chapter two, three and four have the advantage of being conducted in a 'real life' situation. A disadvantage, however, is that it is difficult to determine causal relations, a disadvantage which is especially important if the intention is to influence the decision to consult the GP in a (health education) intervention by influencing health beliefs. Therefore, it was decided to conduct two 'scenario studies', paper en pencil experiments allowing cause-effect relations to be tested. These scenario studies are reported in chapter five

The two scenario studies were presented to 160 Health Science students. In the first scenario study we presented a story describing a person reading an article about a certain disease in the morning paper. Four possible determinants of consulting the GP were systematically varied between stories: the susceptibility of the person to the disease, the severity of the disease, the benefit which could be expected from GP care and possibilities of self care. We asked subjects to imagine themselves in the position of the person in the story, and to indicate how worried they would feel and how strong their inclination would be to see their GP.

In the second scenario study, besides evaluating the influence of susceptibility and severity, we tested whether coincidental information (about a friend who happened to 
have the disease, and in whom the medical treatment did or did not succeed) influenced worry and intention to consult the GP.

Results show that in general the scenario studies yield the same results as the observational study conducted earlier. On basis of these scenario studies it now, for example, can be concluded that low perceived efficacy of self care seems to cause high intention to consult the GP. However, some discrepancies in results were found as well. In the scenario studies we found that coincidental information had a strong influence on worry and the intention to consult the GP, a result not found in real life. This finding, however, may be an artifact of the experimental situation. We conclude that experimental and observational studies are complementary methods, and that scenario studies may be an efficient and an economical method to explore a relatively new research area.

The research reported in this thesis has enabled the following theoretical, practical and methodological conclusions to be drawn. Firstly, the HBM is a useful model to explain GP consultation behaviour, though the elaboration of the HBM with two factors (efficacy of self care and need for information) might be considered. Secondly, though a GP consultation in general seems to have a positive effect on health beliefs (for example worry) and leads to less need for knowledge, patients still feel they do not have enough information when they leave the GP. Both the patient and the GP might profit from more structured exchange of information. Thirdly, with respect to the methodology, we conclude that observational and experimental studies may sometimes be used as complementary methods; observational studies give information about relations in real life settings, scenario studies may give causal information about the same relations in a somewhat artificial situation. Furthermore, scenario studies may be recommended to explore relatively new research areas. 


\section{SAMENVATTING}

Dit proefschrift geeft een beschrijving van een onderzoek naar de determinanten van huisartsbezoek. Met andere woorden, onderzocht werd waarom mensen hun huisarts raadplegen voor de ene klacht, maar niet voor de andere klacht. De rol van verschillende determinanten van huisartsbezoek werd onder de loep genomen: bijvoorbeeld de perceptie van mensen met betrekking tot de ernst van de klacht, de behoefte aan informatie over de klacht en het advies dat mensen krijgen van anderen. In het onderzoek werd speciale aandacht besteed aan de determinant 'ongerustheid': enerzijds omdat het een belangrijke reden is om de huisarts te raadplegen, anderzijds omdat ongerustheid een groeiend probleem in de arts-patiënt interactie vormt. Daarnaast hebben we getracht inzicht te krijgen in hoe ongerustheid en andere determinanten beinvloed worden door het huisartsbezoek.

Hoofdstuk een geeft een overzicht van het gehele proefschrift. Het hoofdstuk introduceert de beschreven onderzoeken en beschrijft de theoretische achtergrond. Verder worden de uitgevoerde onderzoeken kort samengevat waarbij ook de belangrijkste resultaten aan bod komen. Tenslotte worden de belangrijkste conclusies beschreven, uitgesplitst naar conclusies voor de theorie, voor de praktijk en voor de gehanteerde onderzoeksmethoden.

De theoretische basis voor de beschreven onderzoeken wordt gevormd door het Health Belief Model (HBM). Het HBM, van oorsprong ontwikkeld om (preventief) gezondheidsgedrag te verklaren, gaat uit van de veronderstelling dat subjectieve gezondheidsoverwegingen bepalen of mensen bepaalde gezondheidsacties, zoals het raadplegen van de huisarts, zullen ondernemen. Bijvoorbeeld, het HBM gaat ervan uit dat de perceptie van de ernst van de klacht de stuwende kracht is achter een gezondheidsactie, en niet de werkelijke ernst. Ondanks het feit dat onderzoek laat zien dat een groot aantal gezondheidsgedragingen op deze wijze redelijk goed verklaard kunnen worden, heeft een kritische beschouwing van het model in dit onderzoek geleid tot enkele aanvullingen en aanpassingen.

Onderzoek naar de achtergronden van de beslissing om de huisarts te raadplegen is nodig als men een effectief gebruik van medische hulpverlening door de huisarts wil bevorderen. Effectief gebruik betekent enerzijds geen onnodig huisartsbezoek (dat kan leiden tot medicalisering, extra tijdsbelasting van de huisarts en kosten); anderzijds geen onnodig uitstel van huisartsbezoek (dat kan leiden tot een meer complexe ziektegeschiedenis en een meer ingrijpende behandeling).

In hoofdstuk twee vinden we meer informatie over het onderzoek naar de determinanten van huisartsbezoek. In de wachtkamer van de huisarts vulden 1000 patiënten een vragenlijst in voordat ze door de huisarts geroepen werden. De vragenlijst is gebaseerd op het HBM, aangevuld met twee factoren: de percepties van patienten ten aanzien van hun eigen mogelijkheden om de klacht te verhelpen en hun behoefte aan meer informatie over de klacht.

Na het consult werd aan deze patiënten gevraagd of zij nog een andere klacht hadden, waarvoor ze niet naar de huisarts waren gegaan en ook niet van plan waren te gaan. Als ze zo'n klacht hadden, kregen de patiënten nogmaals de vragen voorgelegd die ze al beantwoord hadden voor de klacht waarvoor ze wel naar de huisarts waren gegaan Ook werden in deze vragenlijst de achtergrondgegevens van de patiënten verzameld, zoals demografische gegevens.

Om verklaringen te vinden voor de beslissing om wel of niet de huisarts te raadplegen voor een klacht, werden de gezondheidsopvattingen voor de klacht waarvoor de 
huisarts wel en niet geraadpleegd was, vergeleken. Multiple logistische regressie analyses gaven aan dat percepties met betrekking tot de klacht, de effectiviteit van het huisartsbezoek, de eigen mogelijkheden om een klacht te verhelpen en de behoefte aan informatie, een belangrijk gedeelte van de variantie verklaarden van de beslissing om de huisarts te raadplegen. Als patiënten van mening zijn dat ze de klacht kunnen verhelpen zonder de hulp van de huisarts, de klacht niet ernstig vinden of denken dat de huisarts de klacht niet kan verhelpen, zullen ze minder snel geneigd zijn de huisarts te raadplegen. Tegen de verwachtingen in verklaarde de kans die men dacht te hebben op een ernstige ziekte nauwelijks de keuze om voor een klacht de huisarts wel of niet te raadplegen.

In hoofdstuk drie wordt getracht de ongerustheid van de persoon, die in de wachtkamer van de huisarts zit, en de redenen voor deze ongerustheid nader te onderzoeken. 791 patiënten vulden de vragenlijst in vóór en ná het consult. Ongerustheid werd geoperationaliseerd als een combinatie van onzekerheid en angst.

De resultaten toonden aan dat de ongerustheid met name werd veroorzaakt door de percepties ten aanzien van de klacht (zoals de waargenomen ernst van de klacht) en de behoefte aan informatie over de klacht. Deze percepties waren meer bepalend voor de mate van ongerustheid dan demografische kenmerken van de patiënt, zoals de leeftijd of het geslacht van de patiënt. Wel waren de algemene gezondheidsstatus en het aantal huisartsbezoeken per jaar van invloed op de algemene ongerustheid die patiënten ervaren. De respondenten gaven zelf aan dat ongerustheid niet bepaald wordt door massamediale informatie of door andere personen, of door 'drempelvrees', de ongerustheid ten aanzien van het huisartsbezoek zelf.

Verder gaven de resultaten aan dat het huisartsbezoek een positieve werking had op de ongerustheid van de patiënten. Deze afname van ongerustheid bleek echter groter te zijn bij de erg tevreden dan bij de wat minder tevreden patiënten. Het huisartsbezoek had een geruststellend effect op de patiënten, in het bijzonder als de huisarts de klacht en de bijbehorende ongerustheid naar tevredenheid van de patiënt besprak.

In hoofdstuk vier worden de gezondheidsopvattingen van de patiënten ten aanzien van de klacht, de zorg en de informatie vóór het consult beschreven. Daarnaast wordt er op ingegaan of het gesprek tussen huisarts en patiënt veranderingen teweeg heeft gebracht bij de patiënt wat betreft deze gezondheidsopvattingen. De resultaten laten zien dat inderdaad na het consult significante veranderingen zijn opgetreden in de percepties over de klacht, de mogelijkheden van zorg door de huisarts en de informatiebehoefte. Na het consult dachten patiënten dat hun klacht minder ernstig was en dat de kans op een ernstige ziekte kleiner was dan vóór het consult. De behoefte van de patiënten aan meer informatie over de klacht bleek kleiner te zijn ná het huisartsbezoek, hoewel de patiënten nog steeds aangaven niet voldoende informatie over de klacht te hebben. De perceptie met betrekking tot de effectiviteit van de zorg door de huisarts werd na het consult lager ingeschat. Dit effect bleek echter alleen op te treden bij patiënten die relatief ontevreden waren over het consult, de patiënten die zeer tevreden waren in dit opzicht achtten de effectiviteit van de zorg door de huisarts voor en na het consult even groot.

De veldstudies, beschreven in hoofdstuk twee, drie en vier, hadden als voordeel dat deze plaatsvonden in de alledaagse werkelijkheid. Deze opzet had echter als nadeel dat op deze manier geen causale verbanden vastgesteld konden worden. Dit nadeel weegt bijzonder zwaar als men van plan is de beslissing om de huisarts te raadplegen te beïnvloeden door een (voorlichtings) interventie gericht op de gezondheidsopvattingen. Daarom werd besloten twee zogenaamde 'scenario studies' vit te voeren, die ons in staat stelden wel oorzaak-gevolg verbanden te leggen. Deze scenario studies worden beschreven in hoofdstuk vijf. 
De twee scenario studies werden uitgevoerd met 160 studenten Gezondheidswetenschappen als proefpersonen. In de eerste scenario studie werd een casus aan de studenten voorgelegd waarin een persoon een kranteartikel leest over een bepaalde ziekte. In deze casus werden vier mogelijke determinanten van huisartsbezoek systematisch gevarieerd: de kans op de ziekte, de ernst van de ziekte, de effectiviteit van de huisarts en de mogelijkheid om zelf de klachten op te lossen. De studenten werd gevraagd zich zo goed mogelijk te verplaatsen in de rol van de persoon uit de casus en aan te geven in welke mate ze zich nu ongerust voelden en hoe groot hun intentie zou zijn om de huisarts te raadplegen.

In de tweede scenario werd, naast de invloed van de kans op de ziekte en de ernst van de ziekte, gemeten in welke mate de ongerustheid en de intentie om de huisarts te raadplegen beînvloeden werd door statistische informatie over de kans van slagen van de behandeling (door informatie te geven over de kans van slagen in procenten), en subjectieve informatie over de kans van slagen van de behandeling (door informatie te geven over een vriend die deze ziekte toevallig ook had en waarbij de behandeling wel of niet geholpen had).

De resultaten komen in vrij grote mate overeen met de resultaten van het onderzoek in de wachtkamer van de huisarts. Op basis van de scenario studies kan geconcludeerd worden dat een lage perceptie van de eigen mogelijkheden om de klacht te verhelpen mensen er inderdaad toe lijkt aan te zetten de huisarts te raadplegen. Er waren echter ook een aantal discrepanties tussen het onderzoek in de wachtkamer en de scenario studies, zoals het effect van de factor 'iemand kennen met dezelfde klacht'. Deze determinant, die uit de scenario studie als een belangrijke factor naar voren kwam, bleek in de alledaagse praktijk geen rol van betekenis te spelen. Deze discrepantie kan mogelijk verklaard worden doordat mensen in het onderzoek in de wachtkamer zeiden niemand te kennen met een vergelijkbare klacht. In grote lijnen bleken de scenario studies echter een goede aanvulling te zijn op het onderzoek in de wachtkamers van de huisartsen.

Het onderzoek zoals beschreven in dit proefschrift heeft geleid tot conclusies voor de theorie, de praktijk en de onderzoeksmethoden. Allereerst is het HBM een nuttig model om het huisartsbezoek te verklaren, waarbij wel aangetekend dient te worden dat het toevoegen van twee determinanten zelfzorg en de behoefte aan informatie overwogen dient te worden.

Ten tweede, alhoewel het huisartsbezoek in het algemeen een positief effect heeft op de gezondheidsopvattingen (bijvoorbeeld ongerustheid) en leidt tot minder behoefte aan kennis, geven patiēnten nog steeds aan niet genoeg informatie te hebben ná het huisartsbezoek. Zowel de patiënt als de huisarts zouden hun voordeel kunnen halen uit een meer gestructureerde uitwisseling van informatie.

Ten derde, met betrekking tot de methoden van onderzoek, kunnen we concluderen dat veldstudies en scenario studies in sommige situaties als complementaire methoden toegepast kunnen worden; de veldstudie geeft informatie over verbanden die in de werkelijkheid bestaan, de scenario studies geven causale informatie over causale relaties in een soms wat kunstmatige situatie. De scenario studies kunnen de belasting van patiënten en huisartsen door wetenschappelijk onderzoek behoorlijk verminderen en kunnen een goede en efficiënte methode zijn om enig inzicht te verkrijgen in een relatief nieuw veld. 


\section{ANNEX 1 REFERENCES}

Ajzen, I., \& Fishbein, M. (1980). Understanding attitudes and predicting social behavior. Englewood Cliffs: Prentice Hall.

Bain, D.J.G. (1977). Patient knowledge and the content of the consultation in general practice. Medical Education, 11, 347-350.

Becker, M.H. (Ed.). (1974). The Health Belief Model and personal health behavior [Special issue]. Health Education Monographs, 2, 326-473.

Becker, M.H., Haefner, D.P., Kasl, S.V., Kirscht, J.P., Maiman, L.A., \& Rosenstock, I.M. (1977). Selected psychosocial models and correlates of individual health-related behaviors. Medical Care, 15 (Supplement), 27-46.

Becker, M.H., \& Maiman, L.A. (1975). Sociobehavioral determinants of compliance with health and medical care recommendations. Medical Care, 13, 10-24.

Bem, D.J. (1965). An experimental analysis of self-persuasions. Journal of Experimental Social Psychology, 1, 199-218.

Bem, D.J. (1967). Self-perception: An alternative interpretation of cognitive dissonance phenomena. Psychological Review, 74, 183-200.

Ben-Sira, Z. (1976). The function of the professional's affective behavior in client satisfaction: A revised approach to social interaction theory. Journal of Health and Social Behavior, 17, 3-11.

Berkanovic, E., Telesky, C., \& Reeder, S. (1981). Structural and social psychological factors in the decision to seek medical care for symptoms. Medical Care, 19,693-709.

Berwick, D.M., Budman, S., Damico-White, J., Feldstein, M., \& Klerman, G. L. (1987). Assessment of psychological morbidity in primary care: Explorations with the general health questionnaire. Journal of Chronic Diseases, 40 (Supplement), 71-84.

Boreham, P., \& Gibson, D. (1978). The informative process in private medical consultations: A preliminary investigation. Social Science and Medicine, 12, 409-416.

Boulton, M.G., Griffiths, J., Hall, D., Mcintyre, M., Oliver, B., \& Woodward, J. (1984). Improving communication: A practical programme for teaching trainees about communication issues in the general practice consultation. Medical Education, 18, 269-274.

Branch, L.G., \& Nemeth, K.T. (1985). When elders fail to visit physicians. Medical Care, 23, 1265-1275.

Buchsbaum, D.G. (1986). Reassurance reconsidered. Social Science and Medicine, 23, 423 427.

Calnan, M. (1984). The Health Belief Model and participation in programmes for the early detection of breast cancer: A comparative analysis. Social Science and Medicine, 19, 823-830.

Carter, W.B., Inui, T.S., Kukull, W.A., \& Haigh, V.H. (1982). Outcome-based doctor-patient interaction analysis: II. Identifying effective provider and patient behavior. Medical Care, 20, 550-566.

Cassee, E. (1973). Naar de dokter. Enkele achtergronden van ziektegedrag en gezondheidszorg. Dissertatie. Meppel: Boom.

Cockburn, J., Fahey, P., \& Sanson-Fisher, R.W. (1987). Construction and validation of a questionnaire to measure the health beliefs of general practice patients. Family Practice, 4, 108-116.

Comstock, L.M., Hooper, E.M., Goodwin, J.M., \& Goodwin, J.S. (1982). Physician behaviors that correlate with patient satisfaction. Journal of Medical Education, 57. 105-112.

Cox, C. (1986). Physician utilization by three groups of ethnic elderly. Medical Care, 24, 667-676. 
Cummings, K.M., Becker, M.H. , \& Maile, M.C. (1980). Bringing the models together: An empirical approach to combining variables used to explain health actions. Journal of Behavioral Medicine, 3, 123-145.

DiMatteo, M.R., \& DiNicola, D.D. (1982). Achieving patient compliance. The psychology of the medical practitioner's role. New York: Pergamon Press.

Donohew, L., Sypher, H., \& Higgins, E. (Eds.). (1988). Communication, Social Cognition, and Affect. Hillsdale N.J.: Lawrence Erlbaum Associates.

Fletcher, C. (1979). Towards better practice and teaching of communication between doctors and patients. In G. McLachlan G (Ed.), Essays on Current Research. Twelfth Series, Nuffield Provincial Hospitals Trust: Mixed Communications Problems and Progress in Medical Care (pp. 3-41). Oxford: University Press.

Grimsmo, A., \& Siem, H. (1984). Factors affecting primary health care utilization. Family Practice, 1, 155-161.

Grinten, R., van der. (1988). Inbreng van patienten. Een onderzoek van spreekuurkontakten. Dissertatie. Nijmegen: Katholieke Universiteit Nijmegen.

Hannay, D.R. (1979). The symptom iceberg. London: Routledge \& Kegan Paul.

Harrison, J.A., Mullen, P.D., \& Green, L.W. (1992). A meta-analysis of studies of the Health Belief Model. Health Education Research, Theory \& Practice, 7, 107-116.

Helman, C.G. (1985). Communication in primary care: The role of patient and practitioner explanatory models. Social Science and Medicine, 20, 923-931.

Hibbard, J.H., \& Pope, C.R. (1986). Age differences in the use of medical care in an HMO. An application of the behavioral model. Medical Care, 24, 52-66.

Hochbaum, G.M. (1983, November). The Health Belief Model revisited. Paper presented at the Annual Meetings of the American Public Health Association, Dallas, Texas.

Hofmans-Okkes, 1. (1991). Op het spreekuur. Oordelen van patienten over huisartsconsulten.

Dissertatie. Lelystad: Universiteit van Amsterdam.

Janz, N.K., \& Becker, M.H. (1984). The Health Belief Model: A decade later. Health Education Quarterly, 11, 1-47.

John, C., Schwenk, T.L., Roi, L.D., \& Cohen, M. (1987). Medical care and demographic characteristics of 'difficult' patients. The Journal of Family Practice, 24, 607-610.

Jones, R.A., Wiese, H.J., Moore, R.W., \& Haley, J.V. (1981). On the perceived meaning of symptoms. Medical Care, 19, 710-717.

Jones, R. (1987). Self-care and primary care of dyspepsia: A review. Family Practice, 4, 68-77.

Jongh, T., de (1987). Ongerustheid, een eerstelijnsziekte. Medisch Contact, 42, 828-830.

Kahneman, D., \& Tversky, A. (1979). Prospect theory, an analysis of decision under risk. Econometrica, 47, 263-291.

Kar, A.G.A., van de, Knottnerus, J.A., Meertens, R.M., Dubois, V., \& Kok, G.J. (1992a). Why do patients consult the general practitioner? Determinants of their decision. British Journal of General Practice, 42, 313-316

Kar, A.G.A., van de, Grinten, R.F., van der, Meertens, R.M., Kok, G.J., \& Knottnerus, J.A. (1992b). Worry: A particular determinant of consultation illuminated. Family Practice, 9, 67-75.

Kar, A.G.A., van de, Kok, G.J., Meertens, R.M., \& Knottnerus, J.A. (submitted). Changes in patients' health beliefs after consulting the general practitioner. British Journal of General Practice.

Kar, A.G.A., van de, Meertens, R.M., Kok, G.J., \& Knottnerus, J.A. (submitted). Determinants of consulting the general practitioner and patients' worry. An experimental and an observational study compared. Health Education Research: Theory \& Practice.

Kirscht, J.P. (1983). Preventive health behavior: A review of research and issues. Health Psychology, 2, 277-301. 
Krantz, D.S., Baum, A., \& Wideman, M., van. (1980). Assessment of preferences for self-treatment and information in health care. Journal of Personality and Social Psychology, 5 , 977-990.

Leavitt, F. (1979). The Health Belief Model and utilization of ambulatory care services. Social Science and Medicine, 13A, 105-112.

Leventhal, H. (1970). Findings and theory in the study of fear communications. In L. Berkowitz (Ed.), Advances in Experimental Social Psychology: Vol. 5. (pp. 119-186). New York: Academic Press.

Ley, P. (1976). Towards better doctor-patient communication. In A. Bennett (Ed.), Communications Between Doctors and Patients (pp. 77-98). London: Oxford University Press.

Ley, P. (1982a). Giving information to patients. In J. Eiser (Ed.), Social Psychology and Behavioral Medicine (pp. 339-373). Chicester: Wiley.

Ley, P. (1982b). Satisfaction, compliance and communication. British Journal of Clinical Psychology, 21, 241-254.

Like, R., \& Zyzanski, S.J. (1986). Patient requests in family practice: A focal point for clinical negotiations. Family Practice, 3, 216-228.

Lisdonk, E., van de. (1985). Ervaren en aangeboden morbiditeit in de huisartsenpraktijk. Dissertatie. Nijmegen: Katholieke Universiteit Nijmegen.

Lydeard, S., \& Jones, R. (1989). Factors affecting the decision to consult with dyspepsia: Comparison of consulters and non-consulters. Journal of the Royal College of General Practitioners, 39, 495-498.

Markides, K.S., Levin, J.S., \& Ray, L.A. (1985). Determinants of physician utilization among Mexican-Americans. A three-generation study. Medical Care, 23, 236-246.

McKinlay, J.B. (1972). Some approaches and problems in the study of the use of services - An overview. Journal of Health and Social Behavior, 13, 115-152.

Meininger, J.C. (1986). Sex differences in factors associated with use of medical care and alternative illness behaviors. Social Science and Medicine, 22, 285-292.

Mullen, P.D., Hersey, J.C., \& Iverson, D.C. (1987). Health behavior models compared. Social Science and Medicine, 24, 973-981.

Neven, J. (1980). Uitstelduur en praktijkvoering. Een onderzoek in een aantal huisartsenpraktijken. Dissertatie. Maastricht: Rijksuniversiteit Limburg.

Nisbett, R.E., \& Ross, L. (1980). Human Inference: Strategies and shortcomings of social judgment. Englewood Cliffs NJ: Prentice Hall.

Pendleton. D., \& Hasler, J. (Eds.). (1983). Doctor-Patient Communication. New York: Academic Press.

Prentice-Dun, S., \& Rogers, R.W. (1986). Protection Motivation Theory and preventive health: beyond the Health Belief Model. Health Education Research. Theory and Practice, 1. 153-161.

Rieff, T., \& Bremer, J. (1982). De rol van angst bij de medisch consumptie van astmapatiënten: De Denverse onderzoeken. De Psycholoog, 17, 721-727.

Rippetoe, P.A., \& Rogers, R.W. (1987). Effects of components of protection-motivation theory on adaptive and maladaptive coping with a health threat. Journal of Personality and Social Psychology, 52, 596-604.

Robinson, E.J., \& Whitfield, M.J. (1987). Participation of patients during general practice consultations: Comparison between trainees and experienced doctors. Family Practice, 4 , 5-10.

Rosenstock, I.M. (1974). The health belief model and preventive health behavior. Health Education Monographs, 2, 354-386.

Roter. D.L. (1977). Patient participation in the patient-provider interaction: The effects of patient question asking on the quality of interaction, satisfaction and compliance. Health Education Monographs, 5, 281-315. 
Schramm, W., \& Roberts, D.F. (Eds.). (1977). The Process and Effects of Mass Communication (revised edition). Chicago: University of Illinois Press.

Schrire, S. (1986). Frequent attenders - A review. Family Practice, 3, 272-275.

Siero, S., Kok, G.J., \& Pruyn, J. (1984). Effects of public education about breast cancer and breast self-examination. Social Science and Medicine, 18, 881-888.

Slovic, P., Fischhoff, B., \& Lichtenstein, S. (1982). Facts versus fears: Understanding perceived risk. In D. Kahneman, P. Slovic, \& A. Tversky (Eds.), Judgment under uncertainty, Heuristics and biases (pp. 463-489). Cambridge: Cambridge University Press.

Smith, C.K., Polis, E., \& Hadac, R.R. (1981). Characteristics of the initial medical interview associated with patient satisfaction and understanding. The Journal of Family Practice, 12 , 283-288.

Stewart, M.A., McWhinney, I.R., \& Buck, C.W. (1979). The doctor/patient relationship and its effect upon outcome. Journal of the Royal College of General Practitioners, 29, 77-81

Stimson, G., \& Webb, B. (1975). Going to see the doctor. The consultation process in general practice. London: Routledge \& Kegan Paul.

Strecher, V.J., McEvoy DeVellis, B., Becker, M.H., \& Rosenstock, I.M. (1986). The role of selfefficacy in achieving health behavior change. Health Education Quarterly, 13, 73-91.

Sutton, S.R. (1982). Fear arousing communications: A critical examination of theory and research. In J. Eiser (Ed.), Social Psychology and Behavioral Medicine (pp. 303-337). Chicester: Wiley.

Tanner, J.L., Cockerham, W.C., \& Spaeth, J.L. (1983). Predicting physician utilization. Medical Care, 21, 360-369.

Taylor, S.E. (1986). Health Psychology. New York: Random House.

Toemen, T., \& Grol, R. (1989). De huisarts geeft voorlichting: reacties van patiënten na het

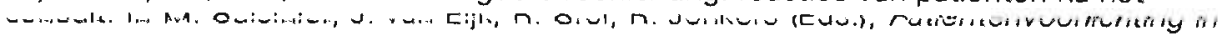
de eerste lijn (pp. 92-100). Den Haag: Care - Uitgeverii voor Gezondheidsbevordering.

Tversky, A., \& Kahneman, D. (1974). Judgment under uncertainty: Heuristics and biases. Science, 185, 1124-1131.

Ware, J.E., \& Hays, R.D. (1988). Methods for measuring patient satisfaction with specific medical encounters. Medical Care, 26, 393-402.

Westhead, J. (1985). Frequent attenders in general practice: Medical, psychological and social characteristics. Journal of the Royal College of General Practitioners, 35, 337-340.

Zee, J., van der. (1982). De vraag naar diensten van de huisarts. Dissertatie. Maastricht: Rijksuniversiteit Limburg. 


\section{ANNEX 2 QUESTIONNAIRE I}

The questionnaire the respondents received before consultation, with the percentages and absolute numbers (in parentheses) of respondents which choose for each answer possibility. 
We would like to ask for your cooperation, while you are waiting, in a study conducted by the department of Health Education of the University of Limburg in Maastricht.

The main focus of this study is the GP consultation itself.

We would like to ask you to answer a number of questions regarding your consultation of the $G P$.

It is important that you answer the questions as sincerely as possible.

In addition we ask you not to discuss the questions with the other persons in the waiting room.

Your information will be kept strictly confidential and anonymous and will be used only for statistical research purposes in this study.

Take your time to read the instructions and the questions carefully before answering the questions.

However, do not take too much time over the questions.

It will take about 10 minutes to fill in the questionnaire.

If you have any questions you can ask for me. I will stay in the waiting room.

We would like to know which complaint you have decided to consult the GP about at this moment. Can you describe your complaint?

If you have more than one complaint, describe the most important complaint.

I have decided to consult the GP about the following complaint:

You can answer the following questions on the next page.

All the questions concern the complaint you just have described above.

While answering the questions, think only about this complaint. 
$N=1000$. complaints, of which 27 were not coded because the description was too vague.

Before you answer the following questions, here is an example.

What do you think of waiting a long time in the GP's waiting room?

1 very pleasant

2 pleasant

3 not pleasant / not unpleasant

4 unpleasant

5 very unpleasant

6 I do not know

You should circle the answer that applies to you most.

If you think that waiting long is unpleasant, you can circle the figure 4 ('unpleasant').

What do you think of waiting a long time in the waiting room of the GP?

1 very pleasant

2 pleasant

3 not pleasant / not unpleasant

4 unpleasant

5 very unpleasant

6 I do not know

If you really cannot answer a question you can circle the figure 6 ("I do not know").

First we would like to know some more about your most important complaint.

You can circle the answer or fill in your answer on the dotted lines.

Only when it is clearly mentioned, should you circle more than one answer. 


\section{Have you had this complaint before?}

$\begin{array}{ll}16.7 \%(167) & 1 \text { yes, once } \\ 46.7 \%(467) & 2 \text { yes, several times } \\ 36.6 \%(366) & 3 \text { no }\end{array}$

2 For how long has this complaint been bothering you?

.. day(s) or .. weeks or ... months.

$\begin{array}{ll}23.3 \%(223) & <1 \text { week } \\ 23.1 \%(231) & \geq 1 \text { week } \leq \leq 2 \text { weeks } \\ 25.3 \%(340) & >2 \text { weeks }-\leq 3 \text { months } \\ 15.4 \%(154) & >3 \text { months }-\leq 1 \text { year } \\ 13.9 \%(139) & >1 \text { year }\end{array}$

3 Have you tried something to treat this complaint?

You can give more than one answer!

$\begin{array}{ll}14.9 \%(149) & 1 \text { no } \\ 33.6 \%(336) & 2 \text { yes, by waiting if it disappears by itself } \\ 18.0 \%(180) & 3 \text { yes, with home remedies } \\ 13.0 \%(130) & 4 \text { yes, with medicine available over the counter } \\ 04.8 \%(048) & 5 \text { yes, by discussing the complaint with others } \\ 28.0 \%(280) & 6 \text { yes, I am already being treated for this complaint } \\ 03.7 \%(037) & 7 \text { yes, by alternative medicine } \\ 10.0 \%(100) & 8 \text { other, ..................................................... }\end{array}$

4 Are you aware of the cause of this complaint?

$\begin{array}{ll}13.5 \%(135) & 1 \text { yes, very well aware } \\ 14.4 \%(144) & 2 \text { yes, well aware } \\ 22.7 \%(227) & 3 \text { unsure } \\ 20.2 \%(202) & 4 \text { no, not aware } \\ 12.4 \%(124) & 5 \text { no, totally unaware } \\ 16.8 \%(168) & 6 \text { I do not know }\end{array}$

The next questions still concern your most important complaint which you decided to consult the GP about.

Read every question very carefully before answering. 
5 Do you think your complaint is serious?
$07.5 \%(075)$
1 yes, very serious
$28.6 \%(286)$
2 yes, serious
$31.7 \%(317)$
3 maybe / maybe not
$22.9 \%(229)$
4 no, not serious
$02.5 \%(025)$
5 no, not serious at all
$06.8 \%(068)$
6 I do not know

\section{Do you think your complaint has to do with a serious disease?}

$\begin{array}{ll}00.7 \%(007) & 1 \text { yes, most certainly } \\ 25.0 \%(250) & 2 \text { yes, certainly } \\ 14.5 \%(145) & 3 \text { maybe / maybe not } \\ 45.9 \%(459) & 4 \text { no } \\ 04.8 \%(248) & 5 \text { no, certainly not } \\ 11.6 \%(116) & 6 \text { I do not know }\end{array}$

7 Do you think the GP can treat your complaint?

$\begin{array}{ll}17.9 \%(179) & 1 \text { yes, most certainly } \\ 30.6 \%(306) & 2 \text { yes, certainly } \\ 32.4 \%(324) & 3 \text { maybe / maybe not } \\ 08.3 \%(083) & 4 \text { no } \\ 02.7 \%(027) & 5 \text { no, certainly not } \\ 08.1 \%(081) & 6 \text { I do not know }\end{array}$

8 Do you think that you could have treated your complaint yourself?

$00.4 \%(004)$

$02.1 \%(021)$

$14.4 \%(144)$

$47.7 \%(477)$

$28.7 \%(287)$

$06.7 \%(067)$
1 yes, most certainly

2 yes, certainly

3 maybe / maybe not

4 no

5 no, certainly not

6 I do not know

9 Do you think you know enough about your complaint?

$\begin{array}{ll}06.4 \%(064) & 1 \text { yes, more than enough } \\ 27.7 \%(277) & 2 \text { yes, enough } \\ 11.1 \%(111) & 3 \text { not enough / not too little } \\ 39.3 \%(393) & 4 \text { no, too little } \\ 10.5 \%(105) & 5 \text { no, far too little } \\ 05.0 \%(050) & 6 \text { I do not know }\end{array}$


10 Do you need more information about your complaint?

$\begin{array}{ll}33.5 \%(335) & 1 \text { yes, most certainly } \\ 41.7 \%(417) & 2 \text { yes, certainly } \\ 06.9 \%(069) & 3 \text { maybe / maybe not } \\ 15.0 \%(150) & 4 \text { no } \\ 01.0 \%(010) & 5 \text { no, certainly not } \\ 01.9 \%(019) & 6 \text { I do not know }\end{array}$

11 Did people advise you to consult the GP?

$36.4 \%$ (36.)

$63.6 \%(636)$

1 yes

2 no, continue with question 13 !

12 Did this advice influence your decision to consult the GP?

$\begin{array}{ll}25.8 \%(094) & 1 \text { yes, very much } \\ 36.8 \%(134) & 2 \text { yes, much } \\ 12.1 \%(044) & 3 \text { maybe / maybe not } \\ 19.2 \%(070) & 4 \text { no, hardly } \\ 05.5 \%(020) & 5 \text { no, hardly at all } \\ 00.5 \%(002) & 6 \text { I do not know }\end{array}$

13 Do you know someone with the same complaint?
$26.2 \%$ (262)
$73.8 \%(738)$
1 yes
2 no, continue with question 18 !

14 Did this person consult the GP for this complaint?
$70.2 \%(184)$
1 yes
$08.4 \%(022)$
2 no, continue with question 18 !
$21.4 \%(056)$
3 I do not know, continue with question 18 !

15 Did the decision of this person to consult the GP influence your decision?

$\begin{array}{ll}09.8 \%(018) & 1 \text { yes, very much } \\ 18.5 \%(034) & 2 \text { yes, much } \\ 08.7 \%(016) & 3 \text { maybe / maybe not } \\ 33.7 \%(062) & 4 \text { no, hardly } \\ 28.8 \%(053) & 5 \text { no, hardly at all } \\ 00.5 \%(001) & 6 \text { I do not know }\end{array}$




\section{Has this person been treated for this complaint by the GP?}

$\begin{array}{ll}79.3 \%(146) & 1 \text { yes } \\ 12.0 \%(022) & 2 \text { no } \\ 08.7 \%(016) & 3 \text { I do not know, continue with question } 18 \text { ! }\end{array}$

17 Did the result of the treatment of this person influence your decision?

$\begin{array}{ll}08.9 \%(015) & 1 \text { yes, very much } \\ 23.2 \%(039) & 2 \text { yes, much } \\ 08.3 \%(014) & 3 \text { maybe / maybe not } \\ 33.3 \%(056) & 4 \text { no, hardly } \\ 25.0 \%(042) & 5 \text { no, hardly at all } \\ 01.2 \%(002) & 6 \text { l do not know }\end{array}$

18 Did you receive information from the media about your complaint?

$08.1 \%(081)$

$91.9 \%(919)$
1 yes

2 no, continue with question 20 !

19 Did this information influence your decision?

$13.6 \%(011)$

$17.3 \%(014)$

$11.1 \%(009)$

$32.1 \%(026)$

$25.9 \%(021)$

$00.0 \%(000)$
1 yes, very much

2 yes, much

3 maybe / maybe not

4 no, hardly

5 no, hardly at all

6 I do not know

20 Do you feel uncertain or certain about your health at this moment?

$04.5 \%(045)$

$22.1 \%(221)$

$34.7 \%(347)$

$26.7 \%(267)$

$07.7 \%(077)$

$04.3 \%(043)$
1 I feel very uncertain

2 I feel uncertain

3 I do not feel uncertain but also not certain

4 I feel certain

5 I feel very certain

6 I do not know

21 Do you feel anxious or assured about your health at this moment?

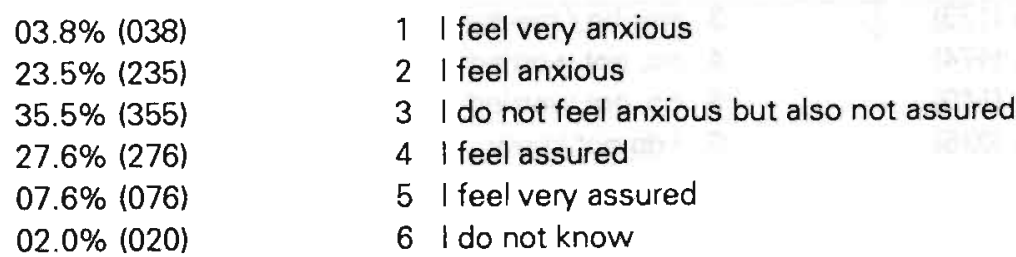



your complaint?

If so, you can write them down here. $(25.9 \% \quad N=259)$

Now some questions about your worry.

The questions still concern your most important complaint at this moment.

1 Are you worried by the complaint itself?

$\begin{array}{ll}05.5 \%(055) & 1 \text { yes, very worried } \\ 35.6 \%(356) & 2 \text { yes, worried } \\ 12.4 \%(124) & 3 \text { maybe / maybe not } \\ 35.7 \%(357) & 4 \text { no, not worried } \\ 09.8 \%(098) & 5 \text { no, not worried at all } \\ 01.0 \%(010) & 6 \text { I do not know }\end{array}$

2 Are you worried by the idea of consulting the GP about your complaint?

$\begin{array}{ll}01.9 \%(019) & 1 \text { yes, very worried } \\ 12.2 \%(122) & 2 \text { yes, worried } \\ 08.5 \%(085) & 3 \text { maybe / maybe not } \\ 55.1 \%(551) & 4 \text { no, not worried } \\ 20.8 \%(208) & 5 \text { no, not worried at all } \\ 01.5 \%(015) & 6 \text { l do not know }\end{array}$

3 Are you worried by the possible diagnosis of your complaint?

$\begin{array}{ll}02.9 \%(029) & 1 \text { yes, very worried } \\ 14.8 \%(148) & 2 \text { yes, worried } \\ 17.3 \%(173) & 3 \text { maybe / maybe not } \\ 47.4 \%(474) & 4 \text { no, not worried } \\ 14.0 \%(140) & 5 \text { no, not worried at all } \\ 03.6 \%(036) & 6 \text { I do not know }\end{array}$




\section{Did you discuss your complaint with other people?}
$59.0 \%(590)$
1 yes
$41.0 \%(410)$
2 no, continue with question 8 !

5. Are you worried by what these people said about your complaint?
$01.7 \%(010)$
$10.0 \%(059)$
1 yes, very worried
$10.2 \%(060)$
2 yes, worried
$55.4 \%(327)$
3 maybe / maybe not
$21.9 \%(129)$
4 no, not worried
$00.8 \%(005)$
5 no, not worried at all
6 I do not know
6
$00.5 \%(003)$
$04.4 \%(026)$
1 yes, very worried
$05.9 \%(035)$
2 yes, worried
$60.3 \%(356)$
3 maybe / maybe not
$27.3 \%(161)$
4 no, not worried
$01.5 \%(009)$
5 no, not worried at all
6 I do not know

Are you worried by what these people said about the idea of consulting the GP?

7

Are you worried by what these people said about the possible diagnosis of your complaint?

$00.7 \%(004)$

$08.5 \%(050)$

1 yes, very worried

$09.5 \%(056)$

2 yes, worried

$57.1 \%(337)$

3 maybe / maybe not

$21.7 \%(128)$

4 no, not worried

$02.5 \%(015)$

5 no, not worried at all

6 I do not know

8 Did you receive information from the media about your complaint?
$08.1 \%(081)$
1 yes
$91.9 \%(919)$
2 no, continue with question 11 ! 


$\begin{array}{ll}04.9 \%(004) & 1 \text { yes, very worried } \\ 18.5 \%(015) & 2 \text { yes, worried } \\ 13.6 \%(011) & 3 \text { maybe / maybe not } \\ 48.1 \%(039) & 4 \text { no, not worried } \\ 14.8 \%(012) & 5 \text { no, not worried at all } \\ 00.0 \%(000) & 6 \text { I do not kno }\end{array}$

10 Are you worried by this information about the possible diagnosis of your complaint?

$\begin{array}{ll}06.2 \%(005) & 1 \text { yes, very worried } \\ 18.5 \%(015) & 2 \text { yes, worried } \\ 11.1 \%(009) & 3 \text { maybe / maybe not } \\ 46.9 \%(038) & 4 \text { no, not worried } \\ 14.8 \%(012) & 5 \text { no, not worried at all } \\ 02.5 \%(002) & 6 \text { I do not know }\end{array}$

11 Are you worried by some other things?

If so, you can write it down here. $(15,9 \% \quad N=159)$

This was the last question.

Can you check all questions?

Did you fill in the questions you had to answer?

Did you miss a page by accident?

We would like to give you a second questionnaire later on.

This questionnaire can be filled in at home.

If you hand in this questionnaire, you will receive the second questionnaire.

MANY THANKS 


\section{ANNEX 3 QUESTIONNAIRE II}

The questionnaire the respondents received after consultation, with the percentages and absolute numbers (in parentheses) of respondents which choose for each answer possibility. 
Now you have consulted the GP, we would like to ask you some questions about this consultation.

The questions concern the complaint you described in the first questionnaire, in the waiting room.

If you have any questions, when answering the questionnaire, you can reach me at home in the evening at the following telephone number: 04754 - 85254 (Angelique van de Kar).

Your information will be kept strictly confidential and anonymous and will be used only for statistical research purposes in this study.

Your GP will not receive this questionnaire, just like the first one.

It is important that you answer the questions as sincerely as possible and that you answer all questions and send back this questionnaire.

Take your time to fill in this questionnaire, you will have a week to send this questionnaire back. You do not have to start immediately.

Read the instructions and the questions carefully before answering the questions.

Before you answer the following questions, here is an example.

\section{What do you think of filling in questionnaires?}
1 very pleasant
2 pleasant
3 not pleasant / not unpleasant
4 unpleasant
5 very unpleasant
6 I do not know

You should circle the answer that applies to you most

If you think that filling in questionnaires is pleasant, you can circle the figure 2 ('pleasant').

\section{What do you think of filling in questionnaires?}

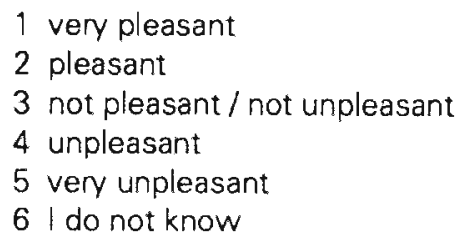

If you really cannot answer a question, you can circle the figure 6 ('I do not know'). 
We would like to ask you some questions about the consultation with the GP.

The next questions concern the complaint you described in the first questionnaire.

This complaint was:

Read the instructions and questions carefully before answering the questions.

$N=791$ complaints

1 Did you have the opportunity to ask all the questions you had about your complaint?

$35.4 \%(280) \quad 1$ yes, more than enough

$58.4 \%(462) \quad 2$ yes, enough

$03.5 \%(028) \quad 3$ not enough / not too little

$01.9 \%(015) \quad 4$ no, too little

$00.6 \%(005) \quad 5$ no, far too little

$00.1 \%(001) \quad 6$ I do not know

2 Was there enough time to discuss your complaint?

$32.2 \%(255)$

$61.1 \%(483)$

$03.5 \%(028)$

$01.8 \%(014)$

$00.8 \%(006)$

$00.6 \%(005)$
1 yes, more than enough

2 yes, enough

3 not enough / not too little

4 no, too little

5 no, far too little

6 I do not know

3 Could you make clear which complaint you consulted the GP for?

$35.9 \%(284)$

$60.7 \%(480)$

$02.0 \%(016)$

$01.0 \%(008)$

$00.1 \%(001)$

$00.3 \%(002)$
1 yes, more than enough

2 yes, enough

3 not enough / not too little

4 no, too little

5 no, far too little

6 I do not know 


\section{Did you have the opportunity to discuss your uncertainty about your health}

with the GP?

You only have to answer when you really felt uncertain at that time! $(N=437)$

$\begin{array}{ll}21.5 \%(094) & 1 \text { yes, more than enough } \\ 61.1 \%(267) & 2 \text { yes, enough } \\ 07.3 \%(032) & 3 \text { not enough / not too little } \\ 04.6 \%(020) & 4 \text { no, too little } \\ 02.1 \%(009) & 5 \text { no, far too little } \\ 03.4 \%(015) & 6 \text { I do not know }\end{array}$

5 Did you have the opportunity to discuss your anxiety about your health with the GP?

You only have to answer when you really felt anxious at that time! $(\mathrm{N}=414)$

$\begin{array}{ll}20.8 \%(086) & 1 \text { yes, more than enough } \\ 57.7 \%(239) & 2 \text { yes, enough } \\ 11.8 \%(049) & 3 \text { not enough / not too little } \\ 04.8 \%(020) & 4 \text { no, too little } \\ 01.4 \%(006) & 5 \text { no, far too little } \\ 03.4 \%(014) & 6 \text { I do not know }\end{array}$

6 If necessary, did the GP give you information about the causes of your complaint?

$\begin{array}{ll}21.5 \%(170) & 1 \text { yes, more than enough } \\ 57.4 \%(454) & 2 \text { yes, enough } \\ 09.7 \%(077) & 3 \text { not enough / not too little } \\ 05.9 \%(047) & 4 \text { no, too little } \\ 02.0 \%(016) & 5 \text { no, far too little } \\ 03.4 \%(027) & 6 \text { | do not know }\end{array}$

7 Did the GP give you information about your complaint itself?

$\begin{array}{ll}20.0 \%(158) & 1 \text { yes, more than enough } \\ 60.1 \%(475) & 2 \text { yes, enough } \\ 09.6 \%(076) & 3 \text { not enough / not too little } \\ 06.6 \%(052) & 4 \text { no, too little } \\ 01.4 \%(011) & 5 \text { no, far too little } \\ 02.4 \%(019) & 6 \text { l do not know }\end{array}$


8 Did the GP give you information about the diagnosis of your complaint?

$\begin{array}{ll}16.7 \%(132) & 1 \text { yes, more than enough } \\ 58.3 \%(461) & 2 \text { yes, enough } \\ 11.6 \%(092) & 3 \text { not enough / not too little } \\ 06.4 \%(051) & 4 \text { no, too little } \\ 02.0 \%(016) & 5 \text { no, far too little } \\ 04.9 \%(039) & 6 \text { ldo not know }\end{array}$

9 Did the GP give you information about the treatment of your complaint?

$\begin{array}{ll}20.7 \%(164) & 1 \text { yes, more than enough } \\ 61.8 \%(489) & 2 \text { yes, enough } \\ 08.5 \%(067) & 3 \text { not enough / not too little } \\ 04.6 \%(036) & 4 \text { no, too little } \\ 02.0 \%(016) & 5 \text { no, far too little } \\ 02.4 \%(019) & 6 \text { I do not know }\end{array}$

10 Did filling in the first questionnaire influence the questions you asked the GP during the consultation?
$01.5 \%(012)$
$06.8 \%$ (054)
1 yes, very much
$11.8 \%(093)$
2 yes, much
$30.3 \%(240)$
3 maybe / maybe not
$44.4 \%(351)$
4 no, hardly
$05.2 \%(041)$
5 no, hardly at all
6 I do not know

11 During the consultation with the GP, did you discuss any other important aspects?

If so, you can write them here down here. $(27.3 \% \quad N=216)$

After your consultation of the GP we would like to know if anything changed in the answers to the questions about your complaint.

Therefore we will ask some questions about your complaint, for which you consulted the GP about, again. 
Read every question very carefully and circle the figure of the answer that now, after the consultation of the GP, applies to you most.

1

Do you now think your complaint is serious?

$02.7 \%(021)$

$18.3 \%(145)$

1 yes, very serious

$23.0 \%(182)$

2 yes, serious

$40.2 \%(318)$

$13.3 \%(105)$

3 maybe / maybe not

$02.5 \%(020)$

4 not, not serious

5 no, not serious at all

6 I do not know

2 Do you now think your complaint has to do with a serious disease?

$\begin{array}{ll}00.9 \%(007) & 1 \text { yes, most certainly } \\ 01.8 \%(014) & 2 \text { yes, certainly } \\ 10.6 \%(084) & 3 \text { maybe / maybe not } \\ 39.2 \%(310) & 4 \text { no } \\ 43.2 \%(342) & 5 \text { no, certainly not } \\ 04.3 \%(034) & 6 \text { I do not know }\end{array}$

3 Do you now think the GP can treat your complaint?

$19.0 \%(150) \quad 1$ yes, most certainly

$27.8 \%(220) \quad 2$ yes, certainly

$25.3 \%(200) \quad 3$ maybe / maybe not

$15.9 \%(126) \quad 4$ no

$06.7 \%(053) \quad 5$ no, certainly not

$05.3 \%(042) \quad 6$ I do not know

4 Do you now think that you could have treated your complaint yourself?

$01.3 \%(010)$

$05.6 \%(044)$

$16.3 \%(129)$

1 yes, most certainly

$41.3 \%(327)$

2 yes, certainly

$32.5 \%(257)$

3 maybe / maybe not

$03.0 \%(024)$

4 no

5 no, certainly not

6 I do not know

5 Do you think you now know enough about your complaint?

$17.1 \%(135)$

$49.4 \%(391)$

$13.7 \%(108)$

$13.1 \%(104)$

$04.8 \%(038)$

$01.9 \%(015)$
1 yes, more than enough

2 yes, enough

3 not enough / not too little

4 no, too little

5 no, far too little

6 I do not know 


\section{Do you now need more information about your complaint?}

$\begin{array}{ll}11.1 \%(088) & 1 \text { yes, most certainly } \\ 22.5 \%(178) & 2 \text { yes certainly } \\ 16.4 \%(130) & 3 \text { maybe / maybe not } \\ 39.6 \%(313) & 4 \text { no } \\ 07.8 \%(062) & 5 \text { no, certainly not } \\ 02.5 \%(020) & 6 \text { I do not know }\end{array}$

7 Do you now feel uncertain or certain about your health?
$01.9 \%(015)$
$08.5 \%(067)$
1 I feel very uncertain
$32.4 \%(256)$
2 I feel uncertain
$40.5 \%(320)$
3 I do not feel uncertain but also not certain
$13.4 \%(106)$
4 I feel certain
$03.4 \%(027)$
5 I feel very certain
6 I do not know

8 Do you now feel anxious or assured about your health?
$01.0 \%(008)$
$08.2 \%(065)$
1 | feel very anxious
$31.5 \%(249)$
2 | feel anxious
$42.4 \%(335)$
3 I do not feel anxious but also not assured
$14.4 \%(114)$
$02.5 \%(020)$
4 I feel assured
5 I feel very assured
6 I do not know

9

Are you now worried by the complaint itself?
$02.1 \%(017)$
$10.2 \%(081)$
$15.3 \%(121)$
$49.6 \%(392)$
$21.2 \%(168)$
$01.5 \%(012)$
1 yes, very worried
2 yes, worried
3 maybe / maybe not
4 no, not worried
5 no, not worried at all
6 I do not know

10 Are you now worried by the consultation of the GP?
$00.4 \%(003)$
$03.8 \%(030)$
1 yes, very worried
$06.8 \%(054)$
2 yes, worried
$55.8 \%$ (441)
3 maybe / maybe not
$31.9 \%(252)$
4 no, not worried
$01.4 \%(011)$
5 no, not worried at all
6 I do not know 


\section{Are you now worried by the diagnosis of your complaint?}

$00.5 \%(004)$

$07.1 \%(056)$

$15.0 \%(119)$

$48.7 \%(385)$

$23.8 \%(188)$

$04.9 \%(039)$
1 yes, very worried

2 yes, worried

3 maybe / maybe not

4 no, not worried

5 no, not worried at all

6 I do not know

We would like to ask you some questions about reasons that maybe have hindered you consulting the GP the last time you had a complaint.

Read every question very carefully and circle the figure of the answer that applies to you most.

1 Was it easy, concerning time, to consult the GP?

$30.1 \%(238)$

$40.8 \%(323)$

$15.3 \%(121)$

$09.9 \%(078)$

$03.7 \%(029)$

$00.3 \%(002)$
1 yes, very easy

2 yes, easy

3 not easy but also not difficult

4 no, difficult

5 no, very difficult

6 I do not know

\section{Was it easy, concerning transport, to consult the GP?}

$50.8 \%(401)$

$39.9 \%(316)$

$05.8 \%(046)$

$01.5 \%(012)$

$01.3 \%(010)$

$00.8 \%(006)$
1 yes, very easy

2 yes, easy

3 not easy but also not difficult

4 no, difficult

5 no, very difficult

6 I do not know

Did you consider the costs of a consultation of the GP?

$03.3 \%(026)$

$12.1 \%(096)$

$07.3 \%(058)$

$36.0 \%(285)$

$37.8 \%(299)$

$03.4 \%(027)$
1 yes, very much

2 yes, much

3 maybe / maybe not

4 no, hardly

5 no, hardly at all

6 I do not know

4 Was it easy, concerning the costs, to consult the GP?

$33.4 \%(264)$
$44.9 \%(355)$
$12.8 \%(101)$
$01.4 \%(011)$
$00.4 \%(003)$
$07.2 \%(057)$

1 yes, very easy

2 yes, easy

3 not easy but aiso not difficult

4 no, difficult

5 no, very difficult

6 I do not know 


\section{Did other factors hinder you consulting the GP about your complaint?}

If so, you can write them down here. $(14.7 \% \quad N=116)$

People have sometimes complaints (like headache, tiredness, injuries, insomnia), which they will not consult the GP about everytime.

We would like to know for which complaints you will NOT consult the GP.

Would you therefore consider carefully if you had or have a complaint which bothers you, but you did not mention this complaint the last time you consulted the GP.

If you have more than one complaint, describe only the most important complaint.

I have the following complaint, which I did NOT consult the GP about and which I do not intend to consult the GP about:

You can answer the questions on the following page.

Al! the questions concern the complaint you just have described above.

So consider only this complaint when answering the questions.

$N=453$. complaints, of which 3 were not coded because the description was too vague. 
First we would like to know some more about your most important complaint.

You can circle the answer or fill in your answer on the dotted lines.

Only when it is clearly mentioned, should you circle more than one answer.

1 Have you had this complaint, for which you do NOT consult the GP, before?

$\begin{array}{ll}06.4 \%(029) & 1 \text { yes, once } \\ 83.0 \%(376) & 2 \text { yes, several times } \\ 00.6 \%(048) & 3 \text { no }\end{array}$

2 For how long has this complaint bothering you?

.. day(s) or . . weeks or . . months.
$18.3 \%(080)$
$<1$ week
$13.0 \%(057)$
$\geq 1$ week $-\leq 2$ weeks
$17.8 \%(078)$
$>2$ weeks - $\leq 3$ months
$17.6 \%(077)$
$33.3 \%(146)$
$>3$ months - $\leq 1$ year
$>1$ year

\section{Have you tried something to treat this complaint?}

You can give more than one answer!
$07.4 \%(048)$
1 no
$27.4 \%(179)$
2 yes, by waiting if it disappears by itself
$17.2 \%(112)$
3 yes, with home remedies
$16.2 \%(106)$
4 yes, with medicine available over the counter
$04.4 \%(029)$
5 yes, by discussing the complaint with others
$08.4 \%(055)$
6 yes, I am already being treated for this complaint
$06.6 \%(043)$
7 yes, by alternative medicine
$12.4 \%(081)$
8 other,

4

Are you aware of the cause of this complaint?
$\begin{array}{ll}17.4 \%(079) & 1 \text { yes, very well aware } \\ 24.7 \%(112) & 2 \text { yes, well aware } \\ 29.6 \%(134) & 3 \text { unsure } \\ 12.8 \%(058) & 4 \text { no, not aware } \\ 08.6 \%(039) & 5 \text { no, totally unaware } \\ 06.8 \%(031) & 6 \text { I do not know }\end{array}$

The next questions still concern your most important complaint which you did NOT consulted the GP about. 
Read every question very carefully and circle the figure of the answer that applies to you most.

\section{Do you think your complaint is serious?}

$02.6 \%(012)$

$13.2 \%(060)$

$28.0 \%(127)$

$42.2 \%(191)$

$10.2 \%(046)$

$03.8 \%(017)$
1 yes, very serious

2 yes, serious

3 maybe / maybe not

4 no, not serious

5 no, not serious at all

6 I do not know

6 Do you think your complaint has to do with a serious disease?
$00.7 \%(003)$
$01.1 \%(005)$
1 yes, most certainly
$09.3 \%(042)$
$42.6 \%(193)$
2 yes, certainly
$41.1 \%(186)$
3 maybe / maybe not
$05.3 \%(024)$
4 no
5 no, certainly not
6 I do not know

7 Do you think the GP can treat your complaint?
$04.4 \%(020)$
$14.6 \%(066)$
1 yes, most certainly
$33.1 \%(150)$
2 yes, certainly
$26.5 \%(120)$
3 maybe / maybe not
$13.7 \%(062)$
4 no
$07.7 \%(035)$
5 no, certainly not
6 I do not know

8 Do you think that you could have treated your complaint yourself?

$\begin{array}{ll}08.6 \%(039) & 1 \text { yes, most certainly } \\ 19.2 \%(087) & 2 \text { yes, certainly } \\ 29.6 \%(134) & 3 \text { maybe / maybe not } \\ 23.8 \%(108) & 4 \text { no } \\ 11.0 \%(050) & 5 \text { no, certainly not } \\ 07.7 \%(035) & 6 \text { I do not know }\end{array}$

9 Do you think you know enough about your complaint?

$\begin{array}{ll}10.8 \%(049) & 1 \text { yes, more than enough } \\ 36.0 \%(163) & 2 \text { yes, enough } \\ 19.0 \%(086) & 3 \text { maybe / maybe not } \\ 23.0 \%(104) & 4 \text { no, too little } \\ 06.8 \%(031) & 5 \text { no, very too little } \\ 04.4 \%(020) & 6 \text { I do not know }\end{array}$


10 Do you need more information about your complaint?
$14.6 \%(066)$
$27.6 \%(125)$
1 yes, most certainly
$20.3 \%(092)$
2 yes, certainly
$29.4 \%(133)$
3 maybe / maybe not
$04.4 \%(020)$
4 no
$03.8 \%(017)$
5 no, certainly not
6 I don not know

\section{Did people advise you NOT to consult the GP?}

$03.1 \%(014)$

$96.9 \%(439)$

1 yes

2 no, continue with question 13 !

12 Did this advice influence your decision NOT to consult the GP?

$21.4 \%(003)$

$07.1 \%(001)$

1 yes, very much

$28.6 \%(004)$

2 yes, much

$21.4 \%(003)$

3 maybe / maybe not

$07.1 \%(001)$

4 no, hardly

$14.3 \%(002)$

5 no, hardly at all

6 I do not know

13 Do you know someone with the same complaint?
$42.4 \%(192)$
$57.6 \%(261)$
1 yes
2 no, continue with question 18 !

14 Did this person consult the GP for this complaint?

$42.7 \%(082)$

$32.3 \%(062)$

1 yes

$25.0 \%(048)$

2 no, continue with 18 !

3 I do not know, continue with question 18 !

15 Did the decision of this person, to consult the GP, influence your decision?

$01.2 \%(001)$

$04.9 \%(004)$

$11.0 \%(009)$

$30.5 \%(025)$

$51.2 \%(042)$

$01.2 \%(001)$
1 yes, very much

2 yes, much

3 maybe / maybe not

4 no, hardly

5 no, hardly at all

6 I do not know

16 Has this person been treated for this complaint by the GP?
$74.4 \%(061)$
$12.2 \%(010)$
1 yes
$13.4 \%(011)$
2 no
3 I do not know, continue with question 18 ! 
$04.2 \%(003)$

$09.9 \%(007)$

$11.3 \%(008)$

$28.2 \%(020)$

$45.1 \%(032)$

$01.4 \%(001)$
1 yes, very much

2 yes, much

3 maybe / maybe not

4 no, hardly

5 no, hardly at all

6 I do not know

18 Did you receive information from the media about your complaint?

$19.0 \%(086)$

$81.0 \%(367)$
1 yes

2 no, continue with question 20 !

\section{Did this information influence your decision?}

$02.3 \%(002)$

$11.6 \%(010)$

$17.4 \%(015)$

$34.9 \%(030)$

$32.6 \%(028)$

$01.2 \%(001)$
1 yes, very much

2 yes, much

3 maybe / maybe not

4 no, hardly

5 no, hardly at all

6 I do not know

20 Do you feel uncertain or certain about your health at this moment?

$02.6 \%(012)$

$09.1 \%(041)$

$35.8 \%(162)$

$36.0 \%(163)$

$12.6 \%(057)$

$04.0 \%(018)$
1 I feel very uncertain

2 I feel uncertain

3 I do not feel uncertain but also not certain

4 I feel certain

5 I feel very certain

6 I do not know

21 Do you feel anxious or assured about your health at this moment?
$02.4 \%(011)$
1 I feel very anxious
$06.6 \%(030)$
2 I feel anxious
$34.0 \%(154)$
3 I do not feel anxious but also not assured
$41.5 \%(188)$
4 I feel assured
$11.9 \%(054)$
5 I feel very assured
$03.5 \%(016)$
6 I do not know 

your complaint?

If so, you can write them down here. $(30.7 \% \quad N=139)$

Now some questions about your worry.

The questions still concern your most important complaint which you did NOT consult the GP about.

\section{Are you worried by the complaint itself?}

$\begin{array}{ll}02.4 \%(011) & 1 \text { yes, very worried } \\ 12.4 \%(056) & 2 \text { yes, worried } \\ 13.7 \%(062) & 3 \text { maybe / maybe not } \\ 50.6 \%(229) & 4 \text { no, not worried } \\ 18.5 \%(084) & 5 \text { no, not worried at all } \\ 02.4 \%(011) & 6 \text { I do not know }\end{array}$

2 Are you worried by the idea of NOT consulting the GP about your complaint?

$00.7 \%(003)$

$04.4 \%(020)$

$10.2 \%(046)$

$57.2 \%(259)$

$22.3 \%(101)$

$05.3 \%(024)$
1 yes, very worried

2 yes, worried

3 maybe / maybe not

4 no, not worried

5 no, not worried at all

6 I do not know

3 Are you worried by the possible diagnosis of your complaint?

$01.1 \%(005)$

$07.9 \%(036)$

$14.6 \%(066)$

$51.4 \%(233)$

$21.6 \%(098)$

$03.3 \%(015)$
1 yes, very worried

2 yes, worried

3 maybe / maybe not

4 no, not worried

5 no, not worried at all

6 I do not know 


\section{Did you discuss your complaint with other people?}

$55.2 \%(250)$

$44.8 \%(203)$
1 yes

2 no, continue with question 8 !

5 Are you worried by what these people said about your complaint?

$\begin{array}{ll}00.8 \%(002) & 1 \text { yes, very worried } \\ 03.6 \%(009) & 2 \text { yes, worried } \\ 10.0 \%(025) & 3 \text { maybe / maybe not } \\ 61.6 \%(154) & 4 \text { no, not worried } \\ 20.4 \%(051) & 5 \text { no, not worried at all } \\ 03.6 \%(009) & 6 \text { I do not know }\end{array}$

$6 \quad$ Are you worried by what these people said about the idea of NOT consulting the GP?

$\begin{array}{ll}00.4 \%(001) & 1 \text { yes, very worried } \\ 02.8 \%(007) & 2 \text { yes, worried } \\ 07.2 \%(008) & 3 \text { maybe / maybe not } \\ 58.0 \%(145) & 4 \text { no, not worried } \\ 24.8 \%(062) & 5 \text { no, not worried at all } \\ 06.8 \%(017) & 6 \text { I do not know }\end{array}$

$7 \quad$ Are you worried by what these people said about the possible diagnosis of your complaint?

$\begin{array}{ll}00.4 \%(001) & 1 \text { yes, very worried } \\ 04.4 \%(011) & 2 \text { yes, worried } \\ 06.4 \%(016) & 3 \text { maybe / maybe not } \\ 61.2 \%(153) & 4 \text { no, not worried } \\ 22.4 \%(056) & 5 \text { no, not worried at all } \\ 05.2 \%(013) & 6 \text { I do not know }\end{array}$

8 Did you receive information from the media about your complaint?

$19.0 \%(086)$

1 yes

$81.0 \%(367)$

2 no, continue with question 11 ! 
$9 \quad$ Are you worried by this information about your complaint?

$\begin{array}{ll}02.3 \%(002) & 1 \text { yes, very worried } \\ 05.8 \%(005) & 2 \text { yes, worried } \\ 09.3 \%(008) & 3 \text { maybe / maybe not } \\ 48.8 \%(042) & 4 \text { no, not worried } \\ 32.6 \%(028) & 5 \text { no, not worried at all } \\ 01.2 \%(001) & 6 \text { ldo not know }\end{array}$

10 Are you worried by this information about the possible diagnosis of your complaint?

$\begin{array}{ll}02.3 \%(002) & 1 \text { yes, very worried } \\ 08.1 \%(007) & 2 \text { yes, worried } \\ 44.2 \%(038) & 4 \text { no, not worried } \\ 31.4 \%(027) & 5 \text { no, not worried at all } \\ 03.5 \%(003) & 6 / \text { do not know }\end{array}$

11 Are you worried by some other things?

If so, you can write them down here. $(11.3 \% \quad N=51)$ 
We would like to ask you some questions about complaints in general.

1 Have you ever thought that, for particular complaints, your GP could not help you and that nevertheless you still consulted the GP about your complaint?
$21.9 \%(173)$
$66.5 \%(526)$
1 yes
$11.6 \%(092)$
2 no, continue with question 3 !
3 I do not know, continue with question 3 !

If so, can you describe these complaints briefly? $(21.9 \% \quad N=173)$

\section{Can you circle in the following list why you DID consult the GP after all?}

You can give more than one answer!

I DID consult the GP because:

$12.1 \%(054) \quad 1$ I thought the complaint was serious

$04.9 \%(022) \quad 2$ I thought the complaint did concern a serious disease

$17.9 \%(080) \quad 3$ I needed more information about the complaint

$21.0 \%(094) \quad 4$ l could not treat the complaint by myself

$08.3 \%(037) \quad 5$ other persons advised me to consult the GP

$01.1 \%(005) \quad 6$ someone, with the same complaint, consulted the GP

$00.9 \%(004) \quad 7$ someone, with the same complaint, was treated by the GP

$02.9 \%(013) \quad 8$ I heard, saw, or read something about the complaint

$10.1 \%(045) \quad 9$ I thought the GP could remove my uncertainty

$12.5 \%(056) \quad 10$ I wanted to be reassured by my GP

$08.3 \%(037) \quad 11$ other,

3 Have you ever thought that, for particular complaints, your GP could help you but that nevertheless you decided NOT to consult the GP about this complaint?

$16.6 \%(131)$

$69.5 \%(550)$

$13.9 \%(110)$
1 yes

2 no, continue on page 22 !

3 i do not know, continue on page 22 !

If so, can you describe these complaints briefly? $(16.6 \% \quad N=131)$ 


\section{Can you circle in the following list why you did NOT consult the GP after all?}

You can give more than one answer!

I did NOT consult the GP because:

\begin{tabular}{|c|c|}
\hline $21.6 \%(070)$ & 1 I thought the complaint was not \\
\hline $07.4 \%(024)$ & 2 I thought the complaint did not concern a serious disease \\
\hline $08.3 \%(027)$ & 3 I had enough information about the \\
\hline $23.8 \%(077)$ & 4 I could treat the complaint by \\
\hline $00.0 \%(000)$ & 5 other persons advised me not to consult the \\
\hline $01.5 \%(005)$ & 6 someone, with the same complaint, did not consult the GP \\
\hline $00.6 \%(002)$ & 7 someone, with the same complaint, was not treated \\
\hline $02.2 \%(007)$ & 8 I heard, saw, or read something about this \\
\hline $12.0 \%(039)$ & 9 I was not uncertain about my \\
\hline $14.2 \%(046)$ & 10 I was not anxious about my \\
\hline $08.3 \%(027)$ & 11 other, \\
\hline
\end{tabular}

For this study we need some general background information.

You can circle your answer and where possible describe the answer on the dotted line.

1 For how long have you been consulting the same GP?

\pm .. months or . . year. (Missing $N=26$ )

$05.8 \%(044)$

$29.3 \%(224)$

$<1$ year

$20.0 \%(153)$

1 - 5 years

$26.8 \%(205)$

6 - 10 years

$18.2 \%(139)$

11 - 20 years

$>20$ years

2 How often did you consult the GP last year? (including home calls)?

\pm . times. (Missing $\mathrm{N}=23$ )

$\begin{array}{lr}03.8 \%(029) & 0 \text { times } \\ 70.8 \%(544) & 1-5 \text { times } \\ 18.4 \%(141) & 6-10 \text { times } \\ 07.0 \%(054) & >10 \text { times }\end{array}$


3 When did you last consult the GP? (or when did the GP last visit you at home?)

$\pm \ldots$ day(s) or .. weeks or .. months ago. (Missing $N=34$ )

$\begin{array}{ll}25.1 \%(190) & <1 \text { week } \\ 16.4 \%(124) & \geq 1 \text { week }-\leq 2 \text { weeks } \\ 29.9 \%(226) & >2 \text { weeks }-\leq 3 \text { months } \\ 22.2 \%(168) & >3 \text { months } \leq 1 \text { year } \\ 06.5 \%(049) & >1 \text { year }\end{array}$

4 Do you feel healthy, compared to other persons of the same age?

$\begin{array}{ll}10.0 \%(079) & 1 \text { yes, very healthy } \\ 44.0 \%(348) & 2 \text { yes, healthy } \\ 26.0 \%(206) & 3 \text { maybe / maybe not } \\ 09.5 \%(075) & 4 \text { no, unhealthy } \\ 01.4 \%(011) & 5 \text { no, very unhealthy } \\ 09.1 \%(072) & 6 \text { I do not know }\end{array}$

\section{$5 \quad$ What do you do first when you are not feeling too well?}

You can give more than one answer!

$08.8 \%(114)$

$37.7 \%(489)$

$16.7 \%(216)$

$11.3 \%(146)$

$05.8 \%(075)$

$14.6 \%(189)$

$01.7 \%(022)$

$03.5 \%(045)$
1 nothing

2 wait until it disappears by itself

3 use home remedies

4 buy medicine over the counter

5 discuss it with other persons

6 consult the GP about

7 visit alternative medicine

8 other,

$6 \quad$ Are you male or female?

$40.6 \%(321)$

$59.4 \%(470)$

2 female 


\section{$7 \quad$ What is your age?}

. year

$25.0 \%(198)$

$21.3 \%(168)$

$19.9 \%(158)$

$14.3 \%(113)$

$11.4 \%(090)$

$08.1 \%(064)$ $\leq 25$ year

$>25$ - 35 year

$>36-45$ year

$>46-55$ year

$>56-65$ year

$\geq 65$ year

\section{What is your marital status?}

(Missing $\mathrm{N}=1$ )

$25.3 \%(200)$

$04.9 \%(039)$

$60.5 \%(478)$

$04.8 \%(038)$

$04.4 \%(035)$
1 unmarried

2 living with someone

3 married

4 widowed

5 divorced

9 What is your highest education?
$00.3 \%(002)$
$14.3 \%(113)$
1 none
$22.6 \%$ (179)
2 elementary school
$19.3 \%(153)$
3 lower vocational training
$05.3 \%(042)$
4 lower secondary schools
$20.1 \%(159)$
5 secondary schools
$05.8 \%(046)$
6 secondary vocational training
$10.4 \%(082)$
7 high school
$01.9 \%(015)$
$00.0 \%(000)$
8 higher vocational training
9 college
10 other,

\section{What is your occupation at this moment?}
$25.4 \%(201)$
$03.0 \%(024)$
1 housewife / houseman
$12.1 \%(096)$
2 voluntary work
$35.4 \%(280)$
3 student
$08.8 \%(070)$
4 full time job (paid)
$01.4 \%(011)$
5 part time job (paid)
$01.0 \%(008)$
6 registered for employment, for less than one year
$05.7 \%(045)$
7 registered for employment, for more than one year
$07.1 \%(056)$
$00.0 \%(000)$
8 disabled
9 retired
10 other, 
11 What is your insurance?

$70.9 \%(558)$

$29.1 \%(229)$

1 public

2 private

12 What is your net income per month (including the income of your partner)?

(Missing $\mathrm{N}=133$ )

$\begin{array}{ll}10.3 \%(068) & 1 \text { less than } f 1000 \\ 16.4 \%(108) & 2 \text { between } f 1000 \text { and } f 1500 \\ 22.0 \%(145) & 3 \text { between } f 1500 \text { and } f 2000 \\ 18.2 \%(120) & 4 \text { between } f 2000 \text { and } f 2500 \\ 08.5 \%(056) & 5 \text { between } f 2500 \text { and } f 3000 \\ 08.1 \%(053) & 6 \text { between } f 3000 \text { and } f 3500 \\ 06.8 \%(045) & 7 \text { between } f 3500 \text { and } f 4000 \\ 09.6 \%(063) & 8 \text { more than } f 4000\end{array}$

13 When did you fill in this questionnaire?

Date :

This was the last question.

Can you check all questions?

Did you fill in the questions you had to answer?

Did you not miss a page by accident?

Did you fill in today's date?

You can use the enclosed envelope to send back this questionnaire.

You do not need a stamp and it can put in every post box.

You will be a great help in our study if you fill in and send back this questionnaire as well.

\section{MANY THANKS}




\section{CURRICULUM VITAE}

Angélique van de Kar, born in Echt on Octobre 2nd in 1961, remained her province Limburg unintentionally loyal. After finishing Atheneum in 1981 she started her studies Health Sciences at the University of Limburg in Maastricht. In 1985 she graduated in Health Education, one of the specializations of Health Sciences. Specific attention was paid to the health education part for schools and patient education for hospitals. But this path changed when she started at the Department of Health Education with a research project. No longer education had priority but research of determinants of consulting the general practitioner. Educational aspirations were found in skills-trainings, introduction programmes and informative missions for (becoming) Health Sciences students.

Since september 1989 another challenge has been found, after a scientific period. She became health educator of the Public Health Department of Midden-Limburg. Contacts with general practitioners are still very important but research results have to be translated into practical interventions. Now, as head of the Department of Health Education of the Public Health Department, she is occupied with priorities concerning prevention and their translation into internal and external Health Education interventions. 
